\title{
Stratigraphy and palaeontology of the lower Miocene Kiel Sand Member (Berchem Formation) in temporary exposures in Antwerp (northern Belgium)
}

\author{
Stijn EVERAERT ${ }^{1 *}$, Dirk K. MUNSTERMAN ${ }^{2}$, PieTER J. DE SCHUTTER ${ }^{3}$, MARK BOSSELAERS ${ }^{4}$, Jeroen VAN BOECKEL ${ }^{5}$, \\ GUNTHER CLEEMPUT ${ }^{6} \&$ TACO J. BOR ${ }^{7}$
}

${ }_{1}^{1}$ Kapelleommegang 54, 9310 Herdersem (Aalst), Belgium; stijn.everaert1@gmail.com.

${ }^{2}$ TNO - Geological Survey of the Netherlands, P.O. Box 80015, 3508 TA Utrecht, the Netherlands; dirk.munsterman@tno.nl.

${ }^{3}$ Royal Belgian Institute of Natural Sciences, dept. of Palaeontology, volunteer scientific collaborator, Vautierstraat 29, 1000 Brussels,Belgium; somniosus@skynet.be.

${ }^{4}$ Royal Belgian Institute of Natural Sciences, dept. of Palaeontology, volunteer scientific collaborator, Vautierstraat 29, 1000 Brussels, Belgium; Koninklijk Zeeuwsch Genootschap der Wetenschappen, PO Box 378, 4330 AJ Middelburg, the Netherlands; mark.bosselaers@telenet.be.

${ }^{5}$ Lange Molenstraat 22, 2220 Heist-op-den-Berg, Belgium; jeroen.vb@telenet.be.

${ }^{6}$ Van Cauwelaertstraat 7, Ternat, Belgium; gunthercleemput@hotmail.com.

${ }^{7}$ Prinsenweer 54, 3363 JK Sliedrecht, the Netherlands; tacobor@xs4all.nl.

*orresponding author.

\begin{abstract}
The stratigraphic position of the lower Miocene Kiel Sand Member of the Berchem Formation in the Antwerp area (northern Belgium) is not well constrained and its depositional environments are poorly known. Due to a spatial limited decalcification front, the Kiel Sand Member is completely decalcified in southern Antwerp and gradually becomes fossiliferous to the north-east of the city. The stratigraphy and palaeontology of the fossiliferous sediments in three temporary exposures are presented. The dinoflagellate cyst analysis of fossiliferous horizons shows the relative progress of a transgression in the southern North Sea Basin during the early-middle Burdigalian, that probably initiated in the late Aquitanian. The Kiel Sand Member contains an important mollusc fauna, with several species reported for the first time from this member. The taphonomy and fauna of the shell beds indicate a shallow marine, high energetic depositional environment, strongly influenced by storms, currents, waves and a rather low sedimentation rate. The climate was warm-temperate to subtropical. In all studied sections, the Kiel Sand Member could be clearly distinguished from the Antwerpen Sand Member: similarities and differences are discussed. Moving to the north of Antwerp, the erosive base of the Antwerpen Sand Member cuts deeper into the Kiel Sand Member. The Early Miocene Unconformity (EMU) is suggested at this contact.
\end{abstract}

KEYWORDS: Aquitanian, Burdigalian, dinoflagellate cysts, Mollusca, Elasmobranchii, taphonomy, North Sea Basin.

\section{Introduction}

Miocene fossils have been recorded for nearly two centuries in temporary excavations in and around the city of Antwerp (Fig. 1) (e.g. Nyst \& Westendorp, 1839; Van Beneden, 1865; Le Hon, 1871; Leriche, 1926). Since the lower-middle Miocene Berchem Formation is present in the subsurface of the city area, this sequence is well accessible in temporary construction pits for geological research. Three members were defined by De Meuter \& Laga (1976), from bottom to top: Edegem Sand Member, Kiel Sand Member and Antwerpen Sand Member. The Edegem and Antwerpen Sand Members are highly fossiliferous and during the last century, the palaeontology of both members has been systematically studied (e.g. Glibert, 1945; Glibert, 1952; Van der Mark, 1965; Janssen \& Van der Mark, 1968; Marquet, 1991; Vervoenen, 1995; Lambert, 2004; Louwye et al., 2010; De Schutter, 2011; Hoedemakers \& Dufraing, 2018). In contrast, the fossil record of the Kiel Sand Member, which represents an extensive time interval between the Edegem and Antwerpen Sand Members, is poorly known. The relatively minor palaeontological attention for the Kiel Sand Member is caused by (1) the large-scale decalcification of the Kiel Sand Member in southern Antwerp (De Meuter \& Laga, 1976; Louwye et al., 2000) and (2) the fact that the more northern located, fossiliferous sediments are only occasionally accessible in large temporary excavations due to their lower position in the subsurface of Antwerp. The scarce research discussed several marine invertebrates found in the Deurganckdok Sandstone Bed at the Deurganckdok near Doel (BGD 014E0283, DOV TO20011001) (Herman \& Marquet, 2007). More recently, the fossiliferous Kiel Sand Member was studied by Everaert et al. (2019) with an overview of the elasmobranch fauna and accompanying fossils from a single horizon at the temporary Post X section, and by De Schutter \& Everaert (2020, this volume) at the temporary Argenta section (Fig. 1; see 3.1.), where an $8 \mathrm{~m}$ thick sequence of the Kiel Sand Member was exposed with several fossil-bearing horizons. In this study, the stratigraphy of a third temporary exposure of the Kiel Sand Member, the Tweelingenstraat section (Fig. 1; see 3.1.), is described. The stratigraphic and palaeontological differences between the Argenta section and both the Post $\mathrm{X}$ and Tweelingenstraat sections are discussed. The Argenta section can be regarded as a reference succession since it holds the most complete sequence of the Kiel Sand Member. A dinoflagellate cysts analysis is carried out to assess the relative dating and the correlation of several characteristic, fossiliferous horizons. The stratigraphy and fossil content of the Kiel Sand Member in its type area are further discussed.

\section{Geological background}

After the deposition of the marine Rupelian sequence in northern Belgium, the tectonic uplift (Savian Phase) of the Brabant and Ardennes areas during the late Oligocene caused regression in the southern North Sea area (Vandenberghe et al., 1998). Deposition of marine sediments recommenced during the early Miocene in the northern and north-eastern part of the Flemish Region. During the Burdigalian, a marine transgression invaded the region from a north-north-west direction (Louwye, 2005) which resulted in the deposition of the glauconitic, shallow marine sands of the Berchem Formation. However, Munsterman \& Deckers (2020, this volume) even reported Aquitanian deposits in the Campine area (Borehole ON-Mol-1, DOV ON-Mol-1; Borehole Weelde, DOV kb8d8e-B161). In the Antwerp city area, the Berchem Formation unconformably overlies the Rupelian Boom Formation. The partly coeval Bolderberg Formation was deposited in the east of the country and represents the transition between the open marine Berchem Formation and the continental influenced Ville Formation (Deckers \& Louwye, 2019). 

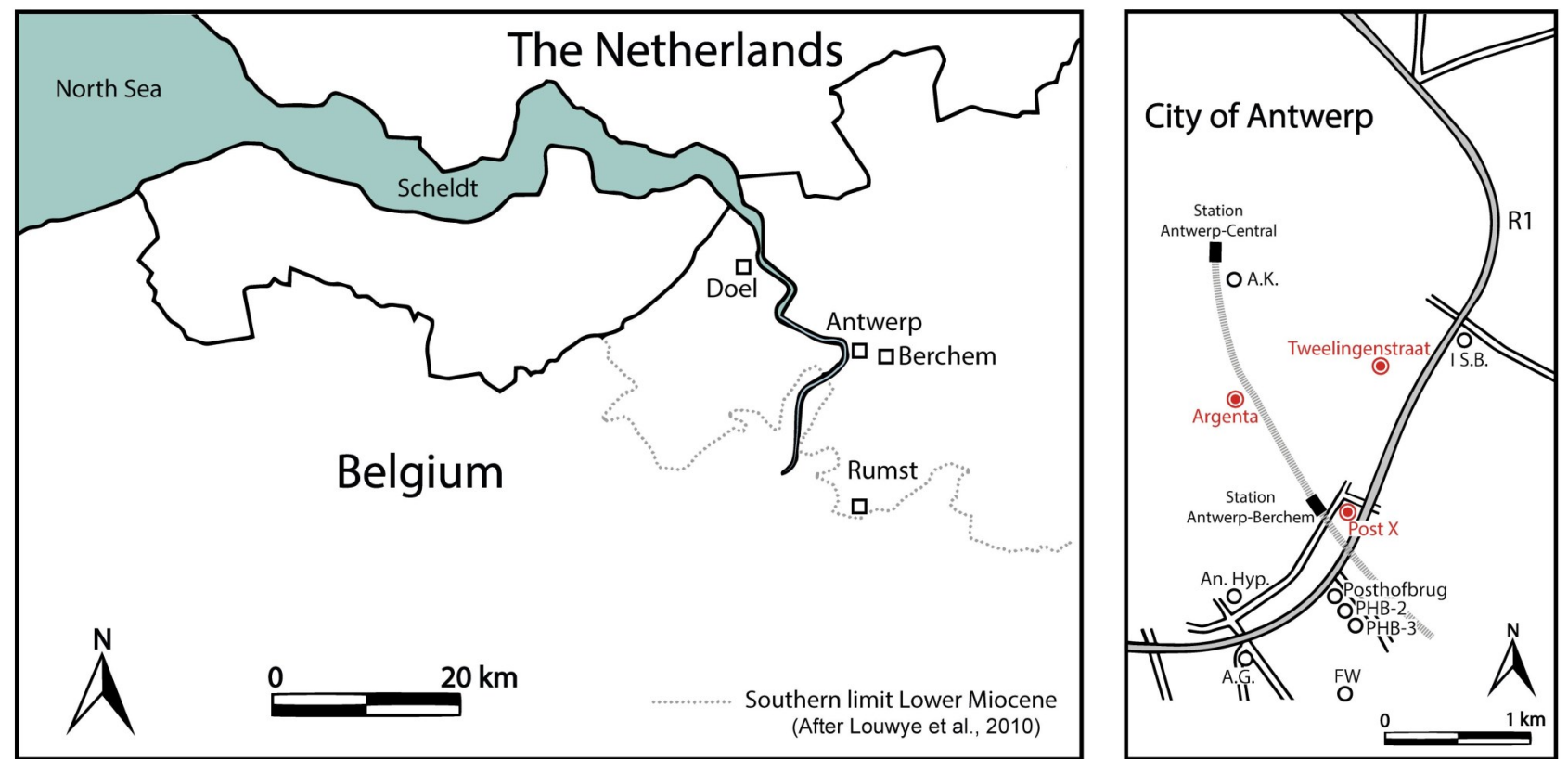

Figure 1. Map of the Antwerp area in northern Belgium (left) and location of the study area in Antwerp (right). An overview of the discussed temporary exposures can be found at https://www.dov.vlaanderen.be/data/opdracht/2020-023193.

Minor attention was paid to the stratigraphy of the Berchem Formation until the early 20th century and the numerous recovered fossils were referred to the "Antwerpian", a regional stage introduced by Cogels in Van Ertborn (1879), but nowadays abandoned (Laga et al., 2006). Glibert (1958) recognized two units in the Antwerpian, the "Sables d'Edegem à Panopea menardi" and the "Sables d'Anvers à Glycymeris deshayesi et à Chlamys ercolaniana". The construction of the motorway R1 around Antwerp in the 1960s provided the opportunity to study the lithostratigraphy of the Berchem Formation in detail over a large area (Janssen \& Van der Mark, 1968; Moorkens, 1969; De Meuter et al., 1976). De Meuter \& Laga (1976) formally divided the Berchem Formation in the Antwerp city region into the Edegem Sand Member, the Kiel Sand Member and the Antwerpen Sand Member. The dinoflagellate cyst biostratigraphy of these members was studied by Louwye et al. (2000). An early Burdigalian age was attributed to the Edegem Sand Member and a Burdigalian age to the succeeding Kiel Sand Member (Louwye et al., 2000). After a hiatus near the early-middle Miocene transition in the area of Antwerp city, the Antwerpen Sand Member, characterized by the occurrence of authigenic glauconites and phosphatic levels, was deposited during the Langhian (latest Burdigalian?) middle Serravalian, probably as a result of a new transgressive phase (Louwye et al., 2000, 2010, 2020). The Berchem Formation and its members represent an incomplete sequence with several hiatuses, caused by the continuing tectonic uplift which interacted with fluctuating sea levels to create depositional windows (Vandenberghe et al., 1998). The lithology, stratigraphy and depositional history of the Berchem Formation was recently reviewed by Louwye et al. (2020, this volume).

De Meuter \& Laga (1976) defined the Kiel Sand Member as a grey-green, medium fine- to coarse-grained, loose, very glauconitic sandy unit devoid of fossils, with typical fine, sometimes concentrated, whitish tracks (bioturbation), locally dark brown oxidation bands and concentrations of glauconite, with some rare clay streaks and sandstones. According to De Meuter \& Laga (1976), the Kiel Sand Member is restricted to the central and southern part of the Antwerp agglomeration and becomes fossiliferous to the north and east where "it becomes indistinguishable from the superjacent Antwerpen Sand Member". However, at the northern Argenta section, the fossiliferous Kiel Sand Member could be easily distinguished from the overlying Antwerpen Sand Member based on its different lithology (e.g. lighter colour, coarser grain size, much lower clay content, loose structure, continuous presence of abundant bioturbations in the Kiel Sand Member) (De Schutter \& Everaert, 2020, this volume), which contradicts the observation of De Meuter \& Laga (1976). This clear distinction was also observed in the more eastern located Tweelingenstraat section (see 4.1. and 4.2.). De Schutter \& Everaert (2020, this volume) discussed the formal definition of the Kiel Sand Member and pointed out the need of a redefinition of this member, which is also re-emphasised by Louwye et al. (2020, this volume).

\section{Study area, material and methods}

\subsection{Localities}

The three temporary exposures are located in a small area within the motorway R1, between Berchem, the centre of Antwerp city and the north-eastern border of the Antwerp district (Fig. 1). In this relatively flat area, the boundary between the Antwerpen Sand Member and the Kiel Sand Member is usually situated between c. 6 and 7 metres below surface. To the south, the Kiel Sand Member is devoid of calcareous fossils due to decalcification. To the north, these layers dip further downwards and are no longer accessible in excavations.

The Post X section (BGD 028E0923) (Fig. 2) was located next to the railway station of the Berchem district (Antwerp) with DOV Code TO-20150701 in the NCS Neogene reference set (De Nil et al., 2020, this volume). Ground level at the site is at c. $8.5 \mathrm{~m}$ TAW (Belgian Ordnance Level). A section of c. $8 \mathrm{~m}$ was exposed in 2015 during the excavation works for new office buildings between the Binnensingel, the Borsbeeksebrug and the motorway R1 (WGS84 coordinates 51.198833, 4.435139). The stratigraphy of the section was described in detail by Everaert et al. (2019).

The Argenta section (BGD 028W1004) (Fig. 2) was located in the city centre of Antwerp (Antwerp district) with DOV Code TO-20190417 in the NCS Neogene reference set (De Nil et al., 


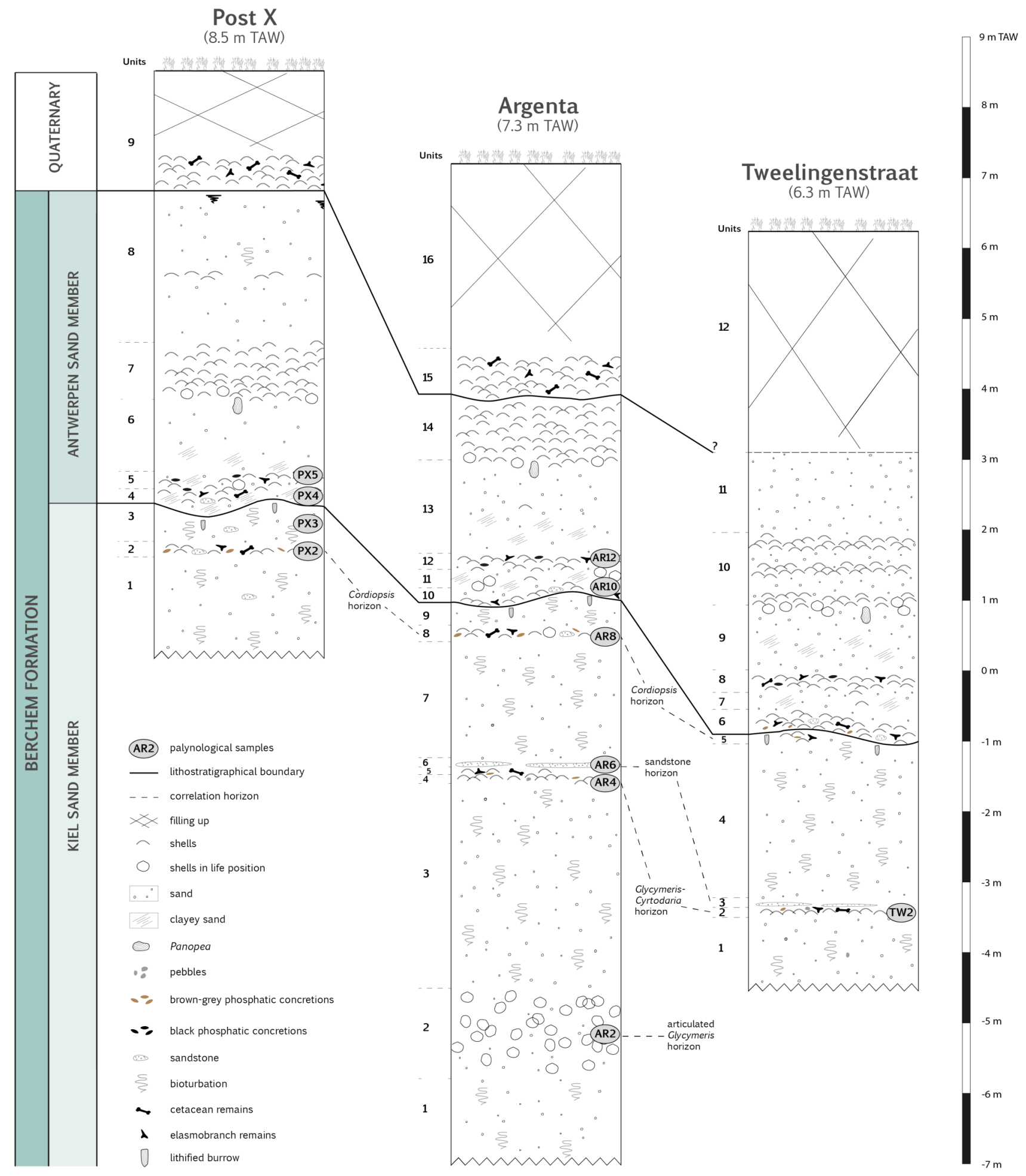

Figure 2. Lithology and lithostratigraphy of the Post X (after Everaert et al., 2019), Argenta (after De Schutter \& Everaert, 2020) and Tweelingenstraat (this study) sections. The unit numbers of the first two sections are copied from the original publications; consequently, these numbers do not correspond between the sections.

2020 , this volume). Ground level at the site is at c. $7.3 \mathrm{~m}$ TAW. A section of $15 \mathrm{~m}$ was exposed in 2018-2019 during the excavation for a subterraneous parking lot of the new Argenta building, enclosed by the Van Diepenbeeckstraat and the Lamorinièrestraat (WGS84 coordinates 51.206056, 4.424056). The stratigraphy of this section was described in detail by De Schutter \& Everaert (2020, this volume).

The Tweelingenstraat section (BGD 028E0922) (Fig. 2) was located at the north-eastern border of the Antwerp district with DOV Code TO-20191211 in the NCS Neogene reference set (De Nil et al., 2020, this volume). Ground level at the site is at c. $6.3 \mathrm{~m}$ TAW. During the winter of 2019 , a section of c. $10 \mathrm{~m}$ was exposed for the construction of new apartment buildings for the Zurenborg Poort project, enclosed by the Tweelingenstraat and the Plantin en Moretuslei (WGS84 coordinates 51.208583, 4.436000). The stratigraphy of this section is described in the present paper (see 4.1. and 4.2.).

\subsection{Palynological preparation and analysis}

Eleven sediment samples of each c. $20 \mathrm{~g}$ were selected for palynological analysis. At the Argenta section, the most extensive and complete sequence, six samples were taken from 
the fossiliferous horizons: AR2, AR4, AR6, AR8, AR10 and AR12 (Fig. 2, see also De Schutter \& Everaert, 2020, this volume). Four samples were examined from the Post X section to assess in detail the transition between the Kiel and Antwerpen Sand Members (PX2, PX3, PX4 and PX5: numbers after stratigraphic unit numbers of Everaert et al., 2019). One sample was taken at the Tweelingenstraat section (TW2, from unit 2 in the description below) for comparison with the corresponding horizon at the Argenta section (AR4). All samples, with the exception of AR2, are in situ outcrop samples taken by the first author. Due to strict safety regulations during the excavation of the lowermost metres of the $15 \mathrm{~m}$ deep Argenta construction pit, it was not possible to sample in situ the deepest shell horizon (AR unit 2). However, several articulated Glycymeris valves were collected (by MB) from displaced sediments of this last excavation phase. Sample AR2 was obtained by opening the firmly closed articulated valves of a Glycymeris specimen. By its particular morphology and taphonomy, this articulated Glycymeris very probably originates from Argenta unit 2, being the only horizon containing articulated Glycymeris valves in such large quantities.

The samples were prepared at Palynological Laboratory Services (PLS, UK). The standard sample processing procedures were used, which involves $\mathrm{HCl}$ and $\mathrm{HF}$ treatment to dissolve the carbonates and the silicates, heavy liquid separation $\left(\mathrm{ZnCl}_{2}\right)$ and sieving over an $18 \mu \mathrm{m}$ mesh sieve. The organic residue was mounted with glycerine jelly on microscopic slides. A quantitative palynological analysis was carried out (by DM) at the Geological Survey of the Netherlands (TNO) according to standard procedures (Janssen \& Dammers, 2008). In total, a targeted minimum of c. 200 dinoflagellate cysts, spores and pollen (palynomorphs) was counted. The remainder of the slides were scanned for rare taxa. The number of dinoflagellate cysts, as well as the number of other microfossils (e.g. Botryococcus, chambers of foraminifers, acritarchs, Pediastrum), is shown in the distribution tables (see Tables 2, 3, 4). The First Occurrence Datum (FOD) and Last Occurrence Datum (LOD) of dinoflagellate cysts were used for the age interpretation of the outcrop samples. Species important for stratigraphical and/or sedimentary facies analysis are mentioned in the dedicated section of this paper. The dinoflagellate taxonomy follows Fensome et al. (2019).

The palynological interpretation is based on key references relating to the palynostratigraphy of the Miocene from the North Sea region: Anthonissen (2012), De Schepper \& Head (2008, 2009), Dybkjær \& Piasecki (2010), Köthe (2003, 2007), Köthe et al. (2008), Kuhlmann et al. (2006), Louwye (2000), Louwye et al. (2000), Louwye (2002), Louwye (2005), Louwye et al. (2010), Munsterman \& Brinkhuis (2004), Powell (1992) and Zevenboom (1995). The DN zonation of de Verteuil \& Norris (1996; Maryland \& Virginia, USA) is followed in this study, since it was generally used in Belgium. The zonation is recalibrated to the Geological Time Scale (Ogg et al., 2016) and correlated to the Southern North Sea Miocene (SNSM) zonation of Munsterman \& Brinkhuis (2004) used in the Netherlands (Munsterman et al., 2019) (Fig. 3).

\subsection{Macropalaeontology}

Macrofossils were obtained by combining two methods: (1) large quantities of sediment were sieved through a sieve with a $5 \mathrm{~mm}$ mesh size and residues sorted on site, and (2) bulk samples of sediment were carried home and sieved (dry/wet) through a $1 \mathrm{~mm}$ mesh, after which the residues were sorted for fossils (sampled sediment per horizon for each locality is given in Table 1). Both methods are complementary in order to get a view of the fauna. Decalcification in several of the layers makes calcareous fossils fragile, often causing them to be damaged or destroyed during sample processing. In situ lithifications of the sandstone horizon were studied in detail at the Argenta section. Later, additional large lithifications were collected from displaced sediments of the second excavating phase. The collected lithifications have been solidified to prevent disintegration with an acetone-liquid glue solution, making their colour slightly darker than original.

For the determination of molluscs, standard works on the Miocene of the North Sea Basin were used, such as Glibert (1945, 1952, 1958), Janssen (1984), Herman \& Marquet (2007), Moths et al. (2010) and Stein et al. (2016). We concur with

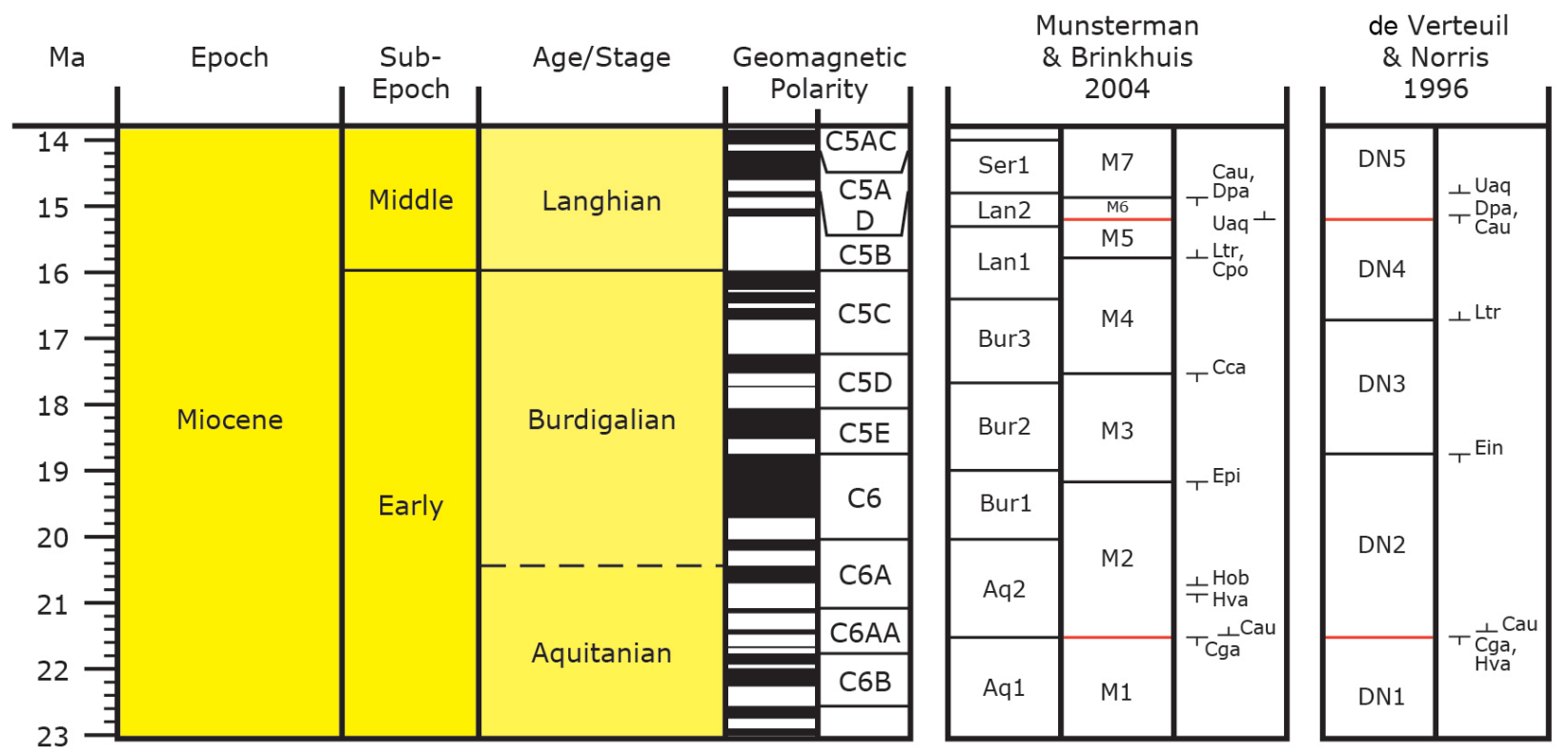

Figure 3. Overview of the early-middle Miocene zonation scheme sensu Munsterman \& Brinkhuis (2004) and de Verteuil \& Norris (1996), recalibrated to the Geological Time Scale of Ogg et al. (2016). In red: correlation lines between both zonation schemes (after Munsterman et al., 2019). The Aquitanian-Burdigalian boundary is indicated with a dashed line, because an official GSSP for the Burdigalian has not yet been assigned. 
Table 1. Sampled sediment per horizon for each locality (litre). * These horizons could only be sampled for a very short time due to the ongoing excavating works and stricter security measures in the deepest section of the pit. ** At the Post X section, this depth was not reached at the time of our study.

\begin{tabular}{|c|c|c|c|c|c|c|}
\hline & \multicolumn{2}{|c|}{ Post $\mathrm{X}$} & \multicolumn{2}{|c|}{ Argenta } & \multicolumn{2}{|c|}{ Tweelingenstraa } \\
\hline & $5 \mathrm{~mm}$ & $1 \mathrm{~mm}$ & $5 \mathrm{~mm}$ & $1 \mathrm{~mm}$ & $5 \mathrm{~mm}$ & $1 \mathrm{~mm}$ \\
\hline Cordiopsis horizon & 15000 & 1500 & 2100 & 300 & 10 & - \\
\hline Sandstone horizon & \multirow{2}{*}{\multicolumn{2}{|c|}{ ** }} & $(*)$ & $(*)$ & $(*)$ & $(*)$ \\
\hline Glycymeris-Cyrtodaria horizon & & & $300(*)$ & $20(*)$ & $100(*)$ & $40(*)$ \\
\hline
\end{tabular}

Louwye et al. (2010) in that Glycymeris baldii Glibert \& Van de Poel, 1965 must be regarded as a separate species instead of a subspecies. However, we do not use the species name Mancosinodia nysti (d'Orbigny, 1852) used in Louwye et al. (2010), instead we prefer Cordiopsis polytropa nysti (d'Orbigny, 1852) following Moerdijk et al. (2010) and Janse \& Langeveld (2014). Dulai (2013), Cadée (1977), Jagt (2016a, b) and Schwarzhans (2010) are used as references for the identification of brachiopods, bryozoans, echinoids, barnacles and fish otoliths. For the systematic descriptions and illustrations of the elasmobranchii, we refer to Reinecke et al. (2011) and Bor et al. (2012).

\subsection{Repositories and abbreviations}

All samples and fossils referred to in this study are curated in one of the following repositories:

RBINS: Royal Belgian Institute of Natural Sciences, Brussels, Belgium. Collection numbers start with IRSNB

NBC: Naturalis Biodiversity Center, Leiden, the Netherlands

TNO-GDN: TNO Geological Survey of the Netherlands, Utrecht, the Netherlands

BGD: Geological Survey of Belgium, Brussels, Belgium

SE: Private collection Stijn Everaert, Aalst, Belgium.

Other abbreviations used:

AR: Argenta temporary exposure

DM: Dirk Munsterman

DOV: Databank Ondergrond Vlaanderen

MB: Mark Bosselaers

PDS: Pieter De Schutter

PX: Post X temporary exposure

TW: Tweelingenstraat temporary exposure.

\section{Tweelingenstraat section}

This section was studied during excavation works on 25.11.2019 and 11.12.2019. Ground level at the site is c. $6.30 \mathrm{~m}$ TAW, the terminal depth of the construction pit was at $10.40 \mathrm{~m}$ below surface. Sediment descriptions have been made in the field, granulometric and mineralogical analyses are not available.

\subsection{Lithology of the Tweelingenstraat section (Fig. 2)}

Lithological and palaeontological description of the observed units, from bottom to top:

Unit 1: $1 \mathrm{~m}$ of grey, rather coarse-grained, loose glauconitic sand with some trace fossils.

Unit 2: Maximum $5 \mathrm{~cm}$ thick horizon consisting of greyish, coarse-grained, glauconitic sand with many valves of Glycymeris baldii with convex up orientation. Cyrtodaria angusta (Nyst \& Westendorp, 1839), Glossus burdigalensis cypriniformis (Nyst in Dewalque, 1868) and Cordiopsis polytropa nysti are common. These molluscs are heavily decalcified and consequently very fragile. Occasionally, rounded brown-grey phosphatic concretions occur, together with some black pebbles and small sandstone fragments. Some well-preserved elasmobranch teeth were encountered.

Unit 3: 1-3 cm thick horizon consisting of discontinued glauconitic sandstone lithifications. These lithifications contain some unidentifiable calcareous fragments of molluscs and many traces of worms at the basal side. A single tooth of Isurus oxyrinchus Rafinesque, 1810 was encountered (Plate 4/2).

Unit 4: Circa $2.3 \mathrm{~m}$ of bioturbated, grey, medium fine- to coarse-grained, glauconitic sand apparently lacking macrofossils. At a single spot, the top of this bed is overlain by unit 5 , otherwise it is truncated by unit 6 . Below the contact with unit 6 , some lithified, large burrows were observed, visible as white tracks.

Unit 5: Maximum $5 \mathrm{~cm}$ thick concentration of some heavily decalcified valves of presumably Cordiopsis polytropa nysti and brown-grey phosphatic concretions. A single shark tooth of Carcharhinus priscus (Agassiz, 1843) was found. This unit was only present at a single spot, elsewhere this layer was reworked in unit 6.

Unit 6: $20 \mathrm{~cm}$ thick shell bed, resting on a maximum $10 \mathrm{~cm}$ thick bed of blackish to dark green, fine-grained, clayey glauconitic sand. The base of this unit is sharp and erosive, and presents an abrupt shift to a finer grain size, a more compact structure and a darker sediment colour. Locally, unit 6 has a moderate undulating appearance due to load casting effects. Few reworked, small flat sandstones occur scattered at the base. The mollusc fauna is dominated by (slightly decalcified) Glycymeris baldii valves, mostly randomly orientated. In the base of the shell bed, articulated specimens are common. Several large, well-preserved specimens of Neopycnodonte navicularis (Brocchi, 1814) are present. Also, some dispersed Cordiopsis polytropa nysti and Patinopecten brummelii (Nyst, 1864) valves are noted. Haustator eryna (d'Orbigny, 1852) is common. Mainly reworked, rather rounded brown-grey phosphatic concretions occur, together with some shark teeth, cetacean remains and a cheloniid plate fragment.

Unit 7: $30-40 \mathrm{~cm}$ blackish to dark green, fine, clayey glauconitic sand with some dispersed valves of Glycymeris baldii.

Unit 8: $20 \mathrm{~cm}$ thick shell bed with blackish to dark green, fine, clayey glauconitic sand packed with valves of Glycymeris baldii. In addition, Cordiopsis polytropa nysti, Patinopecten brummelii, Glossus lunulatus lunulatus (Nyst, 1835) and Haustator eryna are present. Dark green to black phosphatic concretions are characteristic for this horizon. Shark teeth and some cetacean bones are present.

Unit 9: $95 \mathrm{~cm}$ blackish to dark green glauconitic sand with a coarsening upward trend. Macrofossils were not observed, except for rare articulated valves of Panopea kazakovae Glibert 
\& Van de Poel, 1966 in life position in the upper $15 \mathrm{~cm}$.

Unit 10: $95 \mathrm{~cm}$ thick sequence of 3 to 4 massive, separated shell beds (each $15-20 \mathrm{~cm}$ thick) of Glycymeris baldii in a matrix of medium fine, very glauconitic sand. Most disarticulated valves are convex up orientated and densely packed, articulated valves occur at the base of the unit.

Unit 11: At least $1 \mathrm{~m}$ of dark coloured glauconitic sand.

Unit 12: The uppermost c. $3 \mathrm{~m}$ of the Tweelingenstraat section could not be studied due to ongoing progress of the construction works.

\subsection{Comparison of the Tweelingenstraat, Argenta and Post $X$ sections and lithostratigraphic identification of the Kiel Sand Member (Fig. 2)}

In the Tweelingenstraat excavation, as in the other sections, the Kiel Sand Member (units 1-5) can be clearly distinguished from the overlying Antwerpen Sand Member (units 6-11), by a sharp lithological boundary. This boundary is characterized by (1) the clear colour difference, especially visible in dry profiles, between the grey Kiel Sand Member and the darker coloured Antwerpen Sand Member (Fig. 8, see also Everaert et al., 2019, figs 4-5; De Schutter \& Everaert, 2020, this volume, fig. 3), (2) the more loosely compacted, coarser-grained Kiel Sand Member in contrast to the more cohesive fine, clayey and more erosionresistant base of the Antwerpen Sand Member (Fig. 6B, see also Everaert et al., 2019, figs 3-4), (3) the marked load cast effects in the shell bed at the base of the Antwerpen Sand Member (Fig. 7 and discussed in section 7; see also Everaert et al., 2019, figs 6 -7), (4) the continuous presence of bioturbation in the Kiel Sand Member succession (Fig. 10, see De Schutter \& Everaert, 2020, this volume, plate $1 \mathrm{~B}$ ), and (5) the presence of lithified Ophiomorpha burrows just below the boundary (Fig. 6B), visible as frequent, small round whitish tracks in fresh profiles. Hence, both members can be distinguished regardless of the presence or absence of calcareous fossils. At the Tweelingenstraat section, the Kiel Sand Member consists of at least $3.5 \mathrm{~m}$ medium-fine to coarse-grained, grey, loose glauconitic sand with many quartz grains and abundant trace fossils. Only one thin horizon with heavily decalcified molluscs was observed (unit 2). The overlying Antwerpen Sand Member (unit 6-11) has a total thickness of at least $4 \mathrm{~m}$ (upper boundary could not be observed) and consists of dark coloured to black, fine to medium fine-grained, compact, very glauconitic sand with several shell horizons. The molluscs are very well preserved compared to those in the Kiel Sand Member. The Antwerpen Sand Member displays a coarsening upward trend (visually assessed), the basal part is slightly clayey. According to a flushed drilling $80 \mathrm{~m}$ north of the Tweelingenstraat section, "blue clay" is reached at $30.5 \mathrm{~m}$ below surface (DOV 1463B_19_Antwerpen_zurenborg_soiltech). We interpret this clay unit as the top of the Boom Formation. Consequently, the Berchem Formation may continue for another $20 \mathrm{~m}$ below the base of the pit.

Tweelingenstraat unit 1 can be correlated with the uppermost part of Argenta unit 3, hence the articulated Glycymeris horizon (AR unit 2) and the base of the Kiel Sand Member were not reached. Despite similarities between both successions, we also observed some differences.

In the Tweelingenstraat section, the Glycymeris-Cyrtodaria horizon (TW unit 2) is maximum $5 \mathrm{~cm}$ thick and directly overlain by c. $2 \mathrm{~cm}$ thick sandstone lithifications (TW unit 3). At the Argenta site, however, the Glycymeris-Cyrtodaria horizon (AR unit 4) and the sandstone level (AR unit 6), respectively $10-20 \mathrm{~cm}$ and $10-15 \mathrm{~cm}$ thick, are well-developed, highly fossiliferous and separated by up to $5 \mathrm{~cm}$ of rather coarse -grained sand (AR unit 5). In both the Argenta and the Tweelingenstraat sections, the thicknesses of the Glycymeris-
Cyrtodaria horizon and the sandstone bed seem to vary in the same way; therefore, both horizons probably have a related history (see 6.2.). In addition, both levels in the Tweelingenstraat section exhibit a stronger decalcification, complicating the collecting of calcareous fossils.

The Cordiopsis horizon is rarely observed at the top of the Kiel Sand Member in the Tweelingenstraat exposure (TW unit 5). In contrast, at the Argenta and Post $X$ sections, the Cordiopsis horizon is well present, situated at c. $50 \mathrm{~cm}$ below the top of the Kiel Sand Member (AR unit 8, PX unit 2). At the Argenta and Post $X$ sections, it contains a rich fossil elasmobranch fauna and is characterized by the abundance of brown-grey rounded phosphatic concretions (Plate 7/6). However, at the Tweelingenstraat section, the base of the Antwerpen Sand Member has most likely abraded this horizon, as various elements in its basal shell bed (TW unit 6) are reworked from the Cordiopsis horizon, e.g. several brown-grey phosphatic concretions, only sporadically observed at the base of the Antwerpen Sand Member at the Argenta (AR unit 10) and Post X (PX units 4-5) sections.

\section{Palynological results}

\subsection{Argenta section}

The assemblages are very rich in dinoflagellate cysts (marine algae) and bisaccates (gymnosperms). Apart from the bisaccates, other sporomorphs (spores and pollen) are rare to scarce. The variety in dinoflagellate cysts on the contrary is very large. In the lowest samples, in particular AR2 and AR4, Paralecaniella (acritarch or schizosporous algae taxon; Elsik, 1977 ) is also very common. In common numbers, this genus indicates coastal marine conditions. Reworking is relatively rare and mostly has an Eocene to Oligocene origin. The preservation is good to excellent (the latter especially for samples AR10 and AR12).

The palynological analyses indicate the following results for the samples at different levels along the Argenta section (Table 2, see sample positions in Fig. 2):

AR2: the association is dated as late Aquitanian, Zone DN2a (basal Zone SNSM2). The age assessment is based on the LOD's of Ectosphaeridium picenum and Thalassiphora pelagica, Homotryblium vallum (LOD in Aquitanian) and Hystrichokolpoma pseudooceanicum (LOD in Aquitanian; Zevenboom, 1995; Munsterman \& Brinkhuis, 2004; Dybkjær \& Piasecki, 2010). The FOD of Cousteaudinium aubryae confirms an earliest age in the late Aquitanian. Exochosphaeridium insigne is conspicuously absent.

AR4, AR6, and AR8: the LOD's of Cordosphaeridium (= ex Tithyrosphaeridium) cantharellus, Exochosphaeridium insigne and the FOD's of Exochosphaeridium insigne and Sumatradinium hamulatum indicate that the early-middle Burdigalian, Zone DN2b (zones SNSM2-3) is reached. Very limited reworking is present from the Eocene (Membranilarnacia, Rottnestia borussica) and Oligocene (Wetzeliella gochtii and Wetzeliella symmetrica).

AR10 and AR12: the microflora is interpreted as latest Burdigalian-early Langhian, Zone DN4 (zones SNSM56). The dating is based on the LOD's of Apteodinium spiridoides, Cousteaudinium aubryae, Distatodinium paradoxum and the FOD's of Labyrinthodinium truncatum truncatum and Labyrinthodinium truncatum modicum. Sumatradinium druggii is also present in both associations. Cerebrocysta poulsenii occurs in AR12. The relative number of bisaccates is lower than that in the underlying successions. The Spiniferites spp. increased in values, which agrees with the decreased numbers of Paralecaniella, showing a larger open-marine influence. 
Table 2. Results of the palynological analysis of the Argenta section.

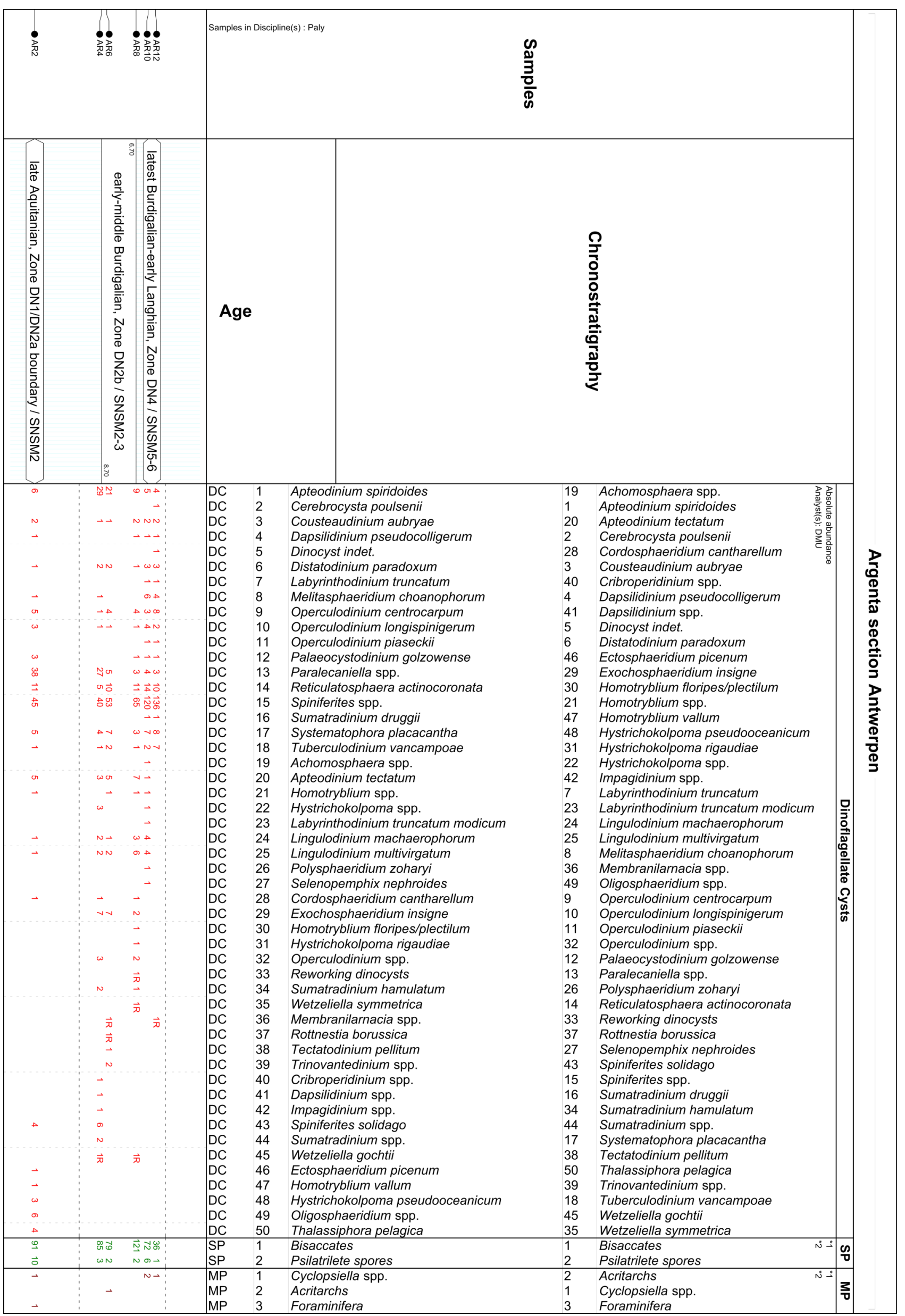




\subsection{Post $X$ section}

Marine dinoflagellate cysts are dominating the associations in the lower samples PX2 and PX3, while bisaccate pollen (gymnosperms) are relatively much more prominent in the palynospectrum of the upper samples PX4 and PX5. Spores are sparsely recorded in the assemblages. The dinoflagellate cysts are very variable in species. The increasing upwards trend in numbers of the open-marine genus Spiniferites, earlier shown in the associations of the Argenta section, is here confirmed. Preservation is good. Reworking is only represented in relatively rare values and in particular with an origin in the Oligocene.

The following results for the palynological analysed samples at different levels along the Post $\mathrm{X}$ section are interpreted (Table 3, see sample positions in Fig. 2):

PX2: the age-assessment of the assemblage is early-middle Burdigalian, Zone DN2b (zones SNSM2-3). The dating is based on the LOD's of Cordosphaeridium (= ex Tithyrosphaeridium) cantharellus, Exochosphaeridium insigne and the FOD's of Exochosphaeridium insigne, Sumatradinium soucouyantae and Cousteaudinium aubryae. Reworking is recorded from the Oligocene (Enneadocysta pectiniformis and Wetzeliella symmetrica) and from the Lower-Middle Jurassic (Nannoceratopsis spp.).

PX3: the FOD of Sumatradinium druggii, the last consistent occurrence in common values of Lingulodinium multivirgatum and the absence of the genus Labyrinthodinium indicate an age interpretation of middle-late Burdigalian, Zone DN3 (Zone SNSM4).

PX4 and PX5: the LOD's of Apteodinium spiridoides, Cousteaudinium aubryae, Distatodinium paradoxum and the FOD of Labyrinthodinium truncatum modicum indicate an age in the latest Burdigalian-early Langhian, Zone DN4 (zones SNSM5-6). Similar trends, like in the Argenta section, develop from Zone DN2 to Zone DN4. Again, the relative numbers of the open-marine genus Spiniferites increases from 42 to $62 \%$ of the total sum of dinocysts and Paralecaniella decreases in values, although less than those in Argenta. Relative differences, not in the trend, but between these numbers could be explained, because the base sample of the latter is relatively older within zone DN2.

\subsection{Tweelingenstraat section}

The palynological slide is very rich in bisaccates (gymnosperms; c. 52\% of the total sum palynomorphs) and marine dinoflagellate cysts $(48 \%)$. Spores are very rarely recorded $(0.45 \%)$. The marine dinoflagellate cysts are very differentiated in species. The largest groups of marine dinoflagellate cysts are: Apteodinium spiridoides, Exochosphaeridium insigne, Reticulosphaera actinocoronata and Spiniferites spp. The preservation is good.

The palynological interpretation of the sample in the Tweelingenstraat, Antwerpen (Table 4, see sample position in Fig. 2):

TW2: the age interpretation of the assemblage is earlymiddle Burdigalian, Zone DN2b (zones SNSM2-3). The dating is based on the LOD's of Cordosphaeridium (= ex Tithyrosphaeridium) cantharellus, Exochosphaeridium insigne and the FOD's of Exochosphaeridium insigne, Sumatradinium hamulatum, Sumatradinium soucouyantae and Cousteaudinium aubryae.

\section{Macrofossils and palaeoenvironment: Kiel Sand Member}

Several fossiliferous horizons were observed in the study area and a synthesis of their general lithology and the taphonomy of their fossil content is presented here. Palaeoenvironments are deduced and discussed.

\subsection{Articulated Glycymeris horizon}

General character. Coarse-grained, grey glauconitic sand with dispersed, articulated valves of Glycymeris baldii in life position. This horizon has a thickness of c. $1.2 \mathrm{~m}$.

Reference sections. Argenta unit 2, depth c. 11.8-13.0 m below surface (De Schutter \& Everaert, 2020, this volume).

Biostratigraphy. Dinocyst biozone DN2a (de Verteuil \& Norris, 1996), basal zone SNSM2 (Munsterman \& Brinkhuis, 2004).

Age. Late Aquitanian (see also 8. General discussion and conclusions).

Palaeontology. Glycymeris baldii dominates the fauna, 9 articulated and 12 disarticulated valves were collected in displaced sediment by MB. Most articulated valves were still firmly closed, even after displacement of the sediment. Several collected specimens are densely encrusted by barnacles (Plate 1/1A-E). The barnacles belong to Balanus (s.s.) aff. stellaris (Brocchi, 1814) (Menesini, 1965; Menesini, 1982; Zullo \& Perreault, 1989; Diedrich, 2012; Buckeridge et al., 2020) (Plate 1/4). The species is reported from the Middle Eocene (France only) to the Pliocene (and possibly also the Pleistocene) of the Mediterranean and Europe (Menesini, 1984; Diedrich, 2012). The sediment within some of the articulated valves yielded additional fossil material: two specimens of Cupuladriidae were discovered and three fragments of the bivalve Laevicardium subturgidum (d' Orbigny, 1852). A single specimen of Hinnites ercolanianus Cocconi, 1873 is recorded in a disarticulated Glycymeris valve (Plate 1/2).

Remarks and discussion. The structure of the articulated Glycymeris horizon could be observed in situ in the cement bentonite hardened sediment walls of the Argenta construction pit, while several articulated Glycymeris valves and other fossils were collected from displaced sediment of this deepest excavating phase.

Although most of the Glycymeris were not encrusted with barnacles, this phenomenon is remarkably common. The frequent appearance of densely barnacle encrusted and Maeandropolydora affected Glycymeris shells has not been reported earlier from the Berchem Formation and is only known from this level in the Kiel Sand Member, which has not been observed before in the Antwerp area. It is lacking in the composite profile of Janssen \& Van der Mark (1968) and in the Kievitstraat/Ploegstraat (A.K.) section (BGD 028W0399, DOV kb15d28w-B453), which was not deep enough (Van den Bosch, 1966; De Meuter et al., 1976).

Palaeoenvironment. The majority of Glycymeris shells is present as articulated valves in life position (Plate 1/1E), scattered in a matrix of glauconitic sand. There is no indication of concentration or reworking by currents or waves in this horizon.

On 16 of 21 inspected Glycymeris specimens, a subtriangular corner of the posterior side was covered with densely packed barnacle shells. Many of these barnacle shells are filled with 
Table 3. Results of the palynological analysis of the Post X section.

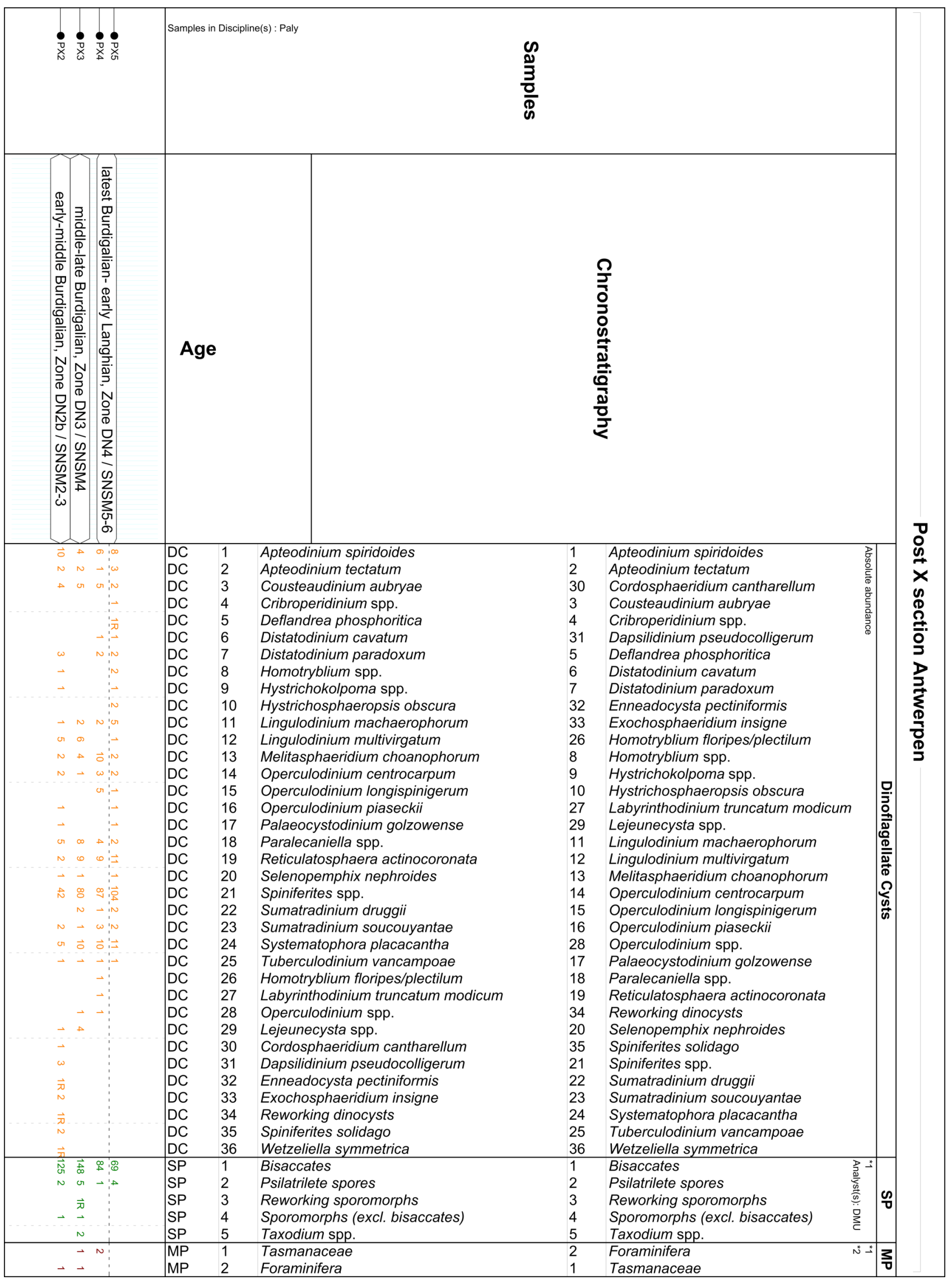


Table 4. Results of the palynological analysis of the Tweelingenstraat section.

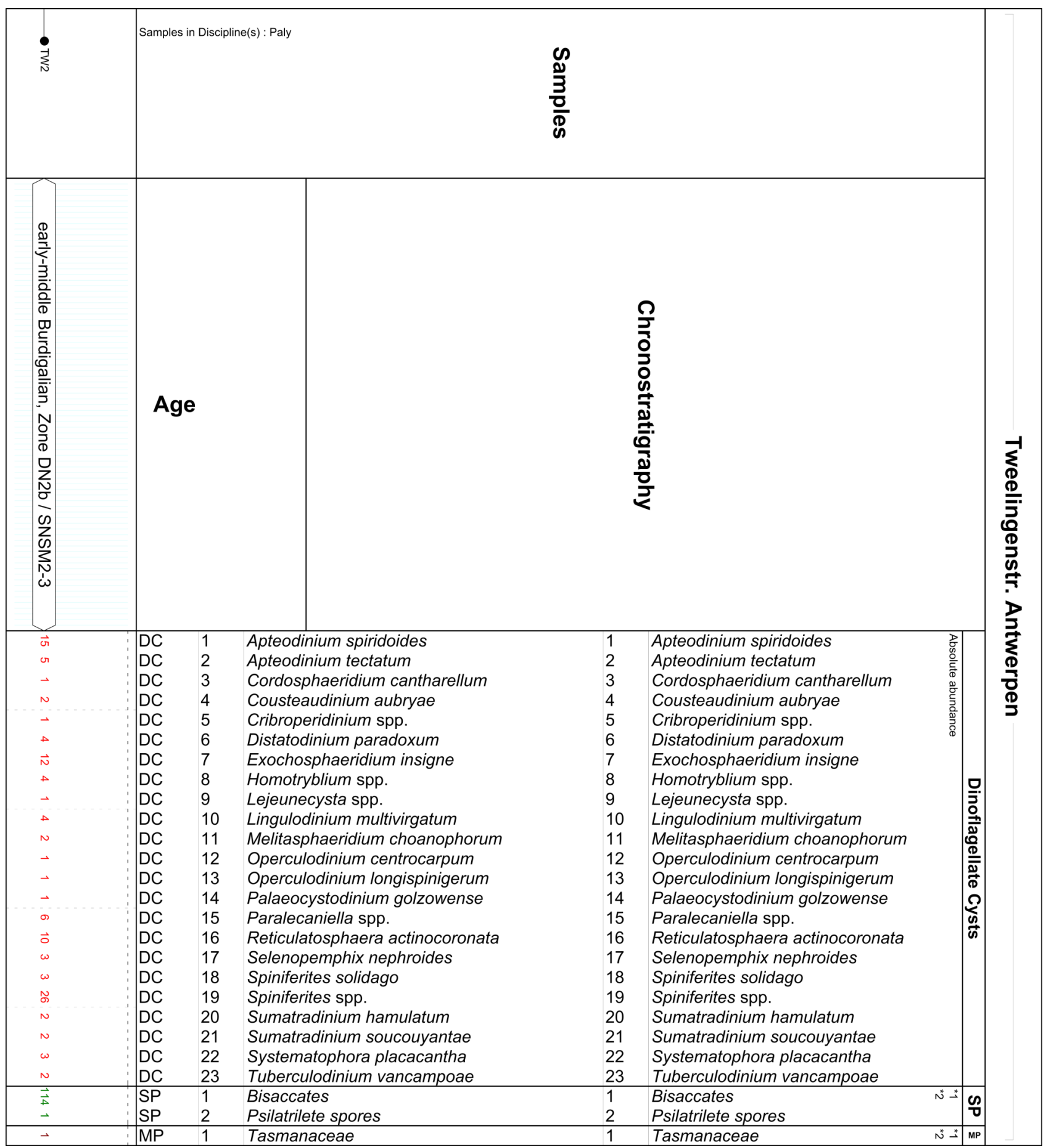

sediment, but here and there the opercular valves (scuta and terga) are preserved in the life position (Plate 1/4-5). Sometimes the terga and/or scuta are preserved at the bottom of the barnacle shells. On 11 Glycymeris specimens, none of the barnacles had terga or scuta preserved. In many Glycymeris specimens, even parts of the periostracum and parts of the external ligament seem to be preserved as a reddish-brown somewhat irregular layer of merged sand grains. The barnacles are attached to the posterior side of the Glycymeris shell; the side exposed to the seawater in life position (Plate 1/1E). This indicates that this part of the Glycymeris shells was exposed over at least several months during life, to allow for this barnacle growth (Crisp \& Bourget, 1985).

On four Glycymeris shells, some of the scuta and the terga are still in place at the top of the barnacle shells (Plate 1/4-5).
Given the fact that the specimens fossilised in their natural position, possibly with the periostracum and the ligament preserved, the population may have been buried alive by a sudden deposit of sand. Afterwards, being never re-exposed to the seawater, they fossilised in life position. Most shells have worm-like holes reminiscent of Maeandropolydora (Plate 1/3). The deep meanders appear mainly on the posterior side of the shells and are often overgrown by barnacles, indicating the shells were infected by Maeandropolydora during lifetime and prior to the barnacle growth.

Even though the articulated Glycymeris occur scattered in this unit, vague concentration in bands is recognizable, which may indicate a varying rate of sedimentation. The abundant presence of barnacles is indicative for shallow water with a low sedimentation rate and a constant water flow and food supply. 
Barnacle assemblages are typical for nearshore, sublittoral $(0$ $100 \mathrm{~m}$ water depth) environments (Doyle et al., 1997), since $73 \%$ of the present barnacle species live in the sublittoral zone and $26 \%$ even inhabits the intertidal zone. Doyle et al. (1997) state that the abundance of barnacles is indicative for the depth of deposition in marine, coarse-grained clastic and rocky foreshores facies, where large concentrations of colonies are linked to the shallowest depths. Combined with the preferred habitat of Glycymeris and spionid worms causing Maeandropolydora traces (see 6.2.), we assume that the water depth was maximum $50 \mathrm{~m}$, probably less than $25 \mathrm{~m}$. This is consistent with the palynological results, as the highest concentration of Paralecaniella spp. is recorded in Argenta unit 2. This indicates that the articulated Glycymeris horizon was deposited in the shallowest palaeoenvironment of the studied succession.

\subsection{Glycymeris-Cyrtodaria horizon}

General character. Coarse-grained, grey glauconitic sand with poorly sorted quartz grains. Few brown-grey phosphatic concretions and some dispersed rounded, blackish pebbles (Plate 7/8) occur. Thanatocoenosis with abundant abraded disarticulated valves of Glycymeris baldii in convex up position (Fig. 4), scattered shark teeth and cetacean remains. This horizon has a thickness between 5 and $20 \mathrm{~cm}$.

Reference sections. Argenta unit 4, depth c. 8.50-8.70 m below surface (De Schutter \& Everaert, 2020, this volume); Tweelingenstraat unit 2, depth c. $9.40-9.45 \mathrm{~m}$ below surface (this study).

Biostratigraphy. Dinocyst biozone DN2b (de Verteuil \& Norris, 1996), zones SNSM2-3 (Munsterman \& Brinkhuis, 2004).

\section{Age. Early-middle Burdigalian.}

Palaeontology. An overview of the recorded macrofossils is given in Table 5. Due to decalcification, the preservation of the calcareous fossils is poor, especially in the Tweelingenstraat section. Gastropods are almost absent, since they are too fragile to survive the sieving process. Nevertheless, the fauna is diverse, considering the decalcification and the small sampling size.

Remarks and discussion. This horizon is characterized by a dominance of Glycymeris baldii (Plate 2/1-3); also Cyrtodaria angusta (Plate 3/11), Cordiopsis polytropa nysti (Plate 3/8) and Glossus burdigalensis cypriniformis (Plate 3/3-4) are common. Compared to other levels in the Berchem Formation, Cyrtodaria is frequently present.

Glossus burdigalensis cypriniformis is characteristic for this horizon; it is the only Glossus species known from the Kiel Sand Member (Louwye et al., 2010). A complete specimen was observed on site. However, even large fragments can be distinguished from the other Glossus-species, by (1) their weak to absent plicae, (2) their rather flat shell and (3) their less distinct umbo, close to the dorsal and posterior margin and almost paralleling the hinge (Herman \& Marquet, 2007, p. 3134 , plate 37). The species also occurs in the contemporaneously deposited Houthalen Sand Member (Bolderberg Formation) in eastern Belgium (Glibert, 1945; Louwye et al., 2010) and is thus considered an index species for the lower Miocene of Belgium (Plate 3/1, 3, 4).

In the past decades, much value has been attached to the presence of Patinopecten brummelii (Plate 3/5) and Cordiopsis polytropa nysti (Plate 3/8) for stratigraphic correlations within the Berchem Formation in Antwerp. According to Marquet (1991), the occurrence of Patinopecten brummelii is restricted to the basal part of the Antwerpen Sand Member, which is dated as latest Burdigalian-early Langhian (biozone DN4) (e.g. Louwye et al., 2010; this study). Due to the abundant presence of Patinopecten brummelii and co-occurrence of Cordiopsis polytropa nysti in the Miocene deposits of Rumst/Terhagen (c. $10 \mathrm{~km}$ south of Antwerp), Marquet (1991) and Herman \& Marquet (2007) correlated the Miocene Rumst section with the basal part of the Antwerpen Sand Member. While the presence of Patinopecten brummelii and Cordiopsis polytropa nysti in the lower-middle Burdigalian Kiel Sand Member challenges the correlation suggested by Marquet (1991) and Herman \& Marquet (2007), their presence does corroborate the dinocyst dating (Burdigalian, biozone DN2c) of the Miocene at Rumst/ Terhagen by Louwye (2005). This shows again that benthic molluscs are less suitable for stratigraphic correlations, even within small areas. Outside the Antwerp area, Patinopecten brummelii is abundant in the Burdigalian Houthalen Sand Member (Bolderberg Formation) in eastern Belgium (Glibert, 1945).

Several fragments of Venus multilamella s.l. Lamarck, 1818, characterized by dense concentric ribs, are present (Plate $3 / 6$ ). This species was not reported from the Deurganckdok Sandstones by Herman \& Marquet (2007). Our findings confirm the continuous presence of this species in the Berchem Formation, as Venus $m$. ringelei Marquet, 2005 and Venus $m$.

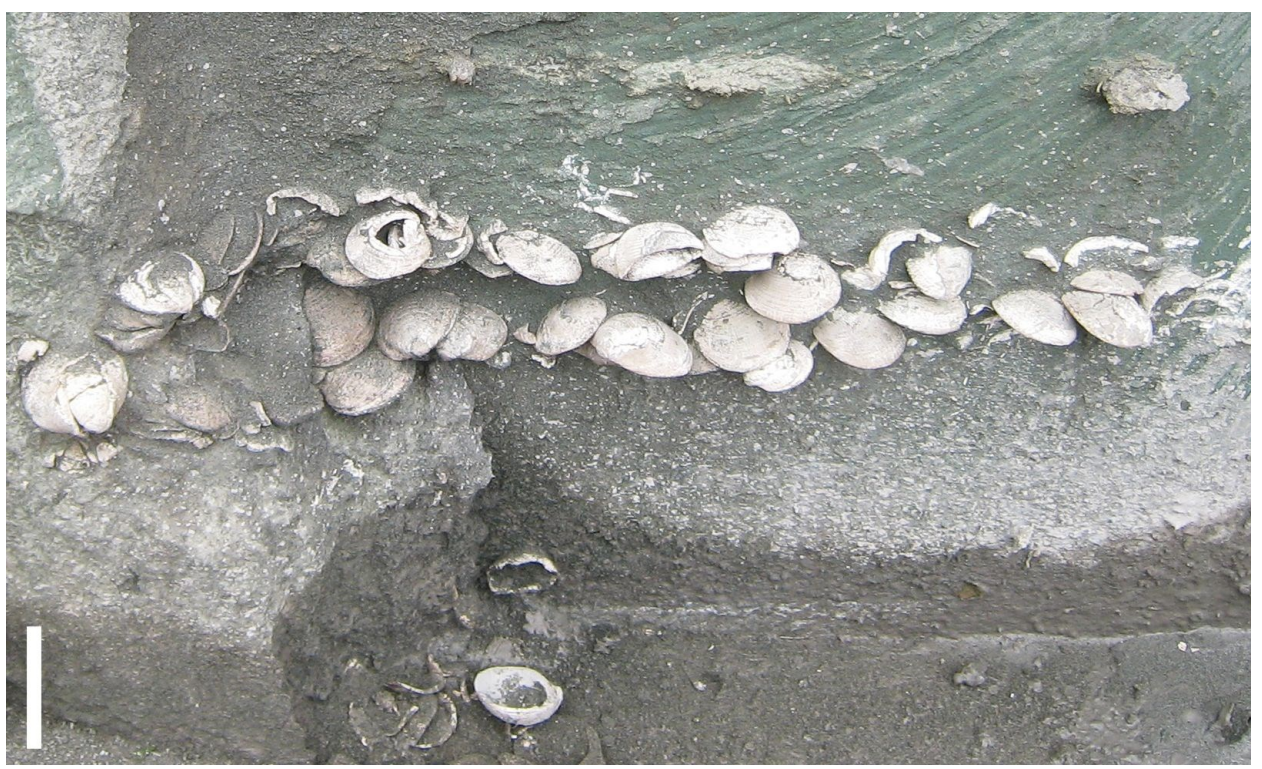

Figure 4. Detail of the Glycymeris-Cyrtodaria horizon (Argenta unit 4) (unnatural colours since the profile is hardened with cementbentonite). Scale bar $10 \mathrm{~cm}$. 
Kiel Sand Member, Glycymeris-Cyrtodaria horizon (AR4, TW2)

\begin{tabular}{|c|c|c|c|}
\hline \multicolumn{4}{|l|}{ BIVALVIA } \\
\hline Glycymerididae & Glycymeris baldii Glibert \& Van de Poel, 1965 & 12 & 2 \\
\hline Yoldiidae & Yoldiella pygmaea (von Münster, 1835) & 2 & 0 \\
\hline Pectinidae & Korobkovia woodi (Nyst, 1861) & 1 & 2 \\
\hline Pectinidae & Pseudamussium lilli (Pusch, 1837) & 2 & 2 \\
\hline Pectinidae & Patinopecten brummelii (Nyst, 1864) & $2+1^{*}$ & 0 \\
\hline Ostreidae & Cubitostrea digitalina (Eichwald, 1830) & $1^{*}$ & 0 \\
\hline Ostreidae & Neopycnodonte indet. & $1^{*}$ & 1 \\
\hline Lucinidae & Cavilucina droueti droueti (Nyst, 1861) & 1 & 0 \\
\hline Astartidae & Astarte cf. goldfussi Hinsch, 1952 & 4 & 0 \\
\hline Astartidae & Astarte radiata Nyst \& Westendorp, 1839 & 11 & 1 \\
\hline Astartidae & Digitaria beyschlageri Kautsky, 1925 & 1 & 0 \\
\hline Cardiidae & Laevicardium subturgidum (d'Orbigny, 1852) & 2 & 0 \\
\hline Ungulinidae & Diplodonta rotundata (Montagu, 1803) & 1 & 0 \\
\hline Glossidae & Glossus burdigalensis cypriniformis (Nyst in Dewalque, 1868) & $1+1^{*}$ & 2 \\
\hline Veneridae & Cordiopsis polytropa nysti (d'Orbigny, 1852) & $2+2^{*}$ & 2 \\
\hline Veneridae & Venus multilamella (Lamarck, 1818) s.l. & $4+1 *$ & 4 \\
\hline Hiatellidae & Cyrtodaria angusta (Nyst \& Westendorp, 1839) & 2 & 7 \\
\hline \multicolumn{4}{|l|}{ GASTROPODA } \\
\hline Naticidae & Natica sp. & 2 & 1 \\
\hline \multicolumn{4}{|l|}{ BRACHIOPODA } \\
\hline Discinidae & Discinisca fallens (Wood, 1872) & 0 & 1 \\
\hline \multicolumn{4}{|c|}{ ELASMOBRANCHII } \\
\hline Hexanchidae & Notorynchus primigenius (Agassiz, 1835) & $1^{*}$ & 0 \\
\hline Cetorhinidae & Keasius rhenanus Reinecke, Von der Hocht \& Dufraing, 2015 - gill rakers & 3 & 7 \\
\hline Lamnidae & Isurus oxyrinchus Rafinesque, 1810 & $1+1^{*}$ & 0 \\
\hline Odontaspididae & Carcharias gustrowensis (Winkler, 1875) & $4^{*}$ & $2+1 *$ \\
\hline Odontaspididae & Araloselachus vorax (Le Hon, 1871) & 3* & $1^{*}$ \\
\hline Carcharhinidae & Carcharhinus priscus (Agassiz, 1843) & $1+3^{*}$ & 3 \\
\hline Carcharhinidae & Galeocerdo aduncus (Agassiz, 1843) & $1 *$ & 0 \\
\hline Carcharhinidae & Physogaleus hemmooriensis Reinecke \& Hoedemakers, 2006 & 2 & 2 \\
\hline Megachasmidae & Megachasma aff. pelagios Taylor, Compagno \& Struhsaker, 1983 & $1^{*}$ & 0 \\
\hline Scyliorhinidae & Pachyscyllium distans (Probst, 1879) & 0 & 2 \\
\hline Squalidae & Squalus alsaticus Andreae, 1892 & 4 & 4 \\
\hline Squatinidae & Squatina sp. & 1 & 4 \\
\hline Rajidae & 'Raja' holsatica Reinecke, Von der Hocht \& Gürs, 2008 & 1 & 7 \\
\hline Rajidae & Atlantoraja cf. cecilae (Steurbaut \& Herman, 1978) ? & 0 & 2 \\
\hline Rajidae & Raja sp. & 0 & 1 \\
\hline Selachii indet. & Indet. fragments & 15 & 8 \\
\hline \multicolumn{4}{|l|}{ CETACEA } \\
\hline Squalodontidae & Squalodon sp. & $1^{*}$ & 0 \\
\hline \multicolumn{4}{|l|}{ TELEOSTEI } \\
\hline Teleostei indet. & Skeletal fragments / Teeth & $46 / 37$ & $60 / 43$ \\
\hline Gadidae & Colliolus sculptus (Koken, 1891) & 7 & 2 \\
\hline Trachinidae & Trachinus sp. & 1 & 0 \\
\hline Sparidae & Dentex sp. & 0 & 1 \\
\hline Sparidae & Sparidae indet. & 0 & 1 \\
\hline \multicolumn{4}{|l|}{ BRYOZOA } \\
\hline Cupuladriidae & Cupuladria cf. haidingeri (Reuss, 1847) & 1 & 1 \\
\hline \multicolumn{4}{|l|}{ ECHINODERMATA } \\
\hline Echinoidea & Spatangidae indet. - plate fragments & 4 & 0 \\
\hline Echinoidea & Stylocidaris? sp. - spines & 0 & 7 \\
\hline \multicolumn{4}{|l|}{ SESSILIA } \\
\hline Balanidae & Balanidae indet. - fragments & 10 & 24 \\
\hline
\end{tabular}

* Picked out during bulk sieving with $5 \mathrm{~mm}$ mesh. Argenta: 300 litres, Tweelingenstraat: 100 litres 
multilamella Lamarck, 1818 are common in the Edegem and Antwerpen Sand Members respectively. Unfortunately, it is impossible to attribute the recorded fragments to one of these subspecies. The presence of the genus Astarte (Plate 3/7) is also new for the Kiel Sand Member, but the genus is well known from both the Edegem and Antwerpen Sand Members (Glibert 1945; Louwye et al., 2010). In the Argenta section, even two articulated specimens of Astarte cf. goldfussi Hinsch, 1952 were found.

Some Ostreoidea are present, of which we attribute the largest specimens to Cubitostrea digitalina (Eichwald, 1830) (Plate 3/10A-B). Similar fragments were observed on site. The species is characterized by its curved outline. The cementing left valve shows coarse radial ribs, and its surface is often irregularly deformed by the substrate. Cubitostrea digitalina is part of the stationary epifauna, typical for shallow, high energy, sublittoral environments, attached on different hard substrata (Mandic \& Harzhauser, 2003). It is known throughout the early -middle Miocene in the North Sea Basin and the Paratethys (e.g. Glibert, 1945; Janssen, 1984; Studencka, 1986; Mandic \& Harzhauser, 2003; Moths et al., 2010; Mikuž \& Gašparič, 2014). Cubitostrea digitalina is rare in the Langhian of the North Sea Basin (Janssen, 1984), Glibert (1945) only reported a single specimen from the Antwerpen Sand Member. However, it appears to be more common in the Burdigalian Houthalen Sand Member (Bolderberg Formation) in eastern Belgium (Glibert, 1945). Also in the late Burdigalian (DN3) of Werder (Germany), the species is a common occurrence (Moths et al., 2010). A second Ostreoidea is represented by small valves of indeterminate juvenile Neopycnodonte (Plate 3/9A-B).

The recorded specimens of Glycymeris baldii in this horizon and the overlying sandstone bed have a slightly different morphology than in the Antwerpen Sand Member. The valves recorded in the Kiel Sand Member seem to be a little more convex and slightly thicker (Plate 2/5-6). The convexity of Glycymeris seems to increase in coarser sediments (Van Nieulande, pers. comm., 2020). The height of the Kiel Sand Member (AR units 4 and 6) valves is equal to, or slightly higher than their length (Plate 2/1-3), while the length of the Antwerpen Sand Member (AR unit 14) specimens generally exceeds their height (Plate 2/4) (Fig. 5A). Also, the symmetry (anterior length/posterior length, after Thomas, 1975) of (large) Glycymeris valves differs in both members, with rather symmetrical valves in the Kiel Sand Member (AR units 4 and 6) and asymmetry (posterior elongation) in the Antwerpen Sand Member (Fig. 5B). Specimens from the articulated Glycymeris horizon (AR unit 2) of the Kiel Sand Member, the oldest part of the studied succession, show a more intermediate morphology (Fig. 5A-B). Also, the material from the Edegem Sand Member figured in Rogalla \& Amler (2007) tends, at first sight, more to the Antwerpen Sand Member morphology. Consequently, these morphological differences should be considered as environmental adaptations, and not as local evolutionary changes. This is consistent with the findings of Thomas (1975): symmetric, orbicular Glycymeris are more adapted to reburial after frequent rolling on coarse gravel bottoms, while asymmetric posterior elongation allows deeper burial in more stable sandy substrates. In other species, Purchon (1939) and Holme (1961) showed that posterior elongation is less common in wave-dominated than in quiet environments, and that posterior elongation is lower in shallower than in deeper waters. The rather symmetric morphology of specimens from both the Glycymeris-Cyrtodaria and the sandstone horizons may indicate a high energetic, shallower habitat.

Vertebrates are also well represented in this horizon. The recorded teleost otoliths are similar to the fauna known from the upper Cordiopsis horizon (Everaert et al., 2019), with species typical for the Miocene of the North Sea Basin (Schwarzhans, 2010). The elasmobranch fauna of this bed resembles the fauna of the Cordiopsis horizon (Everaert et al., 2019). Noteworthy is that the Glycymeris-Cyrtodaria shell bed yielded the second early Miocene in situ record of Megachasma in Europe (De Schutter \& Everaert, 2020, this volume). In addition, some fragments of cetacean vertebrae and a well-preserved tooth of a Squalodon (coll. SE) were found.

The Glycymeris-Cyrtodaria horizon was also recognized in the 1960s in the temporary excavations for the construction of the R1 motorway, as our observations correspond with the brief lithological description of layer 9 in the composite profile of Janssen \& Van der Mark (1968): a horizon of medium fine, black sand with fine gravel, shark teeth, many worn Glycymeris and Cyrtodaria, abundant balanidae and some sandstone plates (see 6.3.). This horizon can probably also be correlated with the lowest shell bed in the Ploegstraat locality at $6.05-6.15 \mathrm{~m}$ below the top of the Miocene as described by Van den Bosch (1966): moderately fine to locally very coarse grained sand with fine
A

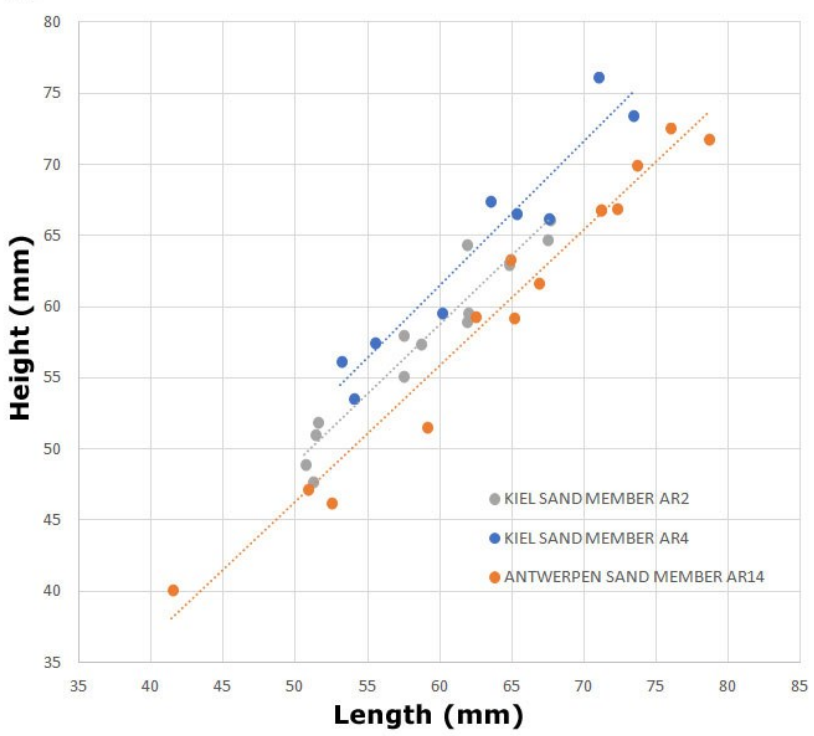

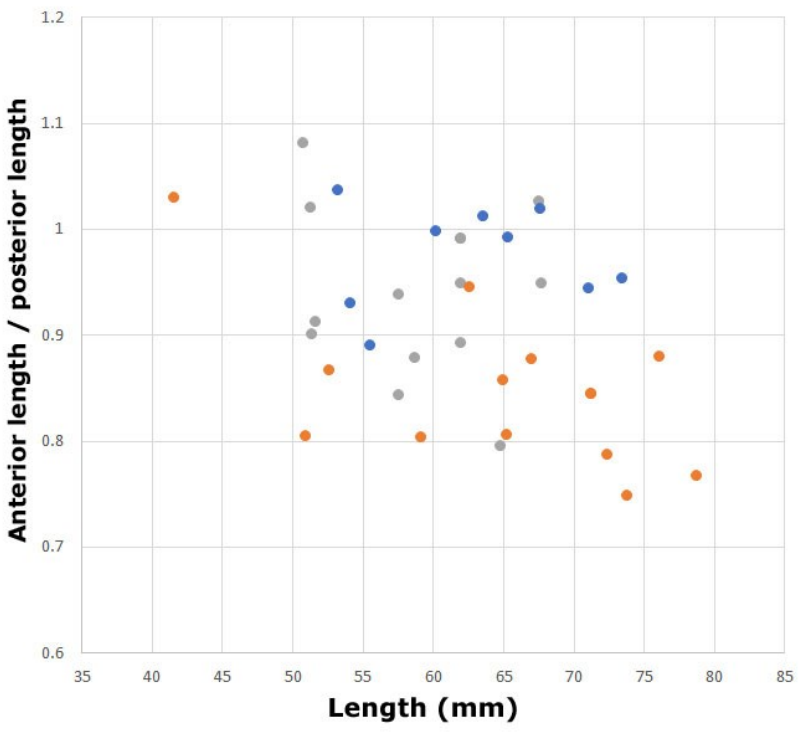

Figure 5. Morphological differences within Glycymeris baldii Glibert \& Van de Poel, 1965 in the Kiel and Antwerpen Sand Members. A. Height and length of the valves B. Asymmetry (and posterior elongation) of the valves. 
gravel, many poorly preserved shells (large Glycymeris). This locality is also known as the Kievitstraat (A.K.) section, however correlation with the profile in De Meuter et al. (1976) is less obvious.

Palaeoenvironment. The taphonomic features indicate that this shell bed was deposited during a single, short, high energy, storm phase, given (1) the limited thickness of the shell bed (up to $20 \mathrm{~cm}$ ), the (2) densely packed molluscs and (3) the stable convex up position of the vast majority of the Glycymeris valves, with only a low percentage of articulated specimens occurring. As the thickness of the overlying sandstone bed is proportional to the thickness of the shell layer at both studied exposures, we hypothesize that the deposition of these two strata occurred during the same storm phase. The (1) convex side up orientation of most Glycymeris, (2) the rather coarse, moderate to poorly sorted sand and (3) the higher concentration of heavier elements (shark teeth, cetacean remains, pebbles, brown-grey phosphatic concretions) are reliable indicators for a storm, tempestite deposit (e.g. Johnson \& Baldwin, 1986; Fürsich \& Oschmann, 1993; Cleveringa, 2000; Mandic et al., 2004; Welton, 2015)

The taphonomy of the recorded fossils indicates relatively low sedimentation rates in their habitat during the pre-storm deposition phase, since the roots of several shark teeth are damaged by bioerosion (Plate 7/2), and are regularly partly covered by authigenic brown-grey phosphatic concretions (Plate $7 / 3$ ). Some shark teeth show traces of transport. Most shells are worn and abraded, which indicates exposure to a high energy environment over a longer period of time (Fürsich \& Oschmann, 1993). Especially the crenate valve margin and the umbonal region of Glycymeris baldii are sensitive to abrasion (Rogalla \& Amler, 2007). Different stages of abrasion are observed in the recorded material, ranging from exposing a reticulate pattern to missing deep layers of the outer shell material in the umbonal region (Plate 2/1-3). In addition to abrasion, the shells were also affected by bioerosion. The dorsal sides of the Glycymeris valves often show long, shallow, sinuous ichnofossil borings with even U-turns, caused by spionid polychaetes. De Schutter \& Everaert (2020) followed Marquet (1984) who figured and discussed similar borings in Glycymerididae, identified as Polydora. However, due to the greater length and the meandering pattern of most borings, we can rather attribute most of the borings to the ichnogenus Maeandropolydora following Bromley \& D'Alessandro (1983), Mikulas \& Pek (1996), Cadée \& Wesselingh (2005) and Árpád (2011). Besides Maeandropolydora sulcans Voigt, 1965 (Plate 2/7) and Maeandropolydora decipiens Voigt, 1965 (Plate 2/9), the ichnospecies Caulostrepsis taeniola Clarke, 1908 is recognized in our material (Plate 2/8). The traces of the latter species are made by, amongst others, the spionid Polydora ciliata (Johnston, 1838) and the eunicid Lysidice ninetta Audouin \& MilneEdwards, 1833 (Árpád, pers. comm., 2020). These polychaetes are nowadays common in shallow marine environments with a soft, muddy bottom and water depths generally less than c. $25 \mathrm{~m}$ (e.g. Boekschoten, 1966; Carrera-Parra et al., 2011).

Other components of the fauna also indicate a shallow depositional environment. The preferred habitat of Glycymeris is the subtidal zone, above the storm weather wave base (e.g. Thomas, 1975; Mandic et al., 2004). The shallow burrowing Glycymeris live on sandy and coarse bottoms that are often subject to fairly strong currents. It is characteristic for physically rigorous environments with biocoenoses of low diversity (Thomas, 1975). The elasmobranch fauna is dominated by coastal, neritic species (e.g. Carcharias, Notorynchus, Carcharhinus). Balanidae and echinoidea are typical for the littoral zone. Also the high numbers of the acritarch
Paralecaniella spp. point to a coastal marine environment.

Summarized, based on the models of Fürsich \& Oschmann (1993), the deposition of the Glycymeris-Cyrtodaria horizon presumably took place in a shallow marine coastal environment (maximum $50 \mathrm{~m}$, probably less than $25 \mathrm{~m}$ deep), during multiple high energy phases. During prolonged exposure on the sea floor, the shells were abraded by wave-induced reworking and encrusted by biota, likely above the fair-weather wave base. Subsequent reworking and transport by storm-induced currents finally produced the tempestite biofabric.

\subsection{Sandstone horizon}

General character. Light grey sandstone lithifications composed of glauconite and quartz grains, cemented by a fine, dense matrix of hardened carbonatic clay/silt. This horizon reaches a thickness between 1 (Tweelingenstraat section) and 15 $\mathrm{cm}$ (Argenta section). The lithifications are laterally continuous with frequent, short, breaks. The thanatocoenosis in the Argenta sandstone bed is similar to the underlying GlycymerisCyrtodaria horizon, dominated by abraded, disarticulated valves of Glycymeris baldii in convex up position (Plate 5/1A). Some articulated valves of Glycymeris, filled with loose coarse glauconitic sand, are observed, enclosed by the lithified matrix (Plate 6/1B). The shelly top side of the lithifications is clearly delineated, the bottom side however is less distinct. Cemented, filled traces of annelids are visible on the bottom side, some decapod burrows (partly) filled with loose sand are observed within the sandstones.

Reference sections. Argenta unit 6, depth c. 8.35-8.45 m below surface (De Schutter \& Everaert, 2020); Tweelingenstraat unit 3 , depth c. $9.37-9.40 \mathrm{~m}$ below surface (this study).

Biostratigraphy. Dinocyst biozone DN2b (de Verteuil \& Norris, 1996), zones SNSM2-3 (Munsterman \& Brinkhuis, 2004).

\section{Age. Early-middle Burdigalian.}

Palaeontology. A limited mollusc fauna is found in the thick lithifications of the Argenta section, together with some teleost and elasmobranch remains. However, in the thin lithifications at the Tweelingenstraat section, the calcareous remains were too fragmented and too decalcified for identification. At first sight, the fossil record of the Argenta sandstone bed is very similar to the underlying shell horizon. However, due to the cemented, dense matrix, more gastropods were recorded than in the underlying beds. The following mollusc species were recognized:

Glycymeris baldii Glibert \& Van de Poel, 1965 - abundant Cyrtodaria angusta (Nyst \& Westendorp, 1848) - common

Glossus burdigalensis cypriniformis (Nyst in Dewalque, 1868) - occasional

Laevicardium subturgidum (d'Orbigny, 1852) - common

Diplodonta cf. rotundata (Montagu, 1803) - occasional

Astarte radiata Nyst \& Westendorp, 1839 - occasional

Lucinoma borealis (Linnaeus, 1767) - occasional

Spisula aff. subtruncata (Da Costa, 1778) - occasional

Haustator eryna (d'Orbigny, 1852) - common

Echinophoria cf. bicoronata (Beyrich, 1854) - occasional

Ficus sp. - occasional

Natica sp. - occasional

Turridae indet. - occasional

Remarks and discussion. The hard, thick cemented sandstone bed is a distinct level in the more than $12 \mathrm{~m}$ thick sequence of glauconitic sand at the Argenta exposure. The 
lithology and taphonomy are very similar to the Deurganckdok Sandstone Bed of Herman \& Marquet (2007). Both in our material and the Deurganckdok sandstones, many tubes of sedentary annelids, presumably polychaetes, are observed, especially in the basal side of the lithifications (Plate 6/1D; Herman \& Marquet, 2007, plate 19). The fauna and taphonomy of the shells in the sandstone bed are identical to the underlying Glycymeris-Cyrtodaria horizon. The concentrations of Glycymeris found in the upper part of the lithifications from the Argenta site are similar to those figured in Herman \& Marquet (2007, pl. 24, 34).

However, some differences exist with the Deurganckdok fauna as described by Herman \& Marquet (2007). As already mentioned by De Schutter \& Everaert (2020), Haustator eryna is frequently observed in the lithifications of the Argenta section. Lithification IRSNB 7679, in situ collected, shows two clearly identifiable fragments (one in Plate 4/1D). Also, in the displaced blocks of the Argenta section (IRSNB 7680-7681, collected by S. Knoll), several Haustator eryna were recorded (Plate 5/1BC). However, Herman \& Marquet (2007) did not mention this species from the Deurganckdok Sandstone Bed. The species is also recorded from the Houthalen Sand Member (Bolderberg Formation) in eastern Belgium (Glibert, 1952), which was probably contemporaneously deposited with the Kiel Sand Member (Deckers \& Louwye, 2019). According to Janssen (1984), Haustator eryna is an index species for the Hemmoorian (middle Burdigalian to early Langhian) of the North Sea Basin. In the Antwerp area, Haustator eryna is supposed to be restricted to a single unit in the basal part of the Antwerpen Sand Member (biozone DN4, latest Burdigalian-Langhian) according to Marquet (1991) and Louwye et al. (2010), and considered to be a local mollusc biostratigraphic marker species. Our specimens from the sandstone horizon (DN2 zone) are at least 2 Ma older than those in the basal Antwerpen Sand Member (DN4 zone). Hence, Haustator eryna has a longer stratigraphic range in the Antwerp area than has been assumed in recent decades. Interestingly, Van den Bosch et al. (1975, p. $83,107)$ already mentioned the presence of Haustator eryna in some calcareous concretions from the Kiel Sand Member (coll. NBC) at the temporary Berchem - Grote Steenweg (A.G.) exposure (BGD 028W0397, DOV kb15d28w-B451) (Fig. 1), but this observation was overlooked in later studies. Louwye et al. (2010) suggest that Haustator eryna may be typical for deeper environments and Turritella subangulata (Brocchi, 1814), occurring in the higher parts of the Antwerpen Sand Member and in the Edegem Sand Member, for shallower environments. However, our observations conflict with this hypothesis, as both the Kiel Sand Member, deposited in a shallow marine environment, and the coastal Miocene deposits of Rumst (unpublished data SE) only contain Haustator eryna. In other sections of the southern North Sea Basin, e.g. in the Langhian Miste Bed of the eastern Netherlands (Janssen, 1984), both species co-occur. Thus, it seems plausible that the occurrence of Haustator eryna is not affected by these specific environmental conditions (Van den Bosch et al., 1975).

Teleost and elasmobranch fossils were not reported from the Deurganckdok Sandstone Bed. However, an anterior tooth of Isurus oxyrinchus was found in situ in the thin sandstone horizon at the Tweelingenstraat construction pit (Plate 4/2) and several shark and teleost teeth were found in lithifications from the Argenta exposure (Knoll, pers. comm., 2019).

Palaeoenvironment. The sandstone horizon in the study area and the Deurganckdok Sandstone Bed are both placed in biozone DN2 (Louwye \& Mertens, 2007; this study). The Deurganckdok Sandstone Bed was regarded by Herman \& Marquet (2007) as a tempestite. Despite the similar matrix, taphonomy and lithology, it cannot be concluded that the
Argenta and Tweelingenstraat sandstone beds originate from the same event as the Deurganckdok lithifications. The resolution of the biozone is too limited and the geographical distance between the Deurganckdok and the study area is too far. An important difference is the presence of remains of a suspected mangrove environment (root traces and wood fragments of Bruguiera sp.) in the Deurganckdok Sandstone Bed (Herman \& Marquet, 2007), which are lacking in the studied sections.

Herman \& Marquet (2007, p. 92) discussed the presence of annelids on the bottom side of several Deurganckdok sandstone slabs. Many sedentary polychaetes live in non-calcareous tubes, often consisting of grains held together by mucus (e.g. terebellids), and are commonly found on the lower side of overhanging hard surfaces (Wilson \& Palmer, 1992), which offers them shelter against currents and waves. Herman \& Marquet (2007) therefore suspected that these annelids did not appear until the lithifications were hardened to some degree. This would imply undercutting of the lithified sediment and forming of cavities, for which there are no indications at the Argenta and Tweelingenstraat sections. We hypothesize that the annelids burrowed the soft sea bottom prior to the onset of lithification, and selective cementation of the annelid tubes due to permeability differences preserved them at the transition from cemented to uncemented sediment.

As the thickness of the sandstone bed is proportional to the thickness of the underlying shell bed at both the Argenta and the Tweelingenstraat sections, we suggested above that the sandstone bed and its fossil content may be the result of a single storm phase. The high energy conditions induced by a storm bring a lot of fine sediment in suspension near the sea floor. When the storm wanes and the strength of the wave oscillation decreases, the suspended, fine sediment can finally settle on the sea floor (Nichols, 2009). The abraded, by spionid worms bored (Plate 4/1A) and less commonly barnacles encrusted (Plate $4 / 1 \mathrm{~F})$ Glycymeris trapped in the matrix, likely have the same origin as those from the underlying shell bed. A few articulated Glycymeris in the sandstones (orientated in bedding plane) show that these shells have been relocated, as they are filled with coarse-grained, non-cemented glauconitic sand (Plate 6/1B). A few mucus cemented worm tubes were observed in the articulated Glycymeris valves, between the loose sand. The carbonate-rich, clayey glauconitic sand mass must first have been plastic, and only then gradually cemented. For example, hollow non-cemented decapod burrows are observed, upwards orientated starting from the bottom (Plate 4/1C and Plate 6/1B bottom right). Possibly, these may be escape routes after having been buried. The upper side of the lithifications is dominated by disarticulated, convex up orientated Glycymeris valves (Plate 5/1A) and Haustator eryna without clear direction.

\subsection{Cordiopsis horizon}

General character. A 1-15 cm thick horizon, consisting of grey, medium-fine to coarse-grained glauconitic sand with local concentrations of mainly strongly decalcified, very fragile Cordiopsis polytropa nysti. Most of these bivalves are disarticulated, convex up orientated valves (Fig. 6B). However, some articulated valves are present (Fig. 6A). Many browngrey, rounded phosphatic concretions are present (Plate 7/6), skeletal elements of teleosts are abundant and numerous wellpreserved elasmobranch teeth occur. At the base of this horizon, several cetacean remains and transported sandstone chunks are encountered. The thickness of this horizon is very variable and it may have a slightly wavy appearance, with coarser and heavier material concentrated in lenses.

Reference sections. Argenta unit 8, depth c. 6.50-6.65 m below surface (De Schutter \& Everaert, 2020); Post X unit 2, 

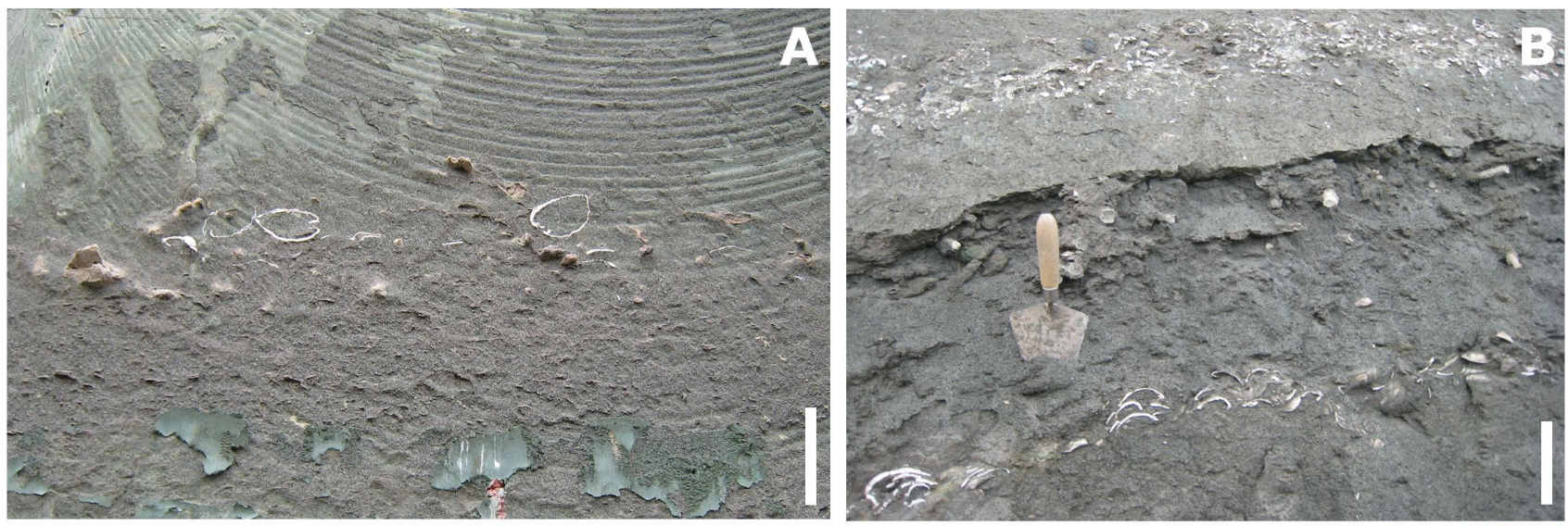

Figure 6. Detail of the Cordiopsis horizon. A. Argenta section: abundant brown-grey phosphatic concretions and sandstone fragments (unnatural colours due to cement-bentonite). B. Post X section: convex up oriented Cordiopsis valves. The base of the overlying Antwerpen Sand Member overhangs the Kiel Sand Member, as the latter is less erosion resistant. Several lithified burrows are present just below the base of the Antwerpen Sand Member. Scale bar $10 \mathrm{~cm}$.

depth c. $7.00-7.15 \mathrm{~m}$ below surface (Everaert et al., 2019); Tweelingenstraat unit 5 , depth c. 7.00-7.05 m below surface (this study).

Biostratigraphy. Dinocyst biozone DN2b (de Verteuil \& Norris, 1996), zones SNSM2-3 (Munsterman \& Brinkhuis, 2004).

\section{Age. Early-middle Burdigalian.}

Palaeontology. An extensive overview of the fossils in this level at the Post X section is given by Everaert et al. (2019), containing a rich fauna of at least 30 elasmobranch species, several cetacean (Eurhinodelphinidae, Kentriodontidae, Physeteroidea), teleost (11 genera), cheloniid and even bird (Procellariiformes) remains. Due to heavy decalcification, the mollusc fauna is poor: apart from dominant Cordiopsis polytropa nysti, some Glycymeris baldii were observed, next to some smaller calcitic molluscan remains. In addition, echinoid spines, barnacles and benthic foraminifera were figured. Also, some plant remains occurred including Taxodioxylon driftwood and Magnolia seeds. The recorded fauna at the Argenta section is very similar.

Remarks and discussion. The elasmobranch fauna of this horizon is rich and diverse (Everaert et al., 2019). Dinocyst analysis shows that it is slightly older than the German WerderUesen fauna (Reinecke et al., 2011), which is placed in dinocyst biozone DN3 of de Verteuil \& Norris (1996). However, the elasmobranch fauna in the Cordiopsis horizon is less diverse than the Werder-Uesen fauna.

Just like the Werder-Uesen fauna, teeth of Isurus oxyrinchus are very common in the Cordiopsis horizon and outnumber Carcharodon hastalis (Agassiz, 1843) by 5.6/1 (Everaert et al., 2019). Apparently, this dominance of Isurus oxyrinchus is typical for the Burdigalian in the southern North Sea Basin. By the end of the Burdigalian, Isurus oxyrinchus retreated from the North Sea Basin to become an occasional visitor in the early Langhian (Bor et al., 2012).

At the Argenta section, the marine mammal fauna is similar to that of Post X (Everaert et al., 2019), with mainly teeth and/or vertebrae remains of both Eurhinodelphinidae and Kentriodontidae (a.o. Delphinodon cf. dividum True, 1912) well represented. More rarely, Physeteroidea occur (Orycterocetus cf. crocodilinus Cope, 1868). A Physeterula neurocranium was found at the Post X section (unpublished data MB, coll. RBINS).
Palaeoenvironment. The sand is finer than in the lower horizons (Fig. 9). This general fining upward trend in the Kiel Sand Member can be explained by the ongoing transgression, which implies that the Cordiopsis horizon was deposited in a slightly deeper environment compared to the lower shell beds. This is confirmed by the palynological analyses. High numbers of Paralecaniella spp. indicate restricted-marine conditions. The relative numbers of Paralecaniella spp. on the total sum of marine palynomorphs comprise only $2.5 \%$ at the Cordiopsis horizon, but increase to $18 \%$ at the Glycymeris-Cyrtodaria horizon and $25 \%$ at the articulated Glycymeris horizon. Meanwhile, Spiniferites spp. (55.6\% at the Cordiopsis horizon) shows an opposite trend, viz. an increase of approximately $20 \%$ of the total sum dinocysts, compared to both mentioned deeper horizons. Dominant numbers of Spiniferites spp. point to openmarine neritic conditions (Brinkhuis, 1994; Powell et al., 1996). Inner-neritic and restricted-marine species are subsidiary.

The elasmobranch fauna of the Cordiopsis horizon (Everaert et al., 2019, table 1) is strongly dominated by benthic species (Rajidae, Dasyatidae, Squatina sp.). Benthopelagic taxa (Squalus, Notorynchus, Carcharias, Carcharhinus, Physogaleus, Galeocerdo) occur in fewer numbers. Pelagic taxa are almost absent, only gill rakers of Keasius and teeth of Isurus are found regularly. All recorded species indicate a shallow, coastal shelf environment in a warm-temperate to subtropical climate. Everaert et al. (2019) estimated the water depth between 20 and $40 \mathrm{~m}$, based on the abundance of elasmobranch taxa compared to the habitat, habit and depth range of the extant species (see Bor et al., 2012, p. 104-105).

Everaert et al. (2019) suggested mechanical sorting through winnowing as the main process driving the formation of the fossil concentration in this horizon. In the sand below the Cordiopsis horizon (PX unit 1), some scattered shark teeth were found by sieving of large quantities of sediment (Hoedemakers, pers. comm., 2020). By winnowing, the fine-grained sediment is selectively removed and heavier (bio)clasts become concentrated (Fürsich \& Oschmann, 1993). This process may be caused by storms, since most of the observed valves were convex up orientated and densely packed in the small shell concentrations (Fig. 6B). Due to the strong decalcification, little can be said about the taphonomy of the shells. However, the vertebrate remains are extremely well preserved and are not affected by abrasion. The shark teeth show almost no bioerosion, which implies that they were covered with sediment relatively rapidly, in the pre-winnowing phase. Only a small number of teeth is partly covered with typical brown-grey 


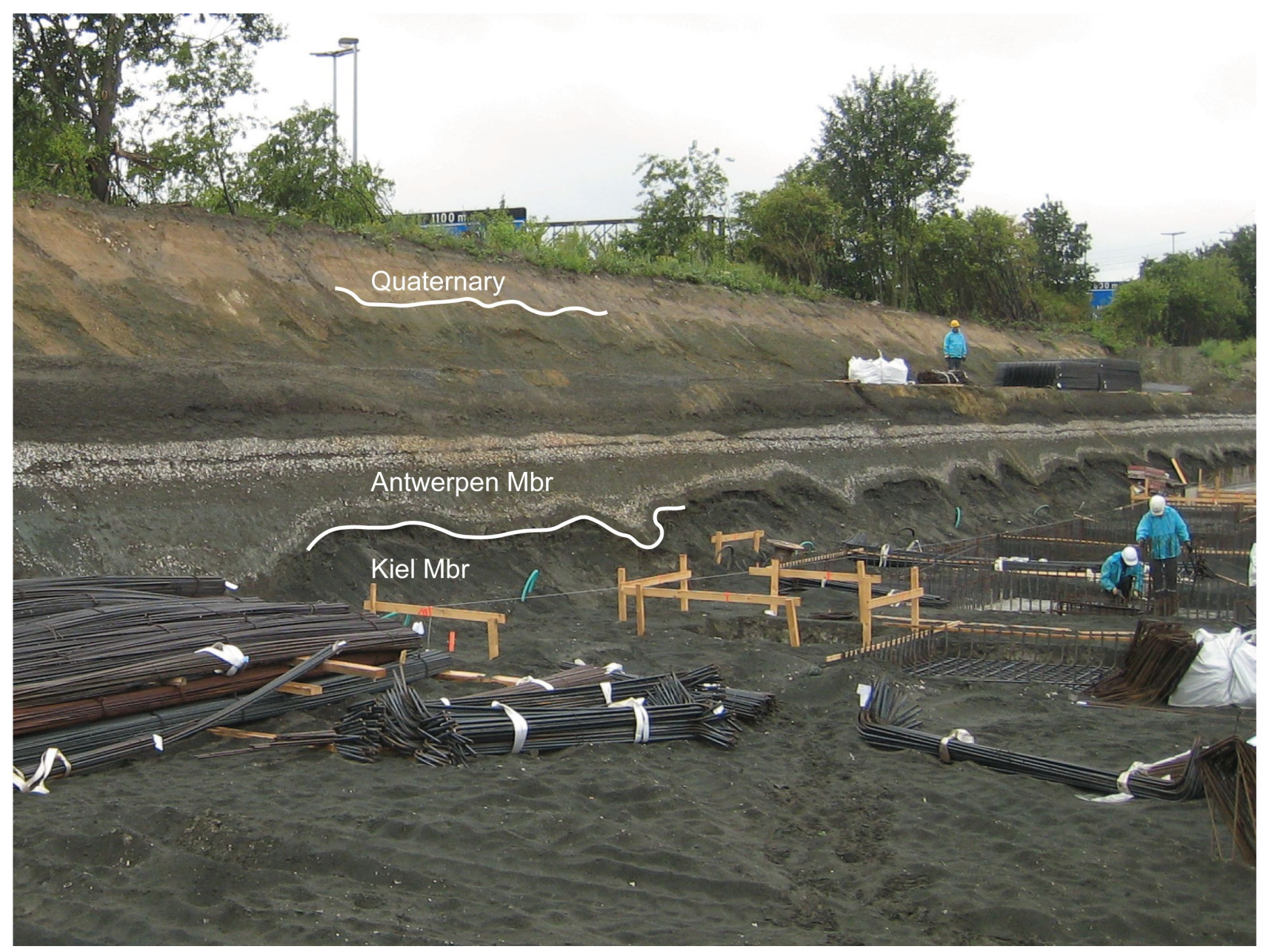

Figure 7. Load casting base of the Antwerpen Sand Member (Post X section).

phosphatic concretions (Everaert et al., 2019, plate 2/2). The proportion of teeth with attached phosphate concretions is smaller than in the Glycymeris-Cyrtodaria horizon. It is indicative that the heavier parts, such as sandstone chunks, mainly rest on the base of this horizon. These characteristics largely correspond to the winnowed concentration model of Fürsich \& Oschmann (1993). In general, winnowed concentrations can be a result of storm waves, storm flows or weak currents.

This level is the youngest horizon of the DN2 biozone at both the Post $\mathrm{X}$ and Argenta sections, covered by c. $0.5 \mathrm{~m}$ of decalcified, grey, glauconitic sand, attributed to biozone DN3 (sample PX3). The boundary between biozones DN2 and DN3 was also recognised by Louwye et al. (2000) in sample 8 of the Berchem - Grote Steenweg (A.G.) section (Fig. 1) (samples of De Meuter et al., 1976), a horizon described as "locally very friable shell fragments preserved in clay streaks and sandstones". Several metres of bioturbated, decalcified glauconitic sand are under (biozone DN2) and overlying (biozone DN3) this level at the A.G. section. The concentration of shark teeth, bones, shells and abundant, more or less rounded, brown-grey phosphatic concretions on the contact between the biozones DN2 and DN3 indicates the presence of a hiatus, which is not extensive, given the excellent preservation condition of the shark teeth and cetacean remains, and the fact that there is no biozone missing.

\section{Macrofossils and palaeoenvironment: basal layers Antwerpen Sand Member}

In the study area, the Kiel Sand Member is truncated at different stratigraphic levels (Louwye et al., 2000; Fig. 11), hence it is important to characterize the basal part of the overlying Antwerpen Sand Member.

General character. The basal part of the Antwerpen Sand Member consists of dark to black coloured, clayey, very glauconitic, rather fine sand. The lowest part is formed by 5-20 $\mathrm{cm}$ of sediment with very few mollusc shells (e.g. PX unit 4). Some flat, small, reworked sandstones may rest at the base (e.g. Hoedemakers \& Dufraing, 2018, fig. 17), their abundance may vary between locations. On top of this sandy layer, a massive 25 $\mathrm{cm}$ thick shell bed is observed in southern sections in Berchem (e.g. Posthofbrug unit 2, see Louwye et al., 2010; PX unit 5), consisting of Glycymeris baldii, Patinopecten brummelii, Cordiopsis polytropa nysti, Glossus lunulatus lunulatus and Haustator eryna.

Large Neopycnodonte navicularis are present in the lower part of this shell bed, while in the upper part, black (partially authigenic) phosphatic concretions occur together with shark teeth and cetacean bones. Locally, this shell level can strongly undulate due to load casting (Fig. 7), and may split in two separate, parallel layers. In the more northern Argenta and Tweelingenstraat sections, this shell layer splits into two distinct shell beds (each up to $20 \mathrm{~cm}$ in thickness): a lower, sometimes undulating layer (hereafter informally named as "basal shell bed": AR unit 10, TW unit 6) and an upper, horizontal layer with black phosphatic nodules (hereafter informally named as "Haustator eryna phosphatic horizon": AR unit 12, TW unit 8).

The basal shell bed of the Antwerpen Sand Member was thicker in the Tweelingenstraat than in the Argenta section. The shell horizons are separated by $30-60 \mathrm{~cm}$ of dark, clayey glauconitic sand. At the Tweelingenstraat, fossils are almost 
absent in this interval (TW unit 7). Scattered, large articulated Glycymeris were observed in this intermediate level at the Argenta site (AR unit 11).

Reference sections. Argenta units 10, 11 and 12, depth c. 5.20-6.00 m below surface (De Schutter \& Everaert, 2020); Post $\mathrm{X}$ units 4 and 5, depth c. 5.90-6.30 m below surface (Everaert et al., 2019); Tweelingenstraat units 6, 7 and 8, depth c. 6.10-7.00 $\mathrm{m}$ below surface (this study).

Biostratigraphy. Biozone DN4 (de Verteuil \& Norris, 1996), zones SNSM5-6 (Munsterman \& Brinkhuis, 2004).

Age. Latest Burdigalian - early Langhian.

Palaeontology. The basal part of the Antwerpen Sand Member contains a diverse fauna (see Louwye et al., 2010, table 2 from the Posthofbrug section, DOV TO-20100101). The basal shell bed and the Haustator eryna phosphatic horizon could be individually sampled at the Argenta and the Tweelingenstraat sections, showing a more diversified mollusc fauna in the Haustator eryna phosphatic horizon (unpublished data SE). Haustator eryna occurs in both shell beds.

Remarks and discussion. A sharp lithological boundary between the Kiel Sand Member and the overlying Antwerpen Sand Member could be observed in all studied sections. Clear load casting structures can arise at the base of the Antwerpen Sand Member: the basal shell bed can show a continuous undulating course with wide U- to even V-shaped collapses into the top of the Kiel Sand Member. The orientation of the mollusc valves follows the undulations, which indicates that the shell bed only collapsed after horizontal deposition. The situation stabilized quickly and the horizontal stratification was restored. Especially at the Post $\mathrm{X}$ section, this load casting phenomenon is fairly extreme (Fig. 7; Everaert et al., 2019, figs 6-7), probably because at that section, the base of the Antwerpen Sand Member was formed by a thick, compact, heavy shell bed and a band of dense clayey sand (PX units 4 and 5). Similar deformations were also observed at a temporary exposure in the Filip Williotstraat (Berchem Stadion, unpublished data, PDS 2009) (see Fig. 1, FW). Also, at the Argenta and the Tweelingenstraat sections, clear undulations were observed, but less extreme than those at the Post X section. At the Post X section, we observed that in case of extreme collapses, the Cordiopsis horizon near the top of the Kiel Sand Member occasionally slightly bends downwards, which indicates some form of fluidity of the sediment at the time. To a lesser extent, this was also visible at the Argenta section.

To the north, the lower shell bed (PX unit 5) splits into several different, distinct shell horizons. More northeast in the Borgerhout - Stenen Brug (I S.B.) section (Fig. 1) (BGD 028E0497, DOV kb15d28e-B578), De Meuter et al. (1976) even mention a single layer of Haustator eryna between the shell beds. In contrast, Neopycnodonte navicularis is only relatively abundant at the base of the Antwerpen Sand Member, as observed earlier by De Ceuster (1987) at the Antwerpse Hypotheekkas (An. Hyp.) section (Fig. 1). To the south, the Antwerpen Sand Member wedges out and the lower part becomes even completely decalcified (PHB-3 section (Fig. 1), DOV TO-20150105B, Hoedemakers \& Dufraing, 2018). When the shell layers are closely spaced or unseparated, authigenic black phosphorites are only observed in the upper part. This was also noted by Hoedemakers \& Dufraing (2018) in the PHB-2 section (Fig. 1) (DOV TO-20150105A).

The lower boundary of the Antwerpen Sand Member is sharp because it is clearly finer-grained and it contains more

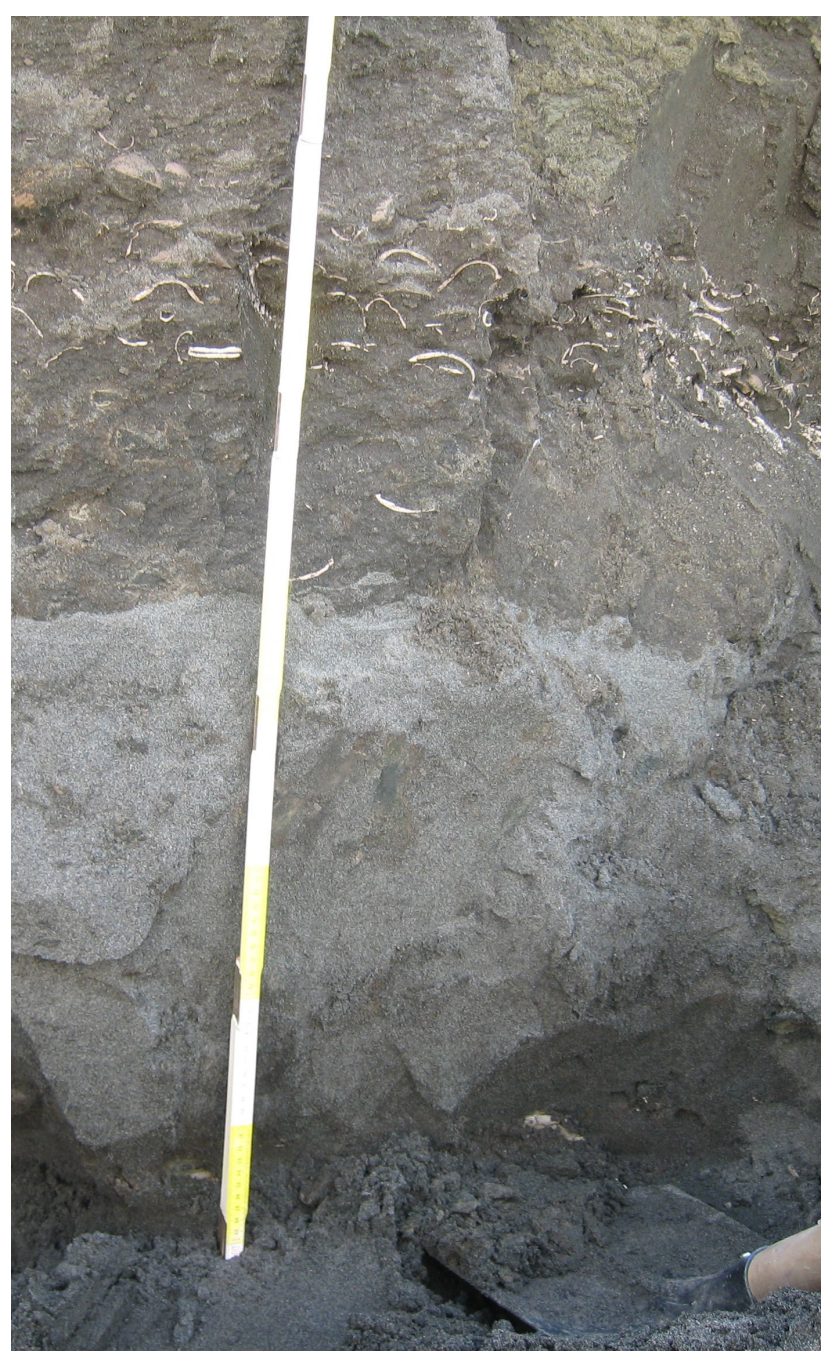

Figure 8. Lithological boundary between the Kiel Sand Member and the overlying Antwerpen Sand Member (Post X section). At the bottom, the Cordiopsis horizon can be observed.

clay compared to the underlying Kiel Sand Member (Figs 8-9). The abrupt lithological break and the local presence of small transported sandstone fragments indicate an erosional surface. The erosive contact with the underlying Kiel Sand Member affects the fossil and lithological content of the base of the Antwerpen Sand Member. In contrast to the Kiel Sand Member, Isurus oxyrinchus is much less represented in the autochthonous fauna of the Antwerpen Sand Member, where the Lamnidae are strongly dominated by Carcharodon hastalis, similarly as observed in the Langhian Miste Bed of the eastern Netherlands (Bor et al., 2012). We noticed that when the Cordiopsis horizon is absent (Tweelingenstraat section), relatively more teeth of Isurus oxyrinchus occur at the base of the Antwerpen Sand Member, together with many brown-grey phosphatic concretions. As these concretions only occur abundantly in the Cordiopsis horizon, we assume that the base of the Antwerpen Sand Member has reworked the Cordiopsis horizon. In contrast, when the Cordiopsis horizon is present (e.g. Argenta section), shark teeth, Isurus oxyrhinchus in particular, and brown-grey phosphatic concretions are almost lacking in the basal shell bed of the Antwerpen Sand Member (AR unit 10).

Palaeoenvironment. The basal part of the Antwerpen Sand Member was characterized by Louwye et al. (2010) as an open marine, neritic environment in a warm-temperate to subtropical 

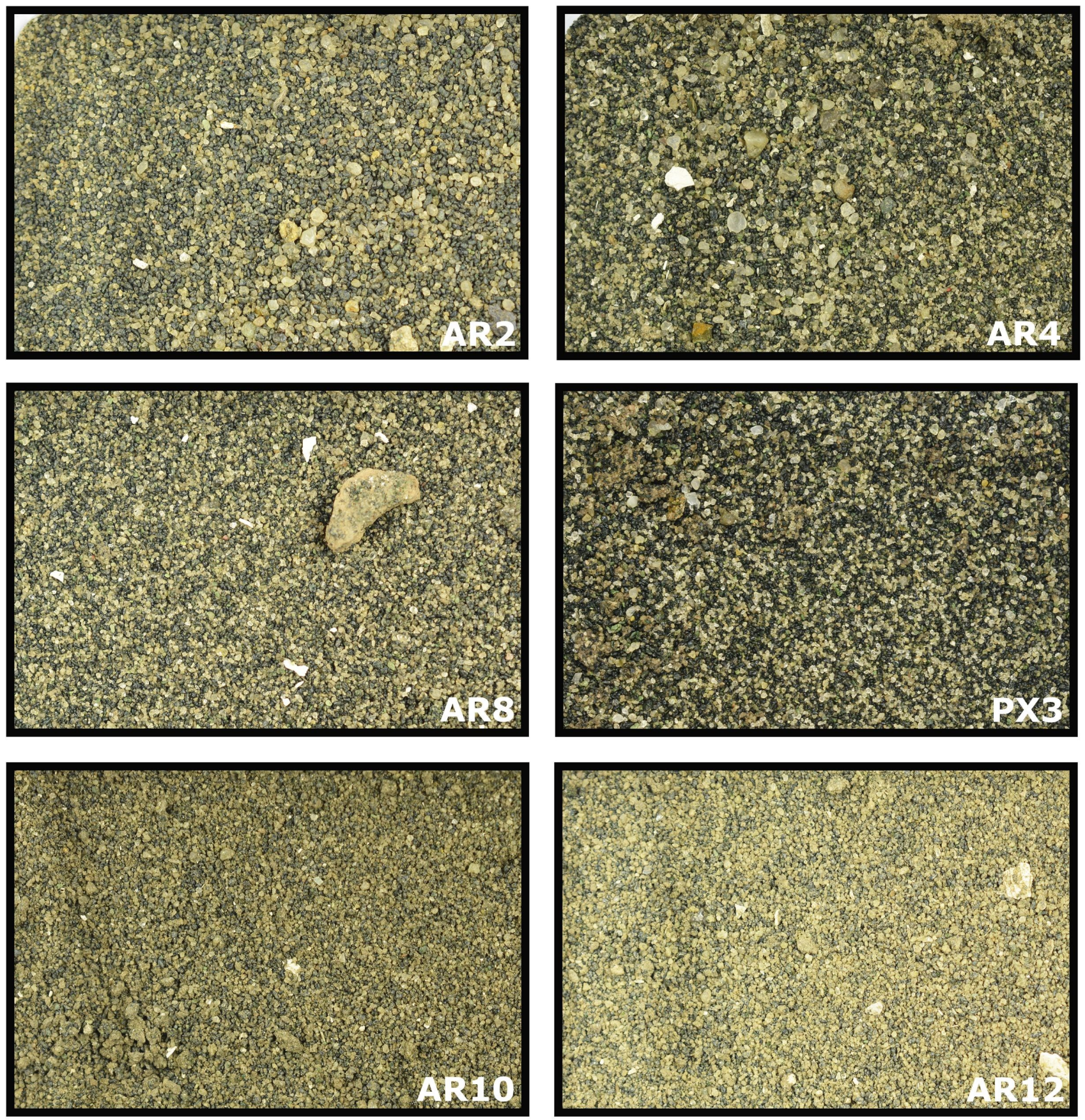

Figure 9. Sediment samples of the discussed horizons. Kiel Sand Member: AR2 (articulated Glycymeris horizon), AR4 (GlycymerisCyrtodaria horizon), AR8 (Cordiopsis horizon), PX3 (Post X unit 3). Antwerpen Sand Member: AR10 (basal shell bed), AR12 (Haustator eryna phosphatic horizon). Scale: $3 \times 2 \mathrm{~cm}$. Additional samples are kept in the BGD collection.

climate. Our observations, based on both macrofossils and palynology, are analogous to Posthofbrug unit 2 in Louwye et al. (2010). The basal part of the Antwerpen Sand Member is deposited in deeper, less energetic waters than the underlying Kiel Sand Member. In this calmer environment, clay particles could settle.

The orientation of the Glycymeris valves is, especially in the Haustator eryna phosphatic horizon, more ambiguous than in the previously discussed horizons of the Kiel Sand Member. Although most of the valves are convex up orientated, articulated specimens often occur. A small number is concave upwards orientated.

The upper shell bed (Haustator eryna phosphatic horizon) is characterized by the presence of dark green to black phosphatic concretions (Plate 7/7). Both irregular, rough, more fragile concretions and rounded, hard nodules occur. Rounded nodules may be reworked from older strata. Phosphatic concretions are also present as inner casts of molluscs, with their calcareous shell sometimes still present. The latter observation is a clear indication that the phosphorite was, at least partially, formed in situ, and can be regarded as authigenic. Shark teeth are sometimes preserved in a phosphatic matrix. The in situ formation and accumulation of phosphate nodules or concretions can be indicative for nutrient-rich, warm waters and slow sedimentation rates, when the supply of sediment to the shelf is reduced by e.g. high sea levels (Nichols, 2009). The phosphate may also originate from decomposing skeletons and bones in an environment of low sedimentation. The taphonomy of the shark teeth supports a reduced sedimentation rate: the roots of most teeth of Carcharodon hastalis are affected by 

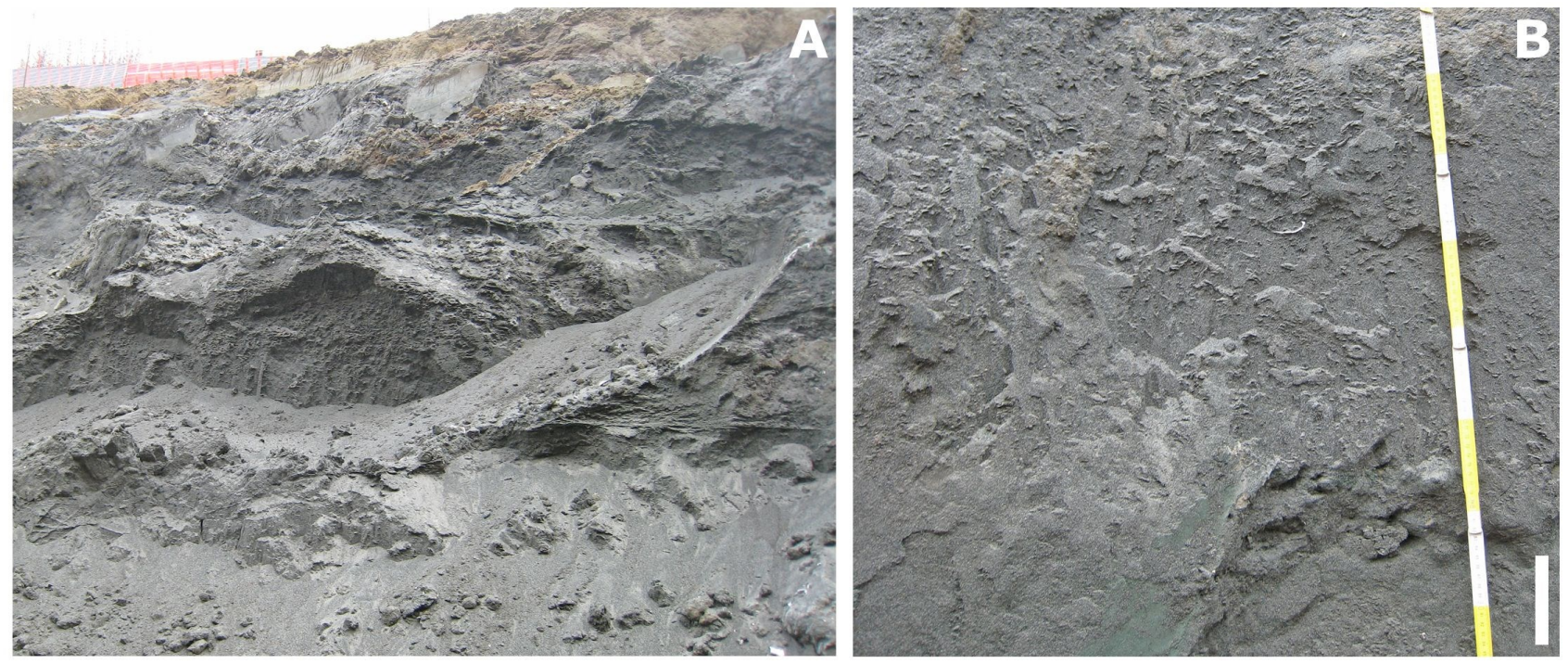

Figure 10. Bioturbated sediment of the Kiel Sand Member, eroded by wind and rain. A. Argenta unit 7, B. Argenta unit 9 . Scale bar $10 \mathrm{~cm}$.

bioerosion by microorganisms, some roots have even completely disappeared. The microorganic colonization of the roots develops during the early diagenesis on the sea water/ sediment boundary, and just after burial (Cappetta, 2012).

\section{General discussion and conclusions}

Due to a spatial limited decalcification front, the Kiel Sand Member is completely decalcified in southern Antwerp. However, the Kiel Sand Member gradually becomes fossiliferous to the north and east of the city. Based on lithology, and independent of the presence or absence of calcareous fossils, the Kiel Sand Member could easily be distinguished from the overlying Antwerpen Sand Member in all studied sections, especially when the sediment is dry (Fig. 8). This difference is mainly caused by the low clay content, a slightly lower glauconite/quartz ratio and the coarser grain size in the Kiel Sand Member, compared to the clayey, fine-grained, very glauconitic sand in the base of the Antwerpen Sand Member (Fig. 9). Chronostratigraphically, the Argenta section is the most complete sequence of the fossiliferous Kiel Sand Member, exposing a few shell horizons situated in between several metres of bioturbated, relatively coarse-grained, grey sand, apparently lacking macrofossils (Fig. 10). These burrows occur in all Kiel Sand Member sections (De Meuter et al., 1976; Gaemers \& De Ceuster, 1978; De Ceuster, 1987; Hoedemakers \& Dufraing, 2018; Everaert et al., 2019; De Schutter \& Everaert, 2020; present study). Based on these characteristics, we reinterpret the lower part of the Kievitstraat section (A.K.) in De Meuter et al. (1976) as the fossiliferous sediments of the Kiel Sand Member (analogous to the Argenta section) instead of Antwerpen Sand Member, as suggested by these authors. As mentioned before in De Schutter \& Everaert (2020), Van den Bosch (1966) did notice, in contrast to De Meuter et al. (1976), a lithological boundary at $3.70 \mathrm{~m}$ below the top of the Miocene in the Kievitstraat (A.K.) section (referred to as Ploegstraat section; the temporary exposure was enclosed by both the Kievitstraat and Ploegstraat), analogous to the observations in the Argenta, Post X and Tweelingenstraat sections. The dinocyst assemblages (DN2) of the lower part of the Kievitstraat section also correspond with those of the Kiel Sand Member in other sections (Louwye et al., 2000; present study). Following our lithostratigraphical interpretation of the Kievitstraat section, biozone DN4 is recognized in the base of the overlying
Antwerpen Sand Member at the Kievitstraat section (Louwye et al., 2000), as in all known sections (Louwye et al., 2000, 2010; this study).

All fossiliferous horizons in the Kiel Sand Member are part of dinocyst biozone DN2. At the Argenta section, the base of the Kiel Sand Member was not reached. In a geothermal flushed drilling (DOV 1405-B420752), the contact between the Berchem Formation and the Boom Clay Formation was reached at $26 \mathrm{~m}$ below surface, with a break in lithology at $22 \mathrm{~m}$, presumably representing the transition between the Kiel Sand Member and the finer-grained, more clayey Edegem Sand Member. Following this interpretation, the Kiel Sand Member continues for at least $7 \mathrm{~m}$ below the articulated Glycymeris horizon. This makes the late Aquitanian dating of the articulated Glycymeris horizon (AR2) quite remarkable, since the subjacent Edegem Sand Member was not dated older than the earliest Burdigalian, or possibly latest Aquitanian (Louwye et al., 2000). Until now, biozone DN2a has not been recognised in Antwerp (Louwye et al., 2000). However, the dinocyst assemblage of the AR2 sample comprises taxa with Aquitanian LODs, like Homotryblium vallum (de Verteuil \& Norris, 1996; Munsterman \& Brinkhuis, 2004) and Hystrichokolpoma pseudooceanicum (Zevenboom, 1995; Munsterman \& Brinkhuis, 2004). Also, Thalassiphora pelagica was recorded, this taxon has a LOD in the earliest Burdigalian (Dybkjær \& Piasecki, 2010). Taxa with Aquitanian LODs were also recorded in the Kievitstraat section by Louwye et al. (2000), but considered as reworking from older successions. At the Argenta section, reworked palynomorphs are very rare and composed of Eocene to Oligocene taxa. No (such) reworking at all was noted in sample AR2. Hence the Aquitanian marker taxa are here considered as in situ. In addition, also the reinterpretation of the core sections in boreholes Weelde and ON-Mol-1 showed an Aquitanian age for the base of the Berchem Formation, respectively subdivided into Zone SNSM1 and SNSM2 (Munsterman \& Deckers, 2020, this volume). Zone SNSM1 was not reached in the Argenta section. Although the assemblage in sample AR2 contains typical late Aquitanian dinoflagellate cysts indicative for the DN2a Subzone, this classification does not seem to fit into the current framework of the Berchem Formation. According to Louwye et al. (2000) and Louwye (2005), the dinoflagellate cysts from the Edegem Sand Member, underlying the Kiel Sand Member in the Antwerp area, are indicative for the presence of 

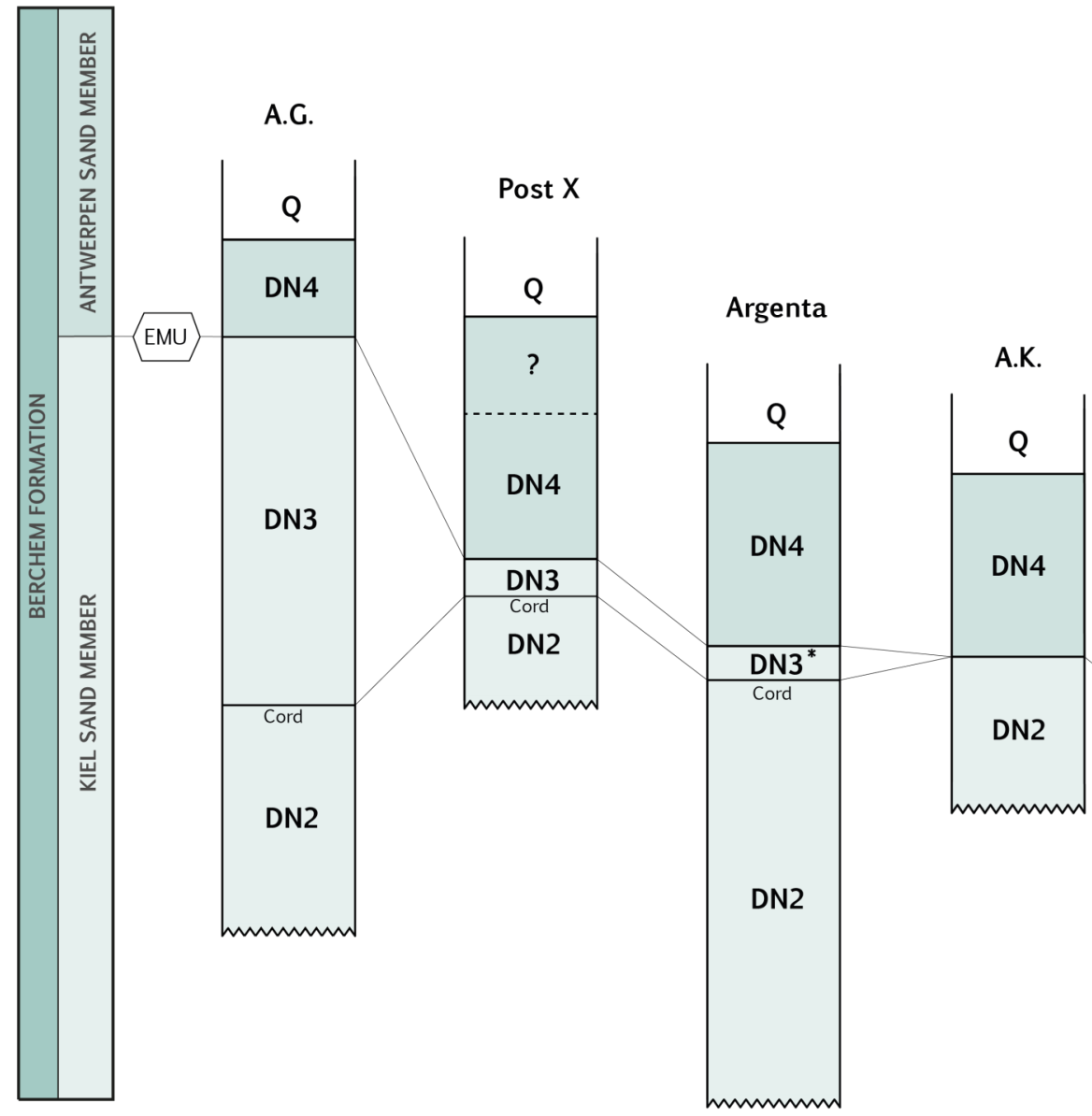

Figure 11. Bio- and lithostratigraphical correlations of the sections in the study area. Biostratigraphy A.G. and A.K. after Louwye et al. (2000), the lithostratigraphy of A.K. is reinterpreted in this study. DN zones with '*' are inferred from correlation with other samples. ? = The palynology of the Antwerpen Member above the central Glycymeris shell beds has not been studied. Cord = Cordiopsis horizon (see 6.4.). EMU = Early Miocene Unconformity, see Munsterman et al. (2019). Q = Quaternary.

the younger DN2b Subzone. Hence these interpretations are contradictory. Unfortunately, additional samples from the lower part of the Kiel Sand Member are lacking from the Argenta section to confirm the dating. Even though we have no indications for reworking within the assemblage affecting the dating of sample AR2, this cannot be fully excluded. Sample AR2 was obtained by opening a closed, articulated Glycymeris from the articulated Glycymeris horizon. In this horizon, most Glycymeris are still in life position, hence reworking of these articulated shells, or transportation from far is unlikely. This proves the importance for detailed palynological research in boreholes in the vicinity of the Argenta section, as the Berchem Formation continues for another 11 metres below the base of the pit. Such a complete succession of the lower Miocene has never been studied in the city of Antwerp.

Louwye et al. (2000) recognised both the younger part of the DN2 and the DN3 biozones of de Verteuil \& Norris (1996) in the Kiel Sand Member. Apart from sample AR2, all samples from the fossiliferous Kiel Sand Member horizons belong, as expected, to the younger parts of the DN2 biozone (earlymiddle Burdigalian). By the presence of rare specimens of Cordosphaeridium cantharellus in each sample, the DN2b subzone could be recognised. This taxon is also sporadically present by rare occurrences in the samples of the lower part of the Kiel Sand Member at the Berchem - Grote Steenweg (A.G.) section studied by Louwye et al. (2000).

One sample from the Kiel Sand Member (PX3) was examined from a non-fossiliferous unit (PX unit 3). This unit consists of $0.5 \mathrm{~m}$ of strongly bioturbated, grey, medium fine- to coarse-grained glauconitic sand with locally some dispersed, small sandstones, overlying the fossiliferous Cordiopsis horizon. It was also observed at the Argenta section (AR unit 9) but was absent at the Tweelingenstraat section. This unit was deposited during the middle-late Burdigalian, as biozone DN3 (Zone SNSM4) is recognized. Despite its limited thickness at the Post $\mathrm{X}$ and Argenta sections, biozone DN3 reached a thickness of up to 6 metres at the Berchem - Grote Steenweg (A.G.) section in the south of Antwerp (Louwye et al., 2000). Further north of the Argenta site, this biozone completely disappears, e.g. at the Kievitstraat (A.K.) section (Louwye et al., 2000), where also the Cordiopsis horizon seems absent (Van den Bosch, 1966; De Meuter \& Laga, 1976). Also, at the Tweelingenstraat section, the Cordiopsis horizon is mostly absent and its typical fossils and concretions are found reworked at the base of the Antwerpen Sand Member (Biozone DN4: Louwye et al., 2000; Louwye et al., 2010; this study). We observe a decrease in thickness of the DN3 biozone from the southwest to the north, where the erosive base of the Antwerpen Sand Member cuts deeper into the Kiel Sand Member and truncates more of its upper part (DN3) (Fig. 11). It is tempting to interpret the close relationship at the base of the Antwerpen Sand Member of tilting, erosion, renewed transgression and a peculiar short load casting phase as an expression of a single palaeogeographical rearrangement phase at that time.

The unconformity between the Antwerpen Sand Member and underlying Kiel Sand Member in the present temporary exposures can be associated with the Early Miocene Unconformity (EMU), a geographically extensive unconformity 
recognised in the Roer Valley Graben rift system, the Dutch northern offshore and adjacent areas in Germany and Denmark (Munsterman et al., 2019). The EMU associated hiatus is well documented in well Goirle, $50 \mathrm{~km} \mathrm{NE}$ of the study area, just across the Belgian-Dutch border, where biozone SNSM5-6 (Munsterman \& Brinkhuis, 2004) directly rests on SNSM3, hence biozone SNSM4, spanning c. $1.8 \mathrm{Ma}$, is missing (Munsterman et al., 2019, fig. 4). The stratigraphic position of this hiatus in well Goirle matches very well with the gap between the Antwerpen and Kiel Sand Members in the Antwerp area. The EMU is associated with the lithostratigraphic boundary between the Veldhoven Formation, Someren Member and the Groote Heide Formation in the Netherlands and the transition from the Köln to the Ville Formations in Germany (Munsterman et al., 2019).

The Kiel Sand Member was deposited in a shallow marine environment. A general fining upwards trend of the sand and the decrease of Paralecaniella spp. and increase of Spiniferites spp. show the ongoing transgression, with more restricted marine settings in the lower horizons (articulated Glycymeris horizon, Glycymeris-Cyrtodaria horizon) and more open marine settings (Brinkhuis, 1994; Powell et al., 1996) in the higher levels (Cordiopsis horizon). The preservation and taphonomy of the molluscs indicate a high energetic environment in which waves, currents and storms strongly influenced the palaeoenvironment. Periods of relatively low sedimentation rates facilitated encrustation and the establishment of drilling biota on the shells, as well as bioerosion of shark teeth and incipient formation of brown-grey phosphatic concretions. However, in the condensed Cordiopsis horizon, situated near the boundary between biozones DN2 and DN3, bioerosion on shark teeth and cetacean remains is almost lacking, which possibly indicates relatively higher sedimentation rates, before winnowing has concentrated the fossils.

The fossil fauna of the Kiel Sand Member is rich and diverse, and shows similarities with the fauna of the Antwerpen Sand Member, but also some interesting differences, e.g. the striking dominance of Isurus oxyrinchus over Carcharodon hastalis in the Kiel Sand Member, in contrast to the Carcharodon hastalis dominated Antwerpen Sand Member. Typical for the Kiel Sand Member, is the frequent infestation of Glycymeris by Maeandropolydora, a phenomenon that is only very rarely observed elsewhere in the Berchem Formation. An important mollusc fauna was found, mainly in the GlycymerisCyrtodaria horizon and a sandstone bed similar to that described by Herman \& Marquet (2007) from the Deurganckdok. Some mollusc species are reported for the first time from the Kiel Sand Member (Patinopecten brummelii, Venus multilamella s.l., Astarte goldfussi, Astarte radiata, Cubitostrea digitalina, Neopycnodonte indet.). Patinopecten brummelii and Haustator eryna proved to have a much longer range in the mollusc biostratigraphy of the Antwerp Miocene than previously known. Due to the presence of several mollusc index species (Glossus burdigalensis cypriniformis, Patinopecten brummelii, Cubitostrea digitalina, Haustator eryna), the Kiel Sand Member shows many similarities with the contemporaneous Houthalen Sand Member (Bolderberg Formation) in eastern Belgium.

The discussed fossiliferous horizons seem to be more or less laterally continuous in the studied area. This allows them to be used as references when interpreting future sections, as they offer important insights into the faunal succession during the early Miocene in the Antwerp area.

\section{Acknowledgements}

We would like to express our gratitude to several individuals, companies and institutions. To Groep Van Roey, Investar,
Besix, Soetaert and MBG for allowing access to their construction sites. To the Geological Survey of the Netherlands (TNO, Utrecht) for making the palynological analysis financially possible. To the reviewers: Noël Vandenberghe (KULeuven), Stephen Louwye (UGent), Frank Wesselingh (Naturalis, Leiden) and Jaap van der Voort (Ostercappeln) for their helpful suggestions, improving our paper substantially. To Geert De Borger (Niel), Walter Van Remoortel (Aartselaar), Djordy Rondelez (Izegem), Gino Mariën (Lede) and Guy van den Eeckhaut (Erpe-Mere) for their assistance in the field, access to their collections and/or technical support. To Stephane Knoll (Hemiksem) for collecting some large, additional sandstones. To Katrien De Nil (Vlaamse Overheid, Brussels) and Marleen De Ceuckelaire (BGD, Brussels) for their help with the DOV reference set and the storage of additional sediment samples. To Freddy van Nieulande (Nieuw en Sint-Joosland), Marcel Vervoenen (Aalst), Marijn Roosen (Tilburg) and Arie Janssen (Katwijk) for their useful comments on molluscs. To Alberto Collareta (Università di Pisa, Pisa) for his advice and important help with the identification of barnacles. To John Jagt (NHM, Maastricht) for his comments on invertebrates. To Olivier Lambert (RBINS, Brussels) for his help in identifying cetacean remains. To David Árpád (UNIDEB, Debrecen) for the determination of polychaet ichnofossils and to Kristiaan Hoedemakers (RBINS, Brussels) for stimulating discussions on the Berchem Formation.

\section{References}

Anthonissen, E., 2012. A new Miocene biostratigraphy for the northeastern North Atlantic: an integrated foraminiferal, bolboformid, dinoflagellate and diatom zonation. Newsletters on Stratigraphy, 45, 281-307. https://dx.doi.org/10.1127/00780421/2012/0025

Árpád, D., 2011. Bioeróziós nyomok késõ-oligocén (egri) korú Glycymeris vázmaradványokon. Malakológiai Tájékoztató, 29, 9-18.

Boekschoten, G.J., 1966. Shell borings of sessile epibiontic organisms as palaeo-ecological guides (with examples from the Dutch Coast). Palaeogeography, Palaeoclimatology, Palaeoecology, 2, 333-379. https://doi.org/10.1016/0031-0182(66)90023-X

Bor, T., Reinecke, T. \& Verschueren, S., 2012. Miocene Chondrichthyes from Winterswijk-Miste, the Netherlands. Palaeontos, 21, $136 \mathrm{p}$.

Brinkhuis, H., 1994. Late Eocene to Early Oligocene dinoflagellate cysts from the Priabonian (type-area, N-E Italy): biostratigraphy and paleoenvironmental interpretation. Palaeogeography, Palaeoclimatology, Palaeoecology, 107, 121-163. https:// doi.org/10.1016/0031-0182(94)90168-6

Bromley, R.G. \& D’Alessandro, A., 1983. Bioerosion in the Pleistocene of Southern Italy: ichnogenera Caulostrepsis and Maeandropolydora. Rivista Italiana di Paleontologia e Stratigrafia, 89, 283-309.

Buckeridge, J.S., Kočí, T., Gašparič, R. \& Kočová Veselská, M., 2020. Actinobalanus? sloveniensis (Thoracica, Balanoidea), a new species of cirripede from the Oligocene and Miocene of Slovenia that grew attached to wood substrates. Neues Jahrbuch für Geologie und Paläontologie - Abhandlungen, 296, 51-65. https:// dx.doi.org/10.1127/njgpa/2020/0902

Cadée, G.C., 1977. Bryozoa from the Late Miocene Mica Clay of Morsum Kliff, Sylt, Western Germany. Mededelingen van de Werkgroep voor Tertiaire en Kwartaire Geologie, 14, 43-50.

Cadée, C. \& Wesselingh, F., 2005. Van levend schelpdier naar Fossiele schelp: tafonomie van Nederlandse strandschelpen. Spirula, 343, 36-52.

Cappetta, H., 2012. Chondrichthyes: Mesozoic and Cenozoic Elasmobranchii: teeth. In Schultze, H.-P. (ed.), Handbook of Paleoichthyology, Vol. 3E. Friedrich Pfeil, München, 1-512.

Carrera-Parra, L.F., Fauchald, K. \& Gambi, M.C., 2011. Revision of the taxonomic status of Lysidice (Polychaeta, Eunicidae) in the Western Caribbean Sea with observation on species reproductive 
features and habitat preference. Italian Journal of Zoology, 78, 2740. https://doi.org/10.1080/11250003.2011.593850

Cleveringa, J., 2000. Reconstruction and modelling of Holocene coastal evolution of the Western Netherlands. Geologica Ultraiectina, 200 $1-198$.

Cogels, P., 1879. In Van Ertborn, O., (ed.), Notes sur les formations géologiques des environs d'Anvers. Bulletin de la Société géographique d'Anvers, 3, 346-350.

Crisp, D.J. \& Bourget, E., 1985. Growth in barnacles. Advances in Marine Biology, 22, 199-244. https://doi.org/10.1016/S0065-2881 (08)60052-8

Deckers, J. \& Louwye, S., 2019. A reinterpretation of the ages and depositional environments of the lower and middle Miocene stratigraphic records in a key area along the southern margin of the North Sea Basin. Geological Magazine, 156, 525-532. https:// doi.org/10.1017/S0016756817000991

De Ceuster, J., 1987. A little known odontaspid shark from the Antwerp Sand Member (Miocene, Hemmoorian) and some stratigraphical remarks on the shark-teeth of the Berchem Formation (Miocene, Hemmoorian) at Antwerp (Belgium). Mededelingen van de Werkgroep voor Tertiaire en Kwartaire Geologie, 24, 231-246.

De Meuter, F.J. \& Laga, P.G., 1976. Lithostratigraphy and biostratigraphy based on benthonic foraminifera of the Neogene deposits in Northern Belgium. Bulletin van de Belgische Vereniging voor Geologie/Bulletin de la Société belge de Géologie, $85,133-152$

De Meuter, F., Wouters, K. \& Ringele, A., 1976. Lithostratigraphy of Miocene sediments from temporary outcrops in the Antwerp City area. Professional Papers du Service géologique de Belgique, 3, 1-19.

De Nil, K., De Ceukelaire, M. \& Van Damme, M., 2020. A reference dataset for the Neogene lithostratigraphy in Flanders, Belgium. Geologica Belgica, 23/3-4, this volume. https://oi.org/10.20341/ gb. 2020.021

De Schepper, S. \& Head, M.J., 2008. Age calibration of dinoflagellate cyst and acritarch events in the Pliocene-Pleistocene of the eastern North Atlantic (DSDP Hole 610A). Stratigraphy, 5, 137-161.

De Schepper, S. \& Head, M.J., 2009. Pliocene and Pleistocene dinoflagellate cyst and acritarch zonation of DSDP Hole 610A, eastern North Atlantic. Palynology, 33, 179-218. https:// doi.org/10.2113/gspalynol.33.1.179

De Schutter, P., 2011. Carcharias vorax (Le Hon, 1871) (Chondrichthyes, Lamniformes), from the Miocene of Belgium: redescription and designation of a neotype and paraneotype. Geologica Belgica, 14, 175-192.

De Schutter, P. \& Everaert, S., 2020. A megamouth shark (Lamniformes: Megachasmidae) in the Burdigalian of Belgium Geologica Belgica, 23/3-4, this volume. https://doi.org/10.20341/ gb.2020.001

de Verteuil, L. \& Norris, G., 1996. Miocene dinoflagellate stratigraphy and systematics of Maryland and Virginia. Micropaleontology, 42, Supplement, 1-172. https://doi.org/10.2307/1485926

Diedrich, C.G., 2012. Palaeoecology, facies and stratigraphy of shallow marine macrofauna from the Upper Oligocene (Palaeogene) of the southern Pre-North Sea Basin of Astrup (NW Germany). Central European Journal of Geosciences, 4, 163-187. https:// doi.org/10.2478/s13533-011-0051-1

Doyle, P., Mather, A.E., Bennett, M.R. \& Bussell, M.A., 1997. Miocene barnacle assemblages from southern Spain and their palaeoenvironmental significance. Lethaia, 29, 267-274. https:// doi.org/10.1111/j.1502-3931.1996.tb01659.x

Dulai, A., 2013. Sporadic Miocene brachiopods in the Naturalis Biodiversity Center (Leiden, the Netherlands): Records from the Mediterranean, the North Sea, and the Atlantic Ocean. Fragmenta Palaeontologica Hungarica, 30, 15-51. https://doi.org/10.17111/ FragmPalHung.2016.33.65

Dybkjær, K. \& Piasecki, S., 2010. Neogene dinocyst zonation for the eastern North Sea Basin, Denmark. Review of Palaeobotany and
Palynology, 161, 1-29. https://doi.org/10.1016/ j.revpalbo.2010.02.005

Elsik, W.C., 1977. Paralecaniella indentata (Defl. \& Cooks, 1955) Cookson \& Eisenack 1970 and allied dinocysts. Palynology, 1, 95102. https://doi.org/10.1080/01916122.1977.9989152

Everaert, S., De Schutter, P., Mariën, G., Cleemput, G., Van Boeckel, J., Rondelez, D. \& Bor, T., 2019. Een vroeg-miocene fauna uit het Zand van Kiel (Formatie van Berchem) bij Post $\mathrm{X}$ in Berchem (Antwerpen). Afzettingen WTKG, 40, 83-100

Fensome, R.A., Williams, G.L., \& MacRae, R.A., 2019. The Lentin and Williams Index of fossil dinoflagellates 2019 edition. AASP Contributions Series, 50, $1173 \mathrm{p}$.

Fürsich, F.T. \& Oschmann, W., 1993. Shell beds as tools in basin analysis: the Jurassic of Kachchh, western India. Journal of the Geological Society, 150, 169-185. https://doi.org/10.1144/ gsjgs. 150.1.0169

Gaemers, P.A.M. \& De Ceuster, J., 1978. Een interessante ontsluiting in Miocene afzettingen te Wilrijk bij Antwerpen (België). Mededelingen van de Werkgroep voor Tertiaire en Kwartaire Geologie, 15, 67-72

Glibert, M., 1945. Faune malacologique du Miocène de la Belgique : I. Pélécypodes. Mémoires du Musée royal d'Histoire naturelle de Belgique, 103, 1-266.

Glibert, M., 1952. Faune malacologique du Miocène de la Belgique : II. Gastropodes. Mémoires de l'Institut royal des Sciences naturelles de Belgique, 121, 1-197.

Glibert, M., 1958. Tableau stratigraphique des Mollusques du Néogène de la Belgique. Bulletin de l'Institut royal des Sciences naturelles de Belgique, 34/32, 1-20.

Herman, J. \& Marquet, R., 2007. Le Miocène du Deurganckdok à Doel. Memoirs of the Geological Survey of Belgium, 54, 1-149.

Hoedemakers, K. \& Dufraing, L., 2018. Een profiel bij Posthofbrug (Antwerpen). Afzettingen WTKG, 39, 65-80.

Holme, N.A., 1961. Shell form in Venerupis rhomboides. Journal of the Marine Biological Association of the United Kingdom, 41, 705722. https://doi.org/10.1017/S002531540001626X

Jagt, J., 2016a. Stekelhuidigen (Echinodermata - Echinoidea, Asteroidea, Crinoidea en Ophiuroidea) van Winterswijk-Miste Afzettingen WTKG, 37, 31-49.

Jagt, J., 2016b. Kreeftachtigen (Ostracoda, Thoracica, Caridea, Axiidea, Anomura en Brachyura) van Winterswijk-Miste. Afzettingen WTKG, 37, 54-66.

Janse, A. \& Langeveld, B., 2014. De bivalve Cordiopsis polytropa (Anderson, 1958) s.l. van Maasvlakte 2 en iets over Cordiopsis Afzettingen WTKG, 35, 101-107.

Janssen, A.W., 1984. Mollusken uit het Mioceen van WinterswijkMiste: een inventaris, met beschrijving en afbeelding van alle aangetroffen soorten. Koninklijke Nederlandse Natuurhistorische Vereniging, Nederlandse Geologische Vereniging, Rijksmuseum van Geologie en Mineralogie, Leiden, $451 \mathrm{p}$

Janssen, N. \& Dammers, G., 2008. Sample processing for the preQuaternary palynology. Internal TNO report, $9 \mathrm{p}$.

Janssen, A.W. \& Van der Mark, D., 1968. Einleitung zu den Beiträgen zur Kenntnis der Molluskenfauna des jüngeren Tertiärs im Nordseebecken. Basteria, 32, 76-82.

Johnson, H.D. \& Baldwin, C.T., 1986. Shallow siliciclastic seas. In Reading, H.G. (ed.), Sedimentary Environments and Facies. $2^{\text {nd }}$ ed Blackwell Scientific Publications, Oxford, 229-282.

Köthe, A., 2003. Dinozysten-Zonierung im Tertiär Norddeutschlands. Revue de Paléobiologie, 22, 895-923.

Köthe, A., 2007. Cenozoic biostratigraphy from the German North Sea sector (G-11-1 borehole, dinoflagellate cysts, calcareous nannoplankton). Zeitschrift der Deutschen Gesellschaft für Geowissenschaften, 158, 287-327. https://dx.doi.org/10.1127/18601804/2007/0158-0287

Köthe, A., Gaedicke, C. \& Lutz, R., 2008. Erratum: The age of the MidMiocene Unconformity (MMU) in the G-11-1 borehole, German North Sea sector. Zeitschrift der Deutschen Gesellschaft für 
Geowissenschaften, 159, 687-689. https://dx.doi.org/10.1127/18601804/2008/0159-0687

Kuhlmann, G., Langereis, C.G., Munsterman, D.K., Van Leeuwen, R.J., Verreussel, R., Meulenkamp, J.E. \& Wong, Th.E., 2006. Chronostratigraphy of Late Neogene sediments in the southern North Sea Basin and paleoenvironmental interpretations. Palaeogeography, Paleoclimatology, Palaeoecology, 239, 426-455. http://dx.doi.org/10.1016/j.palaeo.2006.02.004

Laga, P., Louwye, S. \& Mostaert, F., 2006. Disused Neogene and Quaternary regional stages from Belgium: Bolderian, Houthalenian, Antwerpian, Diestian, Deurnian, Kasterlian, Kattendijkian, Scaldisian, Poederlian, Merksemian and Flandrian. Geologica Belgica, 9, 215-224.

Lambert, O., 2004. Systematic revision of the Miocene long-snouted dolphin Eurhinodelphis longirostris du Brus, 1872 (Cetacea, Odontoceti, Eurhinodelphinidae). Bulletin de l'Institut royal des Sciences naturelles de Belgique, Sciences de la Terre, 74, 147-174.

Le Hon, H., 1871. Préliminaires d'un mémoire sur les poissons tertiaires de Belgique. H. Merzbach, Bruxelles, $15 \mathrm{p}$.

Leriche, M., 1926. Les poissons néogènes de la Belgique. Mémoires du Musée royal d'Histoire naturelle de Belgique, 32, 367-472.

Louwye S., 2000. Dinoflagellate cysts and acritarchs from the Miocene Zonderschot Sands, northern Belgium: stratigraphic significance and correlation with contiguous areas. Geologica Belgica, 3, 55-65. https://doi.org/10.20341/gb.2014.023

Louwye S., 2002. Dinoflagellate cyst biostratigraphy of the Upper Miocene Deurne Sands (Diest Formation) of northern Belgium, southern North Sea Basin. Geological Journal, 37, 55-67. https:// doi.org/10.1002/gj. 900

Louwye, S., 2005. The Early and Middle Miocene transgression at the southern border of the North Sea Basin (northern Belgium). Geological Journal, 40, 441- 456. https://doi.org/10.1002/gj.1021

Louwye, S. \& Mertens, K., 2007. Dinoflagellate cysts of a lower Miocene sequence at Doel. In Herman, J. \& Marquet, R., Le Miocène du Deurganckdok à Doel. Memoirs of the Geological Survey of Belgium, 54, 53-54.

Louwye, S., De Coninck, J. \& Verniers, J., 2000. Shallow marine Lower and Middle Miocene deposits at the southern margin of the North Sea Basin (northern Belgium): dinoflagellate cyst biostratigraphy and depositional history. Geological Magazine, 137, 381-394. https://doi.org/10.1017/S0016756800004258

Louwye, S., Marquet, R., Bosselaers, M. \& Lambert, O., 2010. Stratigraphy of an early-middle Miocene sequence near Antwerp in Northern Belgium (Southern North Sea Basin). Geologica Belgica, 13, 269-284.

Louwye, S., Deckers, J., Verhaegen, J., Adriaens, R. \& Vandenberghe, N., 2020. A review of the lower and middle Miocene of northern Belgium. Geologica Belgica, 23/3-4, this volume. https:// doi.org/10.20341/gb.2020.010

Mandic, O. \& Harzhauser, M., 2003. Molluses from the Badenian (Middle Miocene) of the Gaindorf Formation (Alpine Molasse Basin, NE Austria). Taxonomy, Paleoecology and Biostratigraphy. Annalen des Naturhistorischen Museums in Wien, 104 A, 85-127.

Mandic, O., Harzhauser, M. \& Roetzel, R., 2004. Taphonomy and sequence stratigraphy of spectacular shell accumulations from the type stratum of the Central Paratethys stage Eggenburgian (Lower Miocene, NE Austria). Courier Forschungsinstitut Senckenberg, 246, 69-88.

Marquet, R., 1984. Gids voor de ichnofossielen van België. Publicatie van de Belgische Vereniging voor Paleontologie, 4, 1-71.

Marquet, R., 1991. Recent temporary exposures of the Antwerpen Sands in the Antwerp City area: stratigraphy and fauna. Contributions to Tertiary and Quaternary Geology, 28, 9-12.

Menesini, E., 1965. Caratteri morfologici e struttura microscopica di alcune specie di Balani neogenici e quaternari. Palaeontographia Italica, 59 (N.S. 29), 83-129.

Menesini, E., 1982. Actinobalanus stellaris (BROCCHI) (Cirripedia, Thoracica). Variabilità morfologica e strutturale in funzione dell'ambiente. Atti della Società Toscana di Scienze Naturali, Memorie Serie A, 89, 115-139.

Menesini, E., 1984. Distribution of some Mediterranean species of Balanomorpha (Cirripedia, Thoracica) from the Tertiary to the Actual. Atti della Società Toscana di Scienze Naturali, Memorie Serie A, 91, 291-303.

Mikuláš, R. \& Pek, I., 1996. Borings in the oyster shells from the Badenian at Česká Třebová and its neighbourhood (Eastern Bohemia, Czech Republic). Journal of the Czech Geological Society, 41, 97-104.

Mikuž, V. \& Gašparič, R., 2014. Nekaj redkih fosilov iz Slovenskih goric (Some rare fossils from Slovenske gorice, Slovenia). Geologija, 57, 155-166. https://doi.org/10.5474/geologija.2014.013

Moerdijk, P.W., Janssen, A.W., Wesselingh, F.P., Peeters, G.A., Pouwer, R., Van Nieulande, F.A.D., Janse, A.C., Van der Slik, L., Meijer, T., Rijken, R., Cadée, G.C., Hoeksema, D., Doeksen, G., Bastemeijer, A., Strack, H., Vervoenen, M. \& Ter Poorten, J.J., 2010. De fossiele schelpen van de Nederlandse kust. Nederlands Centrum voor Biodiversiteit Naturalis, Leiden, 294 p.

Moorkens, T., 1969. Excursions in some temporary outcrops 1966-1969 of the Neogene succession of Antwerp. University of Ghent, Ghent, $45 \mathrm{p}$.

Moths, H., Albrecht, F. \& Stein, G., 2010. Die Molluskenfauna (Hemmoorium, Untermiozän) aus der Kiesgrube Krinke bei Werder (Nordwest-Niedersachsen). Palaeofocus, 3, $155 \mathrm{p}$.

Munsterman, D.K. \& Brinkhuis, H., 2004. A southern North Sea Miocene dinoflagellate cyst zonation. Netherlands Journal of Geosciences / Geologie en Mijnbouw, 83, 267-285. https:// doi.org/10.1017/S0016774600020369

Munsterman, D. \& Deckers, J., 2020. The Oligocene/Miocene boundary in the ON-Mol-1 and Weelde boreholes along the southern margin of the North Sea Basin, Belgium. Geologica Belgica, 23/3-4, this volume. https://doi.org/10.20341/gb.2020.007

Munsterman, D.K., ten Veen, J.H, Menkovic, A., Deckers, J., Witmans, N., Verhaegen, J., Kerstholt-Boegehold S.J., van de Ven, T \& Busschers, F.S., 2019. An updated and revised stratigraphic framework for the Miocene and earliest Pliocene strata of the Roer Valley Graben and adjacent blocks. Netherlands Journal of Geosciences, 98, e8. https://doi.org/10.1017/njg.2019.10

Nichols, G., 2009. Sedimentology and Stratigraphy. $2^{\text {nd }}$ ed. WileyBlackwell, Chichester, $432 \mathrm{p}$.

Nyst, H. \& Westendorp, G.D., 1839. Nouvelles recherches sur les coquilles fossiles de la Province d'Anvers. Bulletin de l'Académie royale des Sciences et Belles-Lettres de Bruxelles, 6/2, 393-414.

Ogg, J.G., Ogg, G. \& Gradstein, F.M., 2016. A Concise Geologic Time Scale. Elsevier, Amsterdam, 240 p. https://doi.org/10.1016/C2009-0 $-64442-1$

Powell, A.J., 1992. Dinoflagellate cysts of the Tertiary System. In Powell, A.J. (ed.), A Stratigraphic Index of Dinoflagellate Cysts. Springer, Dordrecht, 155-272.

Powell, A.J., Brinkhuis, H. \& Bujak, J.P., 1996. Upper PaleoceneLower Eocene dinoflagellate cyst sequence biostratigraphy of southeast England. Geological Society, London, Special Papers, 101, 145-183. https://doi.org/10.1144/GSL.SP.1996.101.01.10

Purchon, R.D., 1939. The effect of the environment upon the shell of Cardium edule. Proceedings of the Malacological Society of London, 23, 256-267. https://doi.org/10.1093/ oxfordjournals.mollus.a064364

Reinecke, T., Louwye, S., Havekost, U. \& Moths, H., 2011. The Elasmobranch Fauna of the Late Burdigalian, Miocene, at WerderUesen, Lower Saxony, Germany and its relationships with Early Miocene Faunas in the North Atlantic, central Paratethys and Mediterranean. Palaeontos, 20, $170 \mathrm{p}$.

Rogalla, N.S. \& Amler, M.R.W., 2007. Statistic approach on taphonomic phenomena in shells of Glycymeris glycymeris (Bivalvia: Glycymerididae) and its significance in the fossil record. Paläontologische Zeitschrift, 81, 334-355. https://doi.org/10.1007/ BF02990183 
Schwarzhans, W., 2010. The Otoliths from the Miocene of the North Sea Basin. Backhuys Publishers, Leiden \& Margraf Publishers, Weikersheim, $352 \mathrm{p}$.

Stein, G., Moths, H., Albrecht, F., Havekost, U. \& Fehse, D., 2016. Revision der Miozänen Molluskenfauna (Hemmoorium) von Werder bei Achim (Nordwest-Niedersachsen). Palaeofocus, 5, $289 \mathrm{p}$.

Studencka, B., 1986. Bivalves from the Badenian (Middle Miocene) marine sandy facies of Southern Poland. Palaeontologia Polonica, $47,3-128$.

Thomas, R.D.K., 1975. Functional morphology, ecology, and evolutionary conservatism in the Glycymerididae. Palaeontology, $18,217-254$

Van Beneden, P.J., 1865. Recherches sur les ossements provenant du Crag d'Anvers : les Squalodons. Mémoires de l'Académie royale des Sciences, des Lettres et des Beaux-Arts de Belgique, 35, 3-85.

Van den Bosch, M., 1966. De ontsluiting te Antwerpen - Ploegstraat. Mededelingen van de Werkgroep voor Tertiaire en Kwartaire Geologie, 3, 17-18.

Van den Bosch, M., Cadée, M.C. \& Janssen, A.W., 1975. Lithostratigraphical and biostratigraphical subdivision of Tertiary deposits (Oligocene-Pliocene) in the Winterswijk-Almelo region (eastern part of the Netherlands). Scripta Geologica, 29, 1-167.

Vandenberghe, N., Laga, P., Steurbaut, E., Hardenbol, J. \& Vail, P.R., 1998. Tertiary sequence stratigraphy at the southern border of the North Sea Basin in Belgium. In de Graciansky, P.-C., Hardenbol, J., Jacquin, T. \& Vail, P.R. (eds), Mesozoic and Cenozoic Sequence Stratigraphy of European Basins. Society for Sedimentary Geology (SEPM), Special Publication, 60, 119-154. https://doi.org/10.2110/ pec.98.02.0119

Van der Mark, D., 1965. De samenstelling en het ontstaan van de Zanden van Edegem bij de E3 - tunnel te Antwerpen, in het bijzonder van de onderste lagen. Mededelingen van de Werkgroep voor Tertiaire en Kwartaire Geologie, 2, 47-61.

Vervoenen, M., 1995. Taphonomy of some Cenozoic Seabeds from the Flemish Region, Belgium. Belgische Geologische Dienst, Professional paper, 1994/5, 272, $115 \mathrm{p}$.

Welton, J., 2015. The marine fish fauna of the Middle Pleistocene Port Orford Formation and Elk River Beds, Cape Blanco, Oregon. New Mexico Museum of Natural History and Science Bulletin, 66, 1-45.

Wilson, M.A. \& Palmer, T.J., 1992. Hardgrounds and hardground faunas. University of Wales, Aberystwyth, Institute of Earth Studies Publications 9, 1-131.

Zevenboom, D., 1995. Dinoflagellate cysts from the Mediterranean Late Oligocene and Miocene. Unpublished Ph.D. Thesis, University of Utrecht, Utrecht, $221 \mathrm{p}$.

Zullo, V.A. \& Perreault, R.T., 1989. Review of Actinobalanus moroni (Cirripedia, Archaeobalanidae), with the description of new Miocene species from Florida and Belgium. Tulane Studies in Geology and Paleontology, 22, 1-12. 


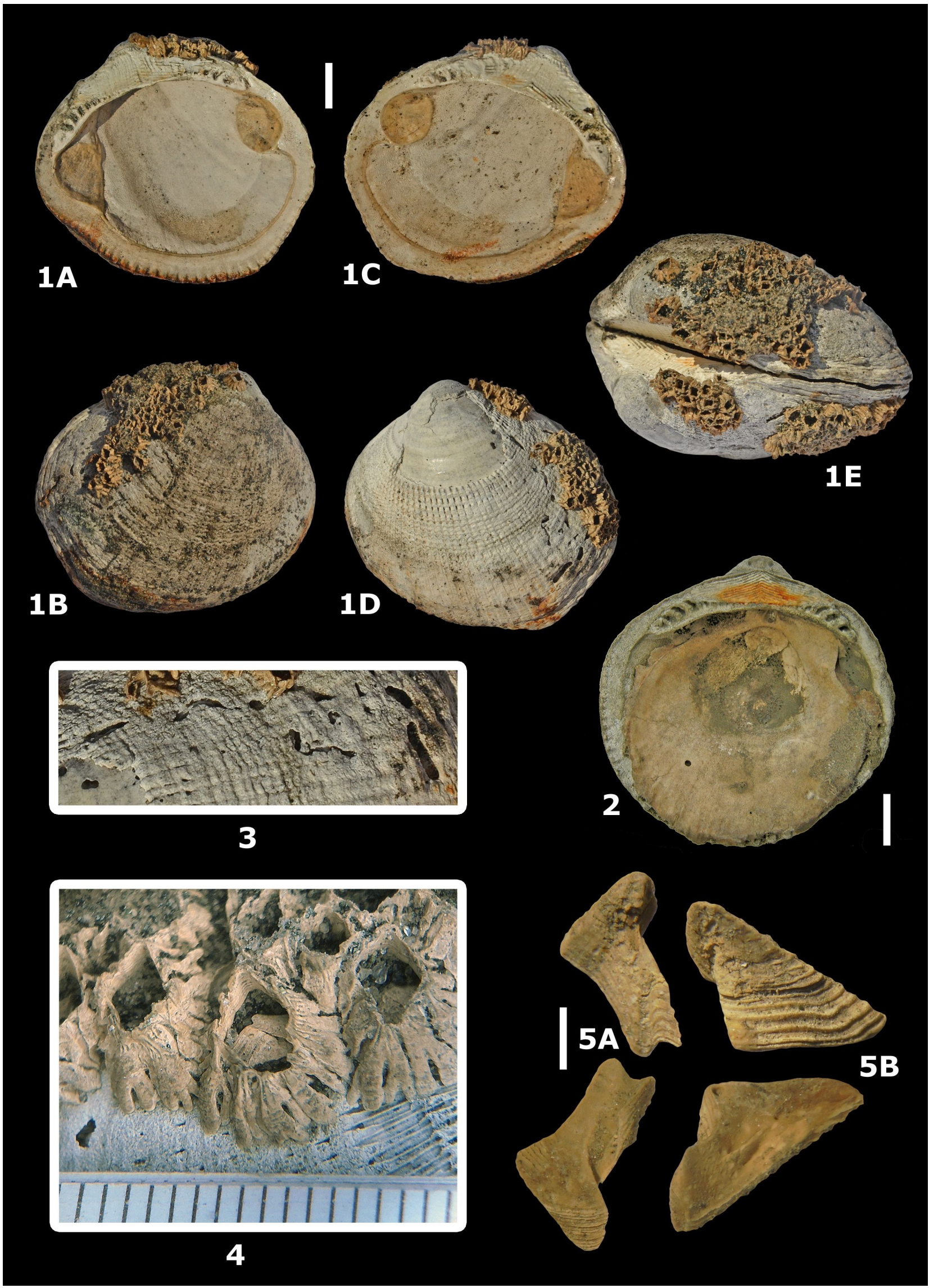

Plate 1. Palaeontology and taphonomy of the articulated Glycymeris horizon (Kiel Sand Member). 1. Articulated Glycymeris baldii Glibert \& Van de Poel, 1965 encrusted by Balanus (s.s.) aff. stellaris (Brocchi, 1814). A. Right valve, interior view; B. Right valve, exterior view; C. Left valve, interior view; D. Left valve, exterior view; E. side view. Kiel Sand Member, articulated Glycymeris horizon, Argenta unit 2. IRSNB 7683. Scale bar $10 \mathrm{~mm}$. 2. Hinnites ercolanianus Cocconi, 1873 attached to the interior side of a Glycymeris. Kiel Sand Member, articulated Glycymeris horizon, Argenta unit 2. IRSNB 7682. Scale bar $10 \mathrm{~mm}$. 3. Detail of the left Glycymeris valve. Borings of Maeandropolydora sulcans Voigt, 1965. Kiel Sand Member, articulated Glycymeris horizon, Argenta unit 2. IRSNB 7683. 4. Balanus (s.s.) aff. stellaris (Brocchi, 1814) with terga and scuta in life position. Kiel Sand Member, articulated Glycymeris horizon, Argenta unit 2. IRSNB 7684. 5. Detail of A. tergum and B. scutum. Kiel Sand Member, articulated Glycymeris horizon, Argenta unit 2. IRSNB 7684. Coll. RBINS. Scale bar $1 \mathrm{~mm}$. 


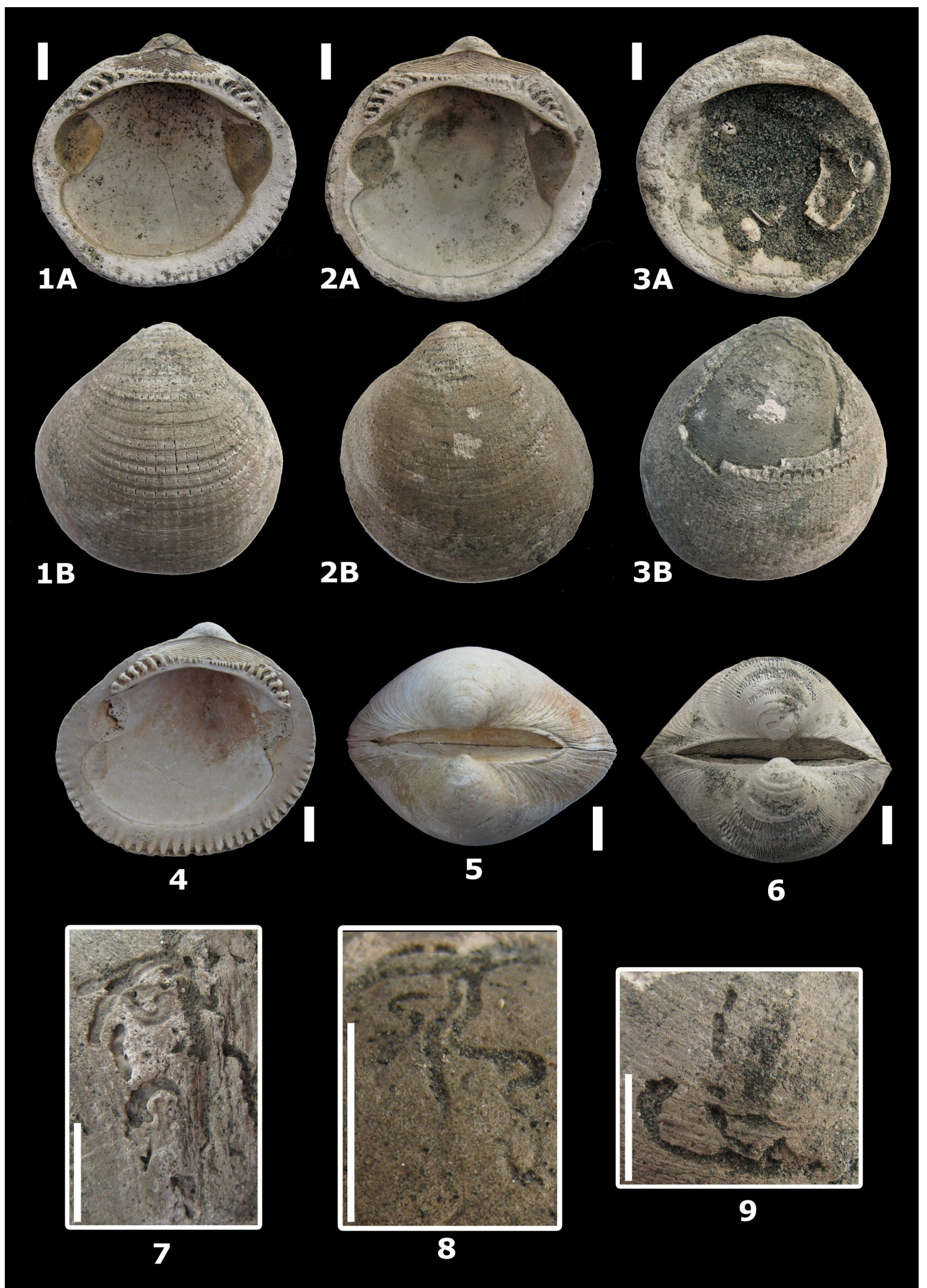

Plate 2. Palaeontology and taphonomy of the Glycymeris-Cyrtodaria horizon (Kiel Sand Member). 1. A-B. First abrasion stage: no significant abrasion. Kiel Sand Member, Glycymeris-Cyrtodaria horizon, Argenta unit 4. Coll. SE. Scale bar $10 \mathrm{~mm}$. 2. Second abrasion stage: A. erosion of the crenate margin (interior side) \& B. slightly abraded umbonal region, exposing the reticulate pattern (exterior side). Kiel Sand Member, GlycymerisCyrtodaria horizon, Argenta unit 4. Coll. SE. Scale bar $10 \mathrm{~mm}$. 3. Third abrasion stage: A. erosion of the crenate margin (interior side) \& B. deep layers of the outer shell material in the umbonal region are missing (exterior side). Kiel Sand Member, Glycymeris-Cyrtodaria horizon, Argenta unit 4. Coll. SE. Scale bar $10 \mathrm{~mm}$. 4. Glycymeris baldii Glibert \& Van de Poel, 1965. Antwerpen Sand Member, Militair Hospitaal exposure, correlated with Argenta unit 14. Coll. SE. Scale bar $10 \mathrm{~mm}$. 5. Articulated Glycymeris baldii Glibert \& Van de Poel, 1965. Antwerpen Sand Member, Militair Hospitaal exposure, correlated with Argenta unit 14. Coll. SE. Scale bar $10 \mathrm{~mm}$. 6. Articulated Glycymeris baldii Glibert \& Van de Poel, 1965. Kiel Sand Member, sandstone horizon, Argenta unit 6. Coll. SE. Scale bar $10 \mathrm{~mm}$. 7. Polychaet borings on Glycymeris: Maeandropolydora sulcans Voigt, 1965. Kiel Sand Member, Glycymeris-Cyrtodaria horizon, Argenta unit 4. Coll. SE. Scale bar $10 \mathrm{~mm}$. 8. Polychaet borings on Glycymeris: Caulostrepsis taeniola Clarke, 1908. Kiel Sand Member, Glycymeris-Cyrtodaria horizon, Argenta unit 4. Coll. SE. Scale bar 10 mm. 9. Polychaet borings on Glycymeris: Maeandropolydora decipiens Voigt, 1965. Kiel Sand Member, Glycymeris-Cyrtodaria horizon, Argenta unit 4. Coll. SE. Scale bar $10 \mathrm{~mm}$. 


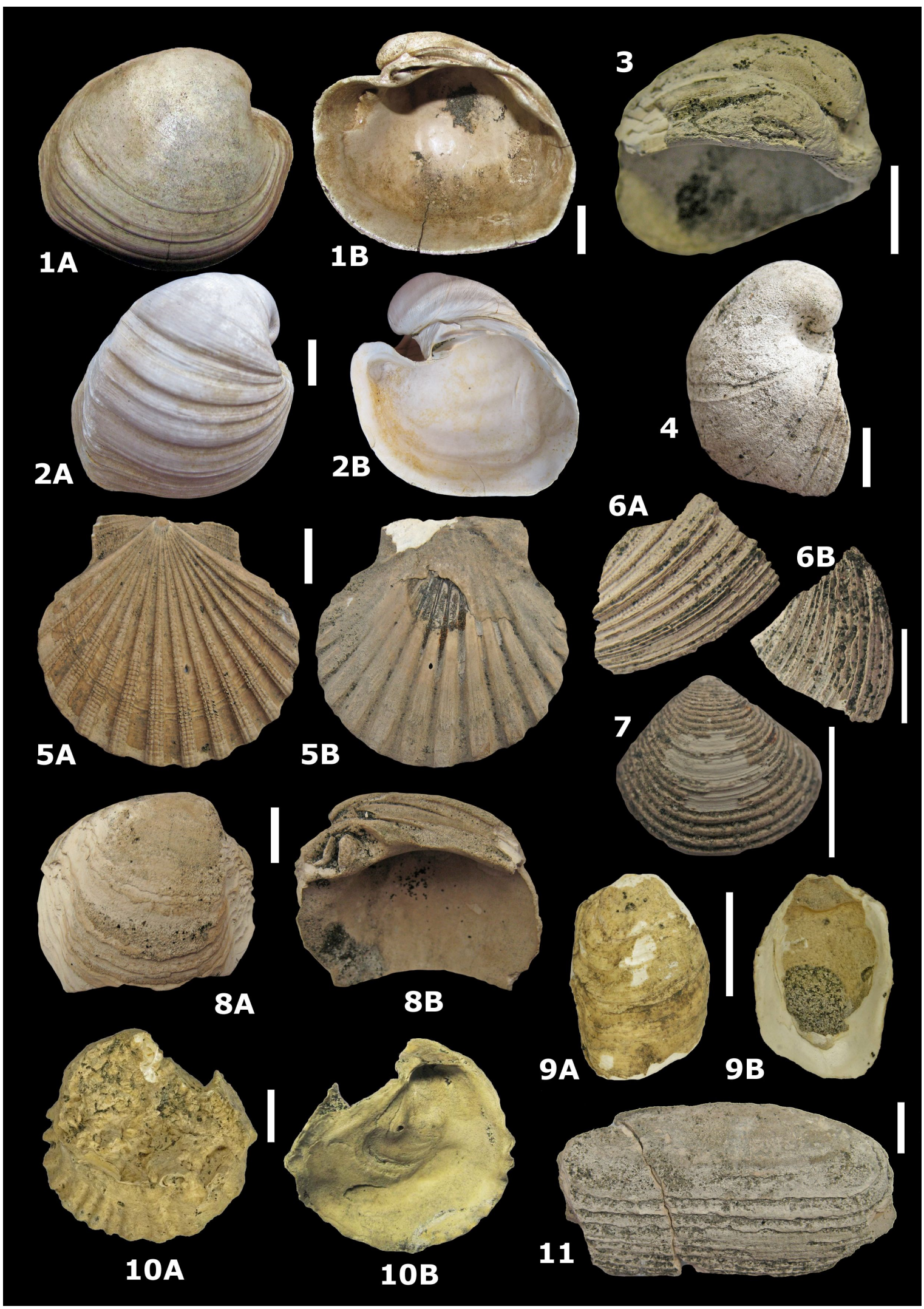

Plate 3. Palaeontology and taphonomy of the Glycymeris-Cyrtodaria horizon (Kiel Sand Member). 1A-B. Glossus burdigalensis cypriniformis (Nyst in Dewalque, 1868). Berchem Formation, stratigraphic level unknown, R1 construction 1966 (Antwerp). Coll. NBC (leg. F.A.D. Van Nieulande). Scale bar $10 \mathrm{~mm}$. See Herman \& Marquet (2007, plate 37) for additional comparison material. 2A-B. Glossus lunulatus lunulatus (Nyst, 1835). Antwerpen Sand Member, Militair Hospitaal outcrop, correlated with Argenta unit 14. Coll. SE. Scale bar 10 mm. 3. Glossus burdigalensis cypriniformis (Nyst in Dewalque, 1868). Fragment. Kiel Sand Member, Glycymeris-Cyrtodaria horizon, Tweelingenstraat unit 2. Coll. SE. Scale bar $10 \mathrm{~mm}$. 4. Glossus burdigalensis cypriniformis (Nyst in Dewalque, 1868). Fragment. Kiel Sand Member, Glycymeris-Cyrtodaria horizon, Argenta unit 4. Coll. SE. Scale bar $10 \mathrm{~mm}$. 5A-B. Patinopecten brummelii (Nyst, 1864). Kiel Sand Member, Glycymeris-Cyrtodaria horizon, Argenta unit 4. Coll. SE. Scale bar 10 mm. 6A-B. Venus multilamella s.l. Lamarck, 1818. Fragments. Kiel Sand Member, Glycymeris-Cyrtodaria horizon, Argenta unit 4. Coll. SE. Scale bar $10 \mathrm{~mm}$. 7. Astart radiata Nyst \& Westendorp, 1839. Kiel Sand Member, Glycymeris-Cyrtodaria horizon, Argenta unit 4. Coll. SE. Scale bar 5 mm. 8A-B. Cordiopsis polytropa nysti (d'Orbigny, 1852). Kiel Sand Member, Glycymeris-Cyrtodaria horizon, Argenta unit 4. Coll. SE. Scale bar 10 mm. 9A-B. Neopycnodonte indet. Kiel Sand Member, Glycymeris-Cyrtodaria horizon, Argenta unit 4. Coll. SE. Scale bar 10 mm. 10A-B. Cubitostrea digitalina (Eichwald, 1830). Kiel Sand Member, Glycymeris-Cyrtodaria horizon, Argenta unit 4. Coll. SE. Scale bar 10 mm. 11. Cytrodaria angusta (Nyst \& Westendorp, 1839). Kiel Sand Member, Glycymeris-Cyrtodaria horizon, Argenta unit 4. Coll. SE. Scale bar $10 \mathrm{~mm}$. 


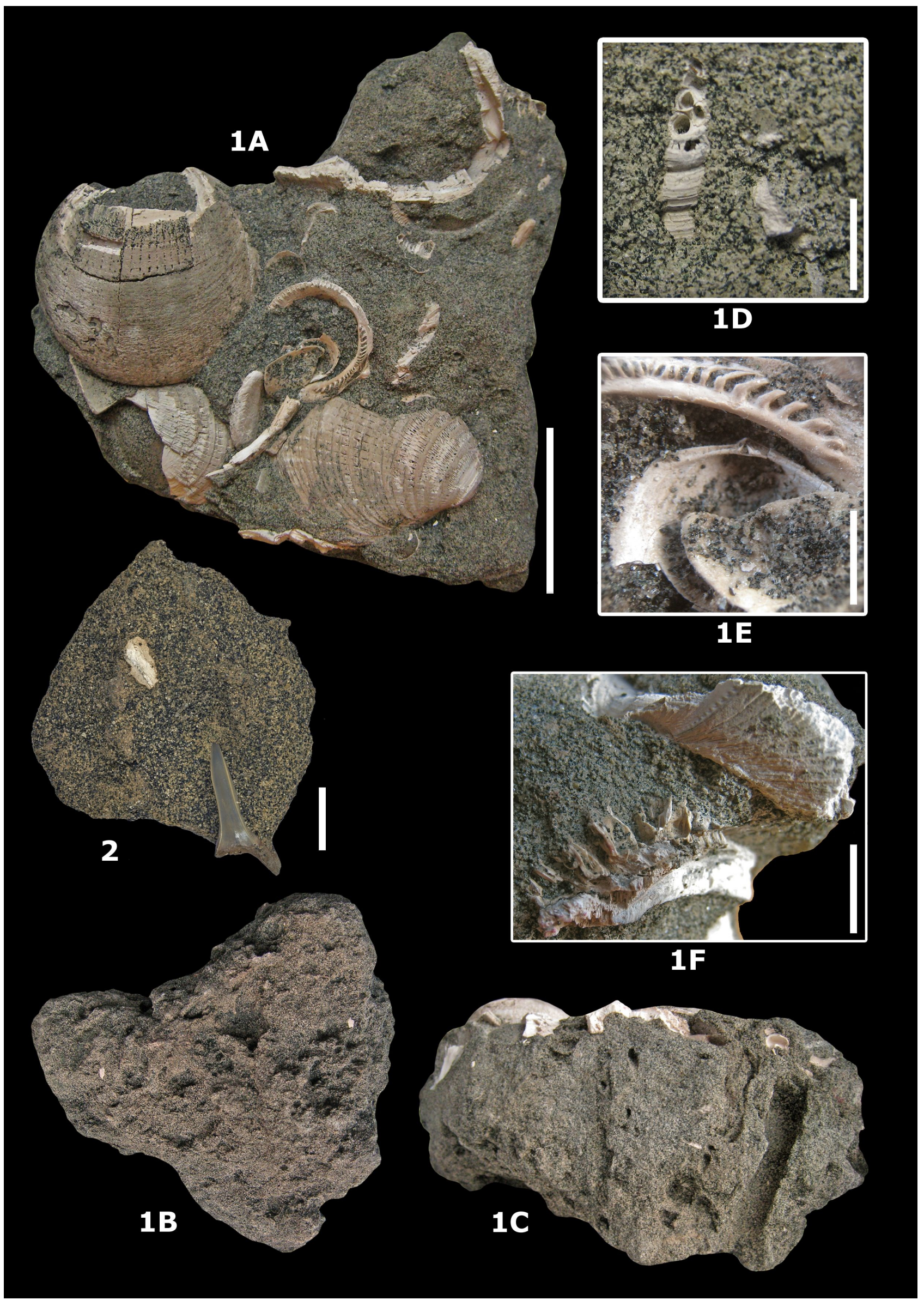

Plate 4. Palaeontology and taphonomy of the sandstone horizon (Kiel Sand Member). 1. Lithification IRSNB 7679. Argenta unit 6. Dimensions: $16 \mathrm{~cm}$ x $17 \mathrm{~cm}$ x $8 \mathrm{~cm}$. 1A. Top view, dominated by Glycymeris baldii Glibert \& Van de Poel, 1965. Scale bar $50 \mathrm{~mm}$. 1B. Bottom view, less delimited than the top due to bioturbation. 1C. Side view, with a decapod burrow starting from the bottom. 1D. Detail of top view: Haustator eryna (d'Orbigny, 1852). Scale bar $5 \mathrm{~mm}$. 1E. Detail of top view: Lucinoma borealis (Linnaeus, 1767). Scale bar $5 \mathrm{~mm}$. 1F. Detail of top view: Glycymeris fragment encrusted by barnacles. Scale bar $5 \mathrm{~mm}$. 2. Small lithification with a tooth of Isurus oxyrinchus Rafinesque, 1810. Tweelingenstraat unit 3. Coll. SE. Scale bar $10 \mathrm{~mm}$. 


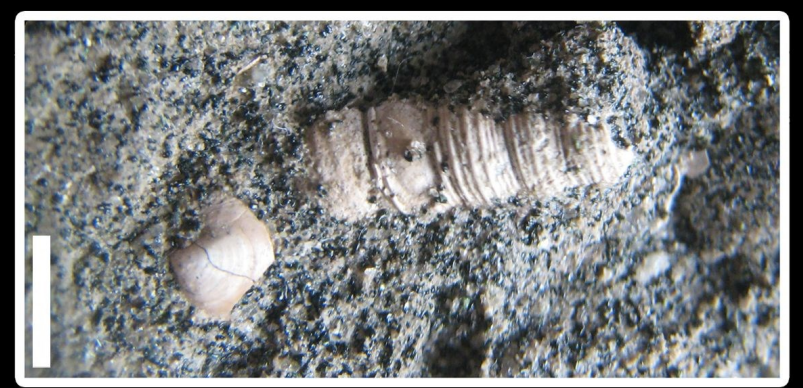

1B

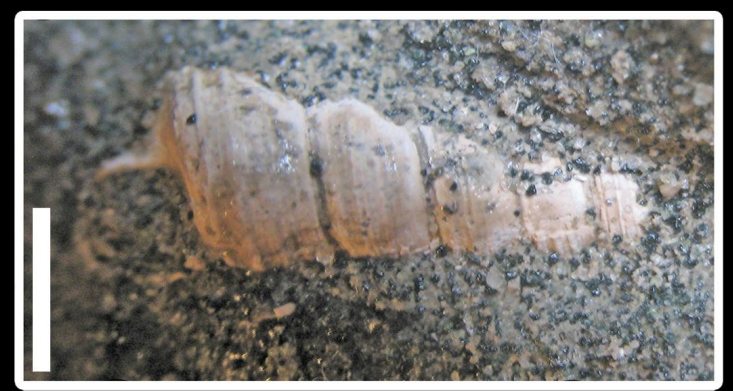

$1 \mathrm{C}$

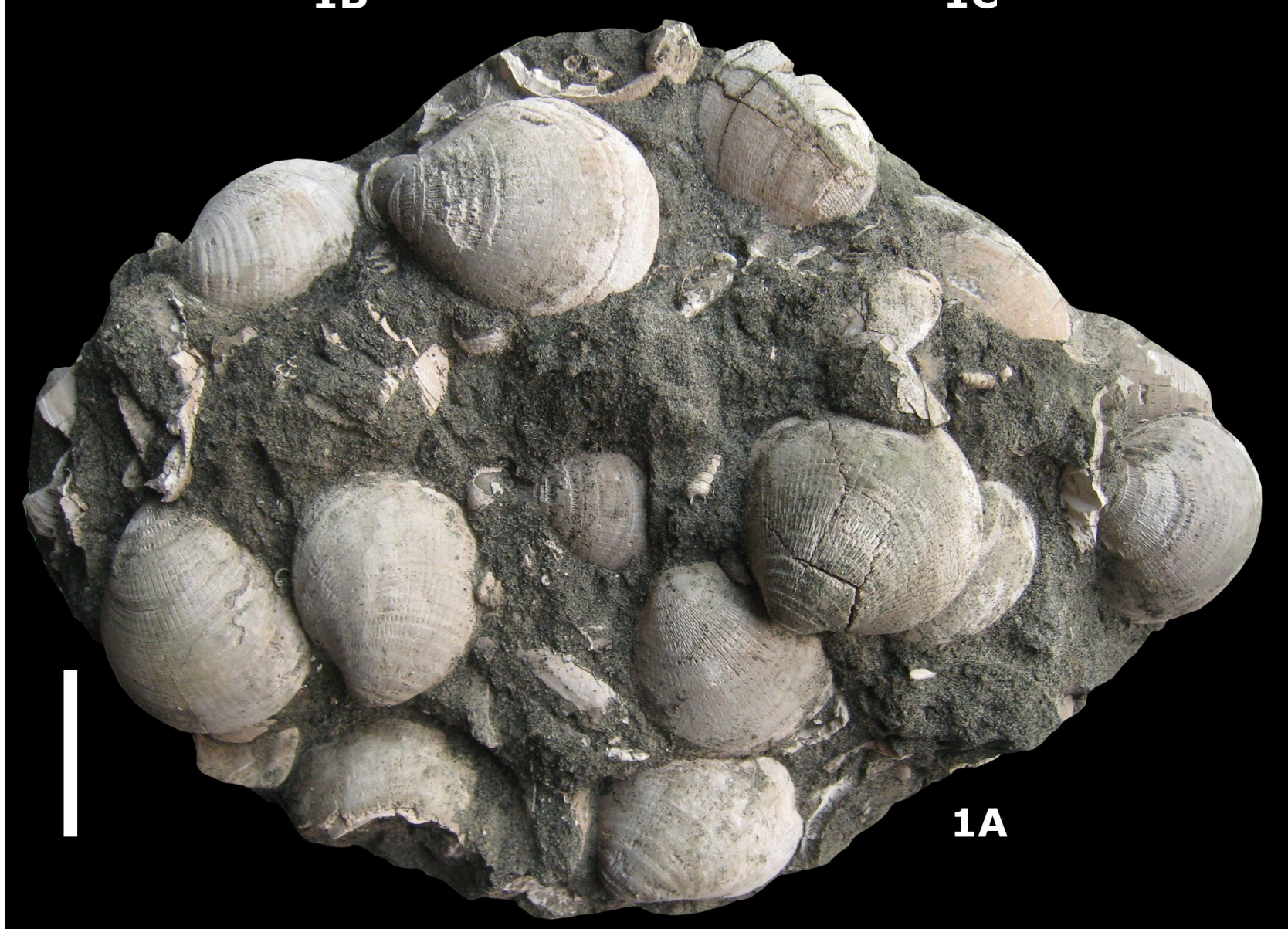

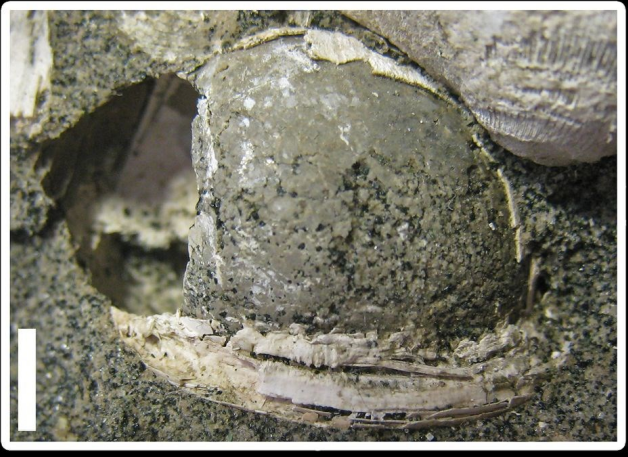

$1 \mathrm{D}$

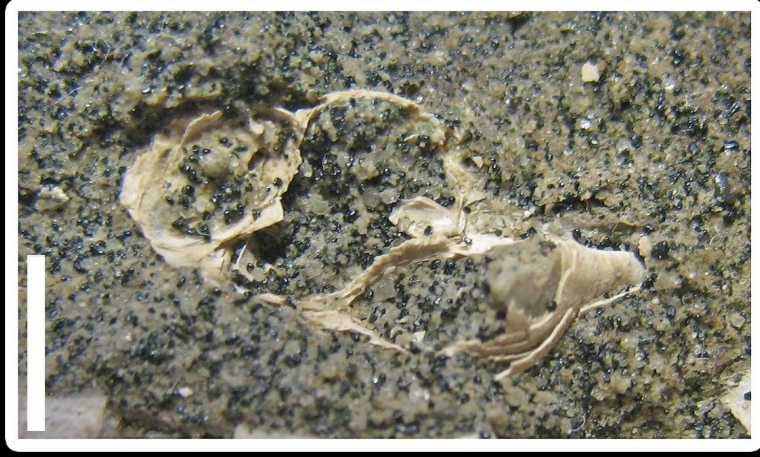

$1 E$

Plate 5. Palaeontology and taphonomy of the sandstone horizon (Kiel Sand Member). Lithification IRSNB 7680. Argenta unit 6. Dimensions : $37 \mathrm{~cm}$ x $26 \mathrm{~cm}$ x $10 \mathrm{~cm}$. 1A. Top view, dominated by Glycymeris baldii Glibert \& Van de Poel, 1965 in convex up orientation; Glycymeris valve with Maeandropolydora borings (left side). At the top, the umbonal region of a Glycymeris shows its reticulate pattern by abrasion. Scale bar 50 mm. 1BC. Detail of top view: Haustator eryna (d'Orbigny, 1852). Scale bar $5 \mathrm{~mm}$. 1D. Detail of top view: cast of Echinophoria cf. bicoronata (Beyrich, 1854). Scale bar $5 \mathrm{~mm}$. 1E. Detail of top view: a large Turridae. Scale bar $5 \mathrm{~mm}$ 


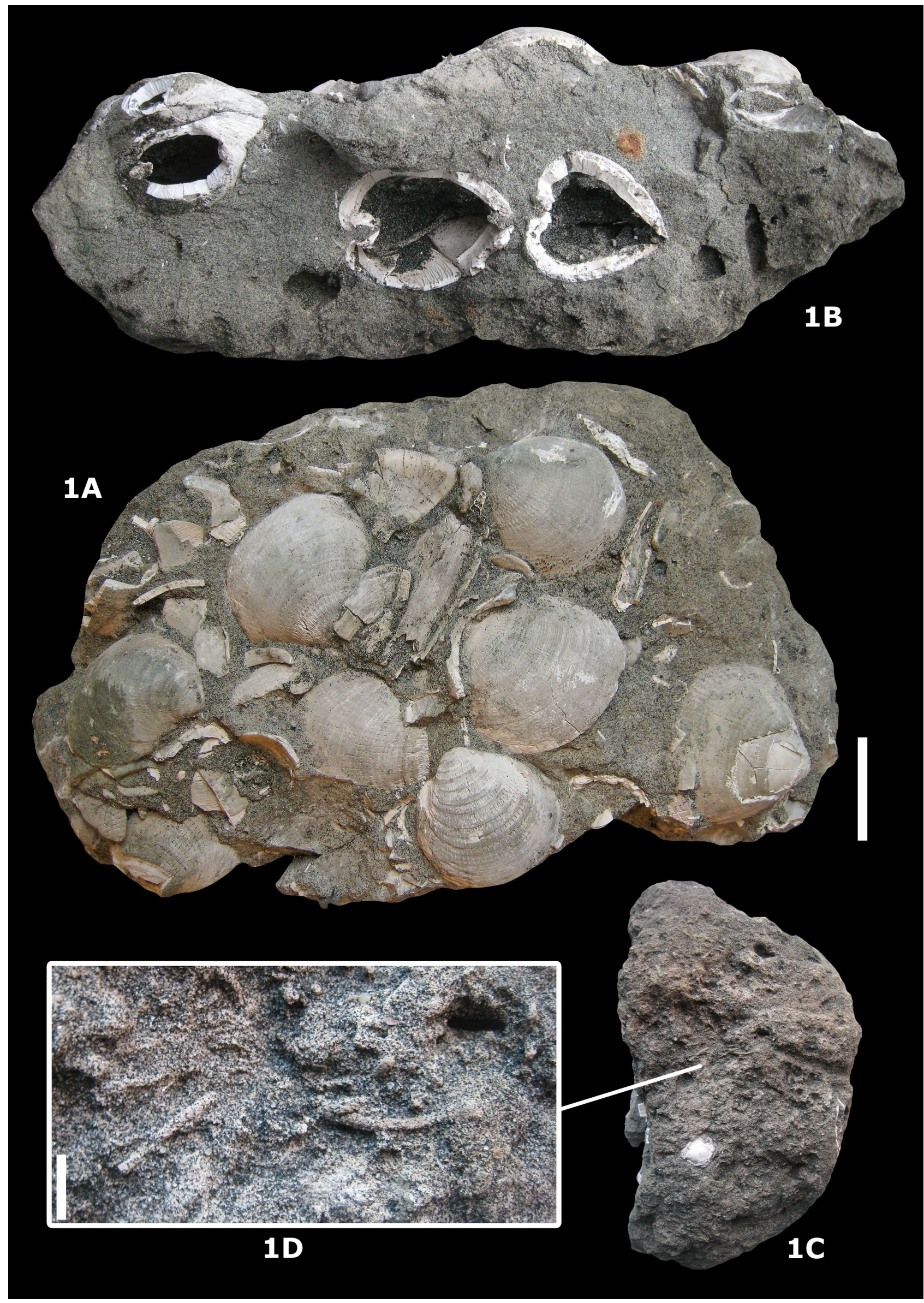

Plate 6. Palaeontology and taphonomy of the sandstone horizon (Kiel Sand Member). Lithification IRSNB 7681. Argenta unit 6. Dimensions: $38 \mathrm{~cm} \times 21 \mathrm{~cm} \times 13 \mathrm{~cm}$. 1A. Top view, dominated by Glycymeris baldii Glibert \& Van de Poel, 1965 in convex up orientation and two large fragments of Cytrodaria angusta (Nyst \& Westendorp, 1839). Scale bar $50 \mathrm{~mm}$. 1B. Lateral view. Some large bivalved Glycymeris trapped in the cemented matrix, filled with loose glauconitic sand. 1C. Bottom view. 1D. Detail of bottom view: cemented polychaet traces. Scale bar $10 \mathrm{~mm}$. 


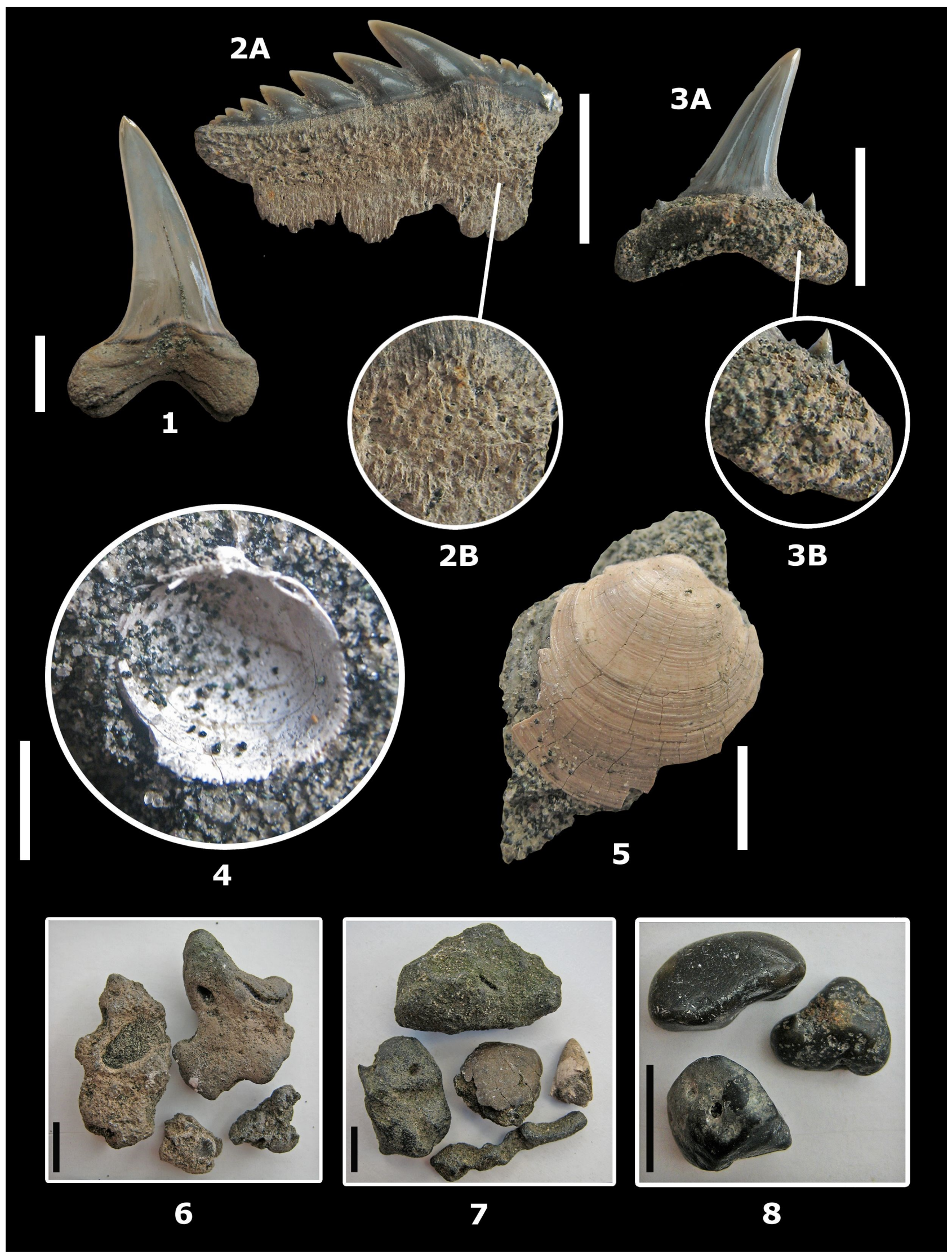

Plate 7. Palaeontology and taphonomy of the Kiel Sand Member. 1. Upper anterior tooth of Isurus oxyrinchus Rafinesque, 1810. Kiel Sand Member, Glycymeris-Cyrtodaria horizon, Argenta unit 4. Coll. SE. Scale bar $10 \mathrm{~mm}$. 2. A. Lower lateral tooth of Notorynchus primigenius (Agassiz, 1835). B. Detail of bioerosion on the root. Kiel Sand Member, Glycymeris-Cyrtodaria horizon, Argenta unit 4. Coll. SE. Scale bar 10 mm. 3. A. Upper lateral tooth of Araloselachus vorax (Le Hon, 1871). B. Detail of in situ brown-grey phosphatic concretion covering the root. Kiel Sand Member, Glycymeris-Cyrtodaria horizon, Argenta unit 4. Coll. SE. Scale bar $10 \mathrm{~mm}$. 4. Laevicardium subturgidum (d'Orbigny, 1852). Kiel Sand Member, sandstone horizon, Argenta unit 6. Coll. SE. Scale bar $5 \mathrm{~mm}$. 5. Diplodonta cf. rotundata (Montagu, 1803). Kiel Sand Member, sandstone horizon, Argenta unit 6. Coll. SE. Scale bar $5 \mathrm{~mm}$. 6. Brown-grey phosphatic concretions. Kiel Sand Member, Cordiopsis horizon, Argenta unit 8. Coll. BGD. Scale bar $10 \mathrm{~mm}$. 7. Black phosphatic concretions. On the right, a fragment of Amalda obsoleta (Brocchi, 1814) with an in situ phosphatised internal cast. Antwerpen Sand Member, Haustator eryna phosphatic horizon, Argenta unit 12. Coll. BGD. Scale bar 10 mm. 8. Black, rounded pebbles. Kiel Sand Member, Glycymeris-Cyrtodaria horizon, Tweelingenstraat unit 2. Coll. BGD. Scale bar $10 \mathrm{~mm}$. 